E

51

.N42Z

v. 6

NMAI

\title{
TURQUOIS MOSAIC ART IN ANCIENT MEXICO
}

\author{
BY \\ MARSHALL H. SAVILLE
}

NEW YORK

MUSEUM OF THE AMERICAN INDIAN

HEYE FOUNDATION

I 922 


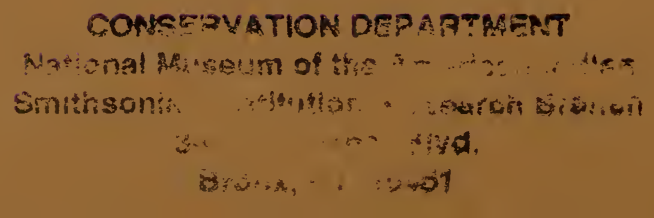

COHCEPYATION DEPARTHENT

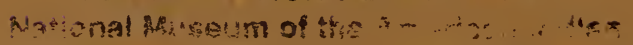

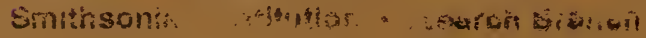

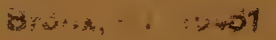$$
1
$$

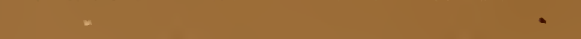


CONTRIBUTIONS

FROM THE

MUSEUM OF THE AMERICAN INDIAN

HEYE FOUNDATION

VOLUME VI 



\section{TURQUOIS MOSAIC ART IN ANCIENT MEXICO}






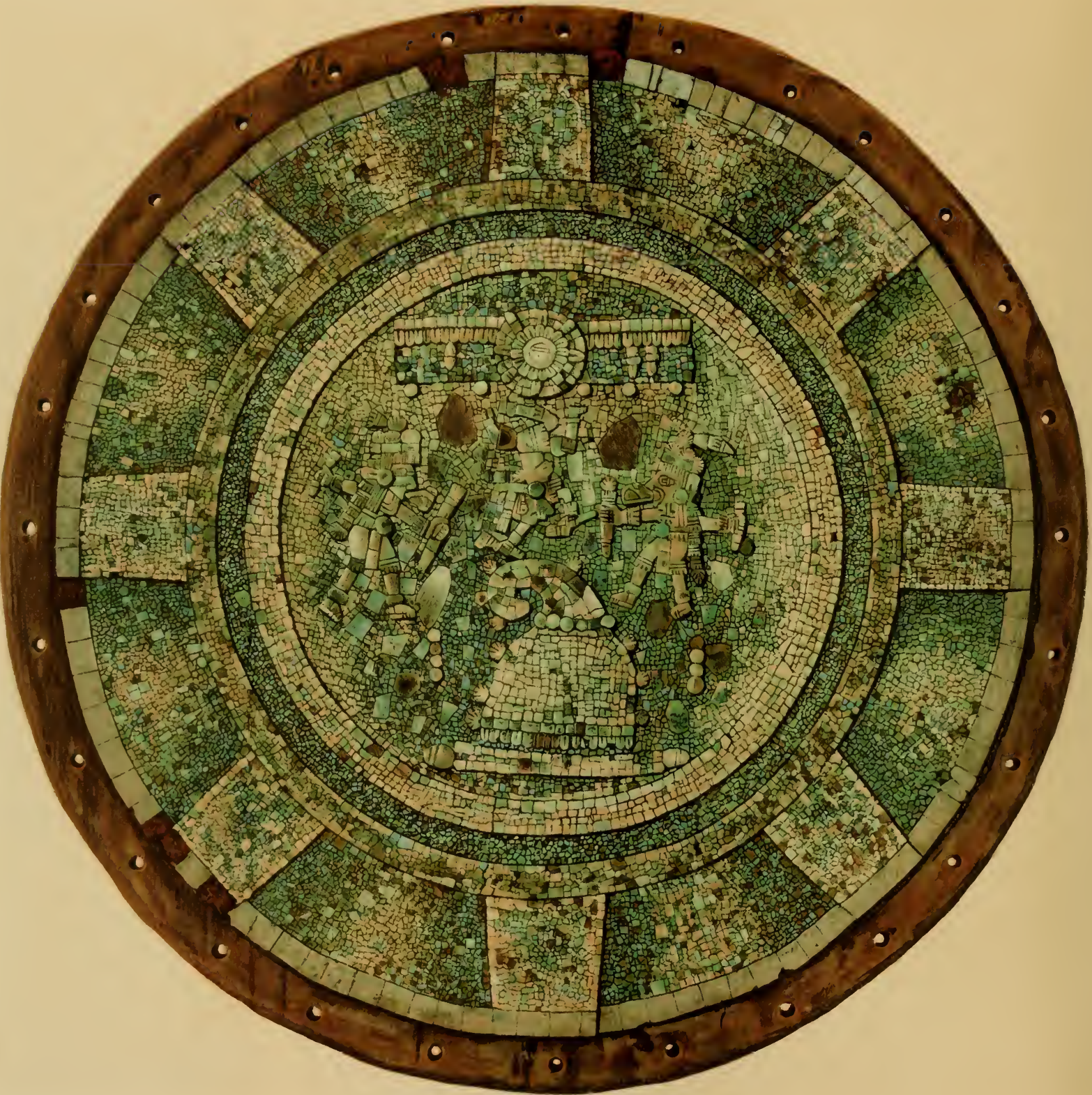

SHIELD OF WOOD WITH MOSAIC DECORATION

MUSEUM OF THE AMERICAN INDIAN HEYE FOUNDATION, NEW YORK 


\title{
TURQUOIS MOSAIC ART IN ANCIENT MEXICO
}

\author{
BY \\ MARSHALL H. SAVILLE
}

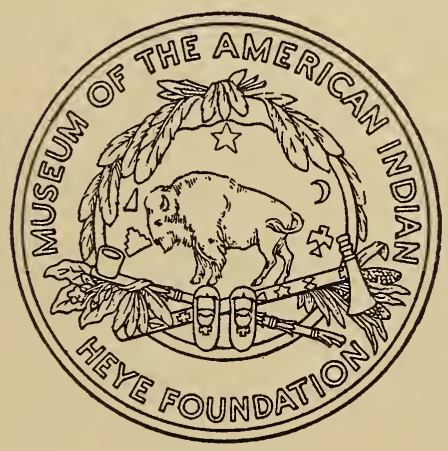

NEW YORK

MUSEUM OF THE AMERICAN INDIAN

HEYE FOUNDATION

I 922 
CONDÉ NAST PRESS GREENWICH, CONN. 


\section{GEORGE GUSTAV HEYE}

In appreciation of his long-continued interest in all that pertains to the study of the aboriginal race of . America, which has reached fruition in the opening of the

Museum of THE AMERICAN INDIAN

Heye Foundation

this volume is dedicated by the author and the staff of the Museum 



\section{PREFACE}

THE writer has undertaken the present study of Mexican Turquois Mosaics in honor of the approaching opening to the public of the Museum of the American Indian, Heye Foundation, the only institution devoted exclusively to the study of the aboriginal American peoples ever established; and the proximate International Congress of Americanists to be held at Rio de Janeiro this summer. Owing to lack of time it has been impossible to obtain new photographic illustrations of all the specimens of mosaic-work in European museums, but the author desires to express his thanks to T. A. Joyce, Esq., for his courtesy in furnishing photographs of the examples in the British Museum. To Dr. Franz Heger, of the State Natural History Museum, Vienna, we are under deep obligations for photographs and description of the interesting Xolotl figure preserved in that Museum. Dr. S. K. Lothrop has kindly had photographs made of the objects of this class in the Prehistoric and Ethnographic Museum in Rome, and has made certain valuable observations concerning them. To Drs. A. M. Tozzer and H. J. Spinden special acknowledgment is due for their generous permission to illustrate the mosaics from Chichen Itza, thus anticipating their own description of the objects in the work now being prepared regarding one of the most important discoveries ever made in ancient America. The fine drawings are from the pen of William Baake, and the beautiful plates represent the best efforts of the Heliotype Company. Finally must be acknowledged the characteristic generosity of one of the trustees of the Museum, James B. Ford, Esq., who has made it possible for us to publish this paper, and to whom the Museum is indebted for its acquisition of the precious collection of Mexican mosaics which are now described for the first time. 

CONTENTS

Preface ....... . . . . . . . . . ix

INTRODUCTION . . . . . . . . . . . . . . . . . . I I

Earliest Historical Accounts of Turquois Mosaic IN Mexico . . . . . . . . . . . . . . 3

The Grijalva Expedition, I5I $\ldots \ldots$

Loot obtained by Cortés, I5I9-I525 . . . . . . . 8

Tribute of Mosaic Paid to the Aztec Rulers . . . 22

SOURCE OF TURQUOIS . . . . . . . . . . . . . . . 27

The Aztec Lapidaries and Their Work . . . . . . 29

Objects Decorated with Mosaic . . . . . . . . . 40

Existing Specimens of Mosaic . . . . . . . . . . . 47

Minor Examples . . . . . . . . . . . . . . . . . . 48

Chichen Itza Specimens . . . . . . . . . . . . 55

Major Examples . . . . . . . . . . . . . . . . 59

Helmet . . . . . . . . . . . . . . . . 60

Masks . . . . . . . . . . . . . . . 60

Skull Masks . . . . . . . . . . . . . . . . . 67

Shields . . . . . . . . . . . . . . . . . . 68

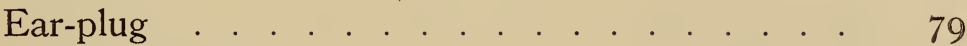

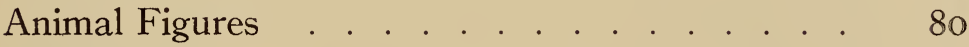



Knife Handles . . . . . . . . . . . . . . . . . 82

Human Femur Musical Instrument . . . . . . . 84

CONCLUSION . . .

Notes . . . . . . . . . . . . . . . . . . . . . . . . 92

List of Works Describing Mexican Mosaics . . . $\quad$ IO3 



\section{ILLUSTRATIONS}

\section{Plates}

PAGE

I. Wooden shield with turquois mosaic decoration.

Museum of the American Indian, Heye Foundation, New York . . . . . Frontispiece

II. Stone idol with mosaic decoration. National Museum, Mexico .. . . . . . . .

III. $a$, Wooden staff with turquois mosaic decoration, from Sacred cenote, ruins of Chichen Itza, Yucatan. Peabody Museum, Cambridge

$b$, Wooden rattle with turquois mosaic decoration, from Sacred cenote, ruins of Chichen Itza, $\mathrm{Yu}$ catan. Peabody Museum, Cambridge . . .

IV. Wooden helmet with mosaic decoration. British Museum, London . . . . . . . . . . 24

V. Wooden mask with turquois mosaic decoration. British Museum, London . . . . . . . 26

VI. Wooden mask with turquois mosaic decoration. British Museum, London . . . . . . . 28

VII. Wooden mask with turquois mosaic decoration.

Prehistoric and Ethnographic Museum, Rome

VIII. Wooden mask with turquois mosaic decoration.

Prehistoric and Ethnographic Museum, Rome

IX. Wooden mask with turquois mosaic decoration.

Museum of the American Indian, Heye Foundation, New York . . . . . . .

$\mathrm{X}$. Wooden mask with turquois mosaic decoration.

- Museum of the American Indian, Heye Foundation, New York . . . . . . . . 36 
XI. Wooden mask (fragment) with turquois mosaic decoration. Museum of the American Indian, Heye Foundation, New York

XII. Wooden mask (fragment) with turquois mosaic decoration. Museum of the American Indian, Heye Foundation, New York . . . . . . . 40

XIII. Wooden mask with mosaic decoration. Museum of the American Indian, Heye Foundation, New York . . . . . . . . . . . . . . . . 42

XIV. Wooden mask with mosaic decoration. Museum of the American Indian, Heye Foundation, New York . . . . . . . . . . . .

$\mathrm{XV}$. Wooden mask (fragment) with mosaic decoration. Museum of the American Indian, Heye Foundation, New York . . . . . . . . 46

XVI. Wooden mask formerly covered with mosaic decoration. Museum of the American Indian, Heye Foundation, New York . . . . . . . 48

XVII. Wooden mask with turquois mosaic decoration, from Honduras. Museum of the American Indian, Heye Foundation, New York . . .

XVIII. Skull mask with mosaic decoration. Ethnographical Museum, Berlin . . . . . . . . . 52

XIX. Skull mask with mosaic decoration. British $\mathrm{Mu}-$ seum, London . . . . . . . . . . . . 54

XX. Wooden shield with turquois mosaic decoration. British Museum, London . . . . . . . 56

XXI. Wooden shield with turquois mosaic decoration. State Natural History Museum, Vienna . . . 58

XXII. Back of wooden shield illustrated in P1. I. Museum of the American Indian, Heye Foundation, New York . . . . . . . . . 
XXIII. Wooden shield with mosaic decoration. Museum of the American Indian, Heye Foundation, New York . . . . . . . . . . . . . . . . 62

XXIV. Wooden shield with mosaic decoration. Museum of the American Indian, Heye Foundation, New York . . . . . . . . . . . . .

XXV. Wooden shield (fragment) with mosaic decoration. Museum of the American Indian, Heye Foundation, New York . . . . . . . . .

XXVI. Wooden shield (fragment) with mosaic decoration. Museum of the American Indian, Heye Foundation, New York . . . . . . . . . 68

XXVII. Wooden shield (fragment) with mosaic decoration. Museum of the American Indian, Heye Foundation, New York . . . . . . . 70

XXVIII. Wooden shield (fragment) with mosaic decoration. Museum of the American Indian, Heye Foundation, New York . . . . . . . 72

XXIX. Wooden shield (fragment) with mosaic decoration. Museum of the American Indian, Heye Foundation, New York . . . . . . . . . .

XXX. Wooden ear-plug with mosaic decoration. $\mathrm{Mu}-$ seum of the American Indian, Heye Foundation, New York . . . . . . . . . . . . . 76

XXXI. Wooden head with head-piece, with mosaic decoration. National Museum, Copenhagen . . . 78

XXXII. $a$, Wooden jaguar head with mosaic decoration. Ethnographical Museum, Berlin

$b$, Wooden head of animal and human face in jaws with mosaic decoration. National $\mathrm{Mu}$ seum, Copenhagen . . . . . . . . . .

XXXIII. $a$, Wooden head of animal with mosaic decoration. State Natural History Museum, Vienna

$b$, Wooden head of monkey with mosaic decoration. British Museum, London . . . . . . 78 
XXXIV. $a$, Wooden two-headed jaguar figure with mosaic decoration. Ethnographical Museum, Berlin

$b$, Wooden bird's head with mosaic decoration. Museum, Gotha . . . . . . . . . 78

$\mathrm{XXXV}$. Wooden animal figure on haunches with mosaic decoration. British Museum, London . . . 78

XXXVI. Wooden double-headed snake figure with mosaic decoration. British Museum, London . . . 80

XXXVII. Wooden figure of Xolotl god with mosaic decoration. State Natural History Museum, Vienna

XXXVIII. Flint knife with wooden handle with mosaic decoration. British Museum, London . . . . 82

XXXIX. $a$, Wooden knife handle with mosaic decoration. Prehistoric and Ethnographic Museum, Rome $b$, Wooden knife handle with mosaic decoration. Prehistoric and Ethnographic Museum, Rome

XL. Human femur musical instrument with mosaic decoration. Prehistoric and Ethnographic Museum, Rome . . . . . . . .

\section{Text Figures}

I. Bowl filled with turquois. After Tribute Roll of Montezuma .............. 2

2. Ten masks of turquois. After Tribute Roll of Montezuma 24

3. Small bag filled with turquois. After Tribute Roll of Montezuma . . . . . . . . . . . 25

4. Shields with turquois mosaic decoration. After Tribute Roll of Montezuma - * * * *

5. Serpent scepter with turquois mosaic decoration. After Sahagun, manuscript of the Real Palacio, Madrid . . 
6. a, Gold crown with turquois mosaic decoration. After Sahagun, manuscript of the Real Palacio, Madrid $b$, Gold crown. After Tribute Roll of Montezuma . . .

7. Pottery disc with hematite mosaic decoration, from Cuilapa, Oaxaca. American Museum of Natural History, New York . . . . . . . . . . . . . 5

8. Gold shield breast ornament with turquois mosaic decoration, from Yanhuitlan, Oaxaca. National Museum, Mexico . . . . . . . . . . . . .

9. Wooden object (fragment) with turquois mosaic decoration, from Sacred cenote, ruins of Chichen Itza, Yucatan. Peabody Museum, Cambridge .... . . .

Io. Wooden object (fragment) with turquois mosaic decoration, from Sacred cenote, ruins of Chichen Itza, Yucatan. Peabody Museum, Cambridge . . . .

II. Rattle of the god Xipe Totec. After Sahagun, manuscript of the Real Palacio, Madrid . . . . . . . . . 58

I2. $a, b, c$, Crowns with mosaic decoration, from sculptured wall, Temple of the Jaguars, ruins of Chichen Itza, Yucatan. After Maudslay . . . . . . . . . $5^{8}$

I3. Mask with mosaic decoration, from sculptured wall, Temple of the Jaguars, ruins of Chichen Itza, Yucatan. After Maudslay . . . . . . . . . . . . .

I4. Mask with mosaic decoration, from sculptured wall, Temple of the Jaguars, ruins of Chichen Itza, Yucatan. After Maudslay . . . . . . . . . .

I5. Mask of wood with turquois mosaic decoration. Prehistoric and Ethnographic Museum, Rome. After Pigorini

I6. God Paynal with shield decorated with turquois mosaic. After Sahagun, manuscript of the Real Palacio, Madrid

I7. God Paynal with shield decorated with turquois mosaic. After Sahagun, Florentine manuscript . . . . . 
18. Glyphs of the town of Culhuacan. After Codex Telleriano Remensis . . . . . . . . . . . . . . . 74

19. Knife handle of wood with turquois mosaic decoration. Prehistoric and Ethnographic Museum, Rome. After Pigorini 


\section{TURQUOIS MOSAIC ART IN ANCIENT MEXICO}

BY MARSHALL H. SAVILLE

\section{INTRODUCTION}



$\mathrm{NE}$ of the tragedies of the discovery of the New World was the abrupt and summary blotting out of the flourishing and still advancing civilization of the Aztec and other Mexican tribes. Had their complete conquest and subjection been delayed a few decades they in all probability would have developed a written phonetic language. Their intellectual abilities are evidenced by a study of the intricate calendar system, and the picture and hieroglyphic records which survive. The triumphs of their architectural attainments are well known, and may be investigated in the numerous monuments and buildings in the ruined cities scattered throughout Mexico. They had made notable strides toward civilization in certain of the minor fine arts. Ignorant of glass and of glazed pottery, they nevertheless developed the ceramic art to a high degree of excellence. Their inventive genius and technical skill were manifest in their goldsmith's art. ${ }^{1}$

Without the knowledge of iron, in the working of hard precious and semi-precious stones into idols and personal ornaments, their craftsmanship was equal to that of the best lapidaries of Europe at the beginning of the sixteenth century. In the lapidarian art they had advanced so far as to fashion and adorn many objects with designs, both geometric and realistic, in stone mosaic, employing turquois chiefly for this purpose, but also making use of other stones-marcasite and shell. But the supreme esthetic achievement of the Aztecs was the production of a class of mosaics in which they used tiny bits of colored feathers instead of stones in making the designs. 
This unique art was employed in adorning objects for personal use, for warfare, or for priestly ceremonies. The patterns were produced by applying the tiny bits of feathers with glue either directly on wood or on wooden objects covered with skin or with native paper. From descriptions of feather mosaics in the writings of early chroniclers, and from a study of the handful of specimens which have escaped the ravages of time, it is evident that this art reached the highest artistic level attained by any of the aboriginal tribes of America.

We will not enter into a discussion of feather mosaics at this time, but will consider primarily the parallel art of turquois mosaic. Aside from the numerous historical notices contained in the early chronicles and in the inventories of the loot of the Aztecs sent to Europe by Cortés, there is little of this art upon which to base a careful study that has survived. It is one of the most interesting and highly developed arts of ancient America, but it was practised by only a few tribes. Apart from the Mexican region where turquois mosaic was most highly developed, excellent examples have been found with other ancient remains of the Pueblos of Arizona and New Mexico, and incrusted objects have also been found with ancient burials on the coast of Peru, indicating a somewhat similar technique though far less skill in application. The materials usually employed in Mexico were turquois, jadeite, malachite, quartz, beryl, garnet, obsidian, marcasite, gold, bits of red and other colored shell, and nacre. The base upon which the incrustation was laid was wood, stone, gold, shell, pottery, and possibly leather and native paper, the mosaic being held in place by means of a tenacious vegetal pitch or gum, or a kind of cement. 


\section{EARLIEST HISTORICAL ACCOUNTS OF TURQUOIS MOSAIC IN MEXICO}

\section{The Grijalva Expedition, I5I8}

THE first knowledge received by Europeans of the existence of turquois mosaic objects among the Mexicans was by members of the expedition sent out from Cuba by the governor, Diego Velásquez, during the spring of $\mathrm{I}_{5} \mathrm{I} 8$, under the command of Juan de Grijalva. After reaching the shores of Yucatan near the island of Cozumel, the party coasted the Yucatan peninsula, reaching the territory of the present State of Campeche, which had been discovered the previous year by Francisco Hernández de Córdoba. Proceeding westward along unknown lands, they reached a great river in the State of Tabasco, to which the name of the commandant was given, and it is still known as Rio de Grijalva. Here, according to some accounts, the expedition obtained the first specimens of turquois mosaic. We shall consider this point later. Leaving the Rio de Grijalva they went westward and arrived at the site of the present city of Vera Cruz, where they obtained by barter with the Indians a considerable treasure, including some objects of turquois mosaic, which Grijalva decided to send immediately to the governor in Cuba with a report of his discoveries up to that time. Consequently, on June 24, I5I8, one of Grijalva's captains, Pedro de Alvarado, set out on the return voyage to Fernandina (Cuba), while Grijalva himself continued the exploration of the eastern coast of Mexico.

The provenience of the treasure obtained by Grijalva on this first expedition of discovery to the coasts of Tabasco and Vera Cruz in 1518 is not at all clear from the accounts of this voyage in the writings both of the eye-witnesses themselves and of those who shortly afterward wrote of the conquest from the reports of the participants in the events. It has been 
generally assumed that Grijalva obtained mosaic objects from the Indians of Tabasco; this is specifically stated by both Oviedo and Gomara, who recorded detailed accounts of the Grijalva expedition. The account by Oviedo ${ }^{2}$ is even more extended and valuable than the narrations of the eye-witnesses, namely, Juan Díaz ${ }^{3}$ the chaplain, and the redoubtable Bernal Díaz. Oviedo states that his account is from the report forwarded to the King of Spain by the governor Velásquez, who sent out the expedition from Cuba. Gomara, who for a time was chaplain of Cortés in Spain, never visited the New World, but had access to the various reports sent to Spain regarding the conquest.

Unfortunately in the writings of the eye-witnesses no detailed descriptive lists are to be found relating just what pieces of mosaic-work were obtained by Grijalva from the Mayan Indians of Tabasco and the people of the coast of the present State of Vera Cruz. The extended account given by Oviedo recites the voyage from day to day and the character of various objects received from the Tabasco Indians, followed by the list of specimens obtained from the Mexican Indians near the Isla de Sacrificios, Vera Cruz. We will quote from these lists later. Gomara's list is quite extended. In the first part of his Historia de las Indias he describes various articles procured by Grijalva from the Indians at the mouth of the river in Tabasco, to which his name was applied, followed in turn by the inventory of objects obtained at San Juan de Ulua, Vera Cruz. In the second part of his history, the Conquista de Mexico, he gives only a single long inventory of the barter obtained, as he says, "from the Indians of Potonchan [Tabasco], San Juan de Ulua, and other places of that coast." It seems highly probable, however, that such interesting and valuable loot must have been accompanied with an inventory when it was sent to Spain late in 1518 or early in 1519 by Governor Velásquez. Oviedo mentions seeing the things, apparently in Barcelona, in May 1519 . It is possible that both Oviedo and Gomara may have had access to such an inventory, or if not, 
they wrote their own descriptions of the objects after seeing them.

Bernal Díaz, who accompanied both Grijalva and Cortés to Mexico, wrote his history nearly fifty years after the stirring events of the discovery and conquest. He was a prejudiced writer, and seems to have been largely animated in his old age to tell the story of the conquest primarily to refute many of the statements of Gomara. Bernal Díaz writes bluntly at the very outset of his invaluable history, which he calls the "True History," that he speaks "here in reply to all that has been said and written by persons who themselves knowing nothing, have received no true account from others of what really took place, but who nevertheless now put forward any statements that happen to suit their fancy." While not describing the treasure obtained by Grijalva, he mentions "some gold jewels some (of which) were diadems and others were in the shape of ducks like those of Castile, and other jewels like lizards, and three necklaces of hollow beads, and other articles of gold not of much value, for they were not worth more than two hundred pesos." ${ }^{4}$ These he states were obtained from the Indians of Potonchan. For some reason he apparently was not greatly impressed either by the technical excellence or by the esthetic beauty of the objects procured by barter from the vicinity of the present city of Vera Cruz; he simply writes that the Spaniards were engaged for six days in trading with the Indians and got more than sixteen thousand dollars' worth of jewelry of low-grade gold worked into various forms. He then says: "This must be the gold which the historians Gomara, Yllescas, and Jovio say was given by the natives of Tabasco, and they have written it down as though it were true, although it is well known to eye-witnesses that there is no gold in the province of the Rio de Grijalva or anywhere near it, and very few jewels." 5 Torquemada wrote in later years to the same effect.

In none of the accounts by the participants of this expedition are mosaic pieces specifically mentioned. The chaplain 
of Grijalva's fleet, Juan Díaz, states merely that they were given "a mask of gold beautifully wrought, and a little figure of a man with a little mask of gold, and a crown of gold beads with other jewels and stone of various colors." This report was first printed in Venice, March 3, 1520, appearing in Italian as an appendix to the Itinerario of Ludovico de Varthema.

An anonymous independent relation in Italian of this voyage seems to have been printed at Venice in the same year under the title Littera Mãdata della Insula de Cuba, etc., the copy in the Marciana Library, Venice, being the only one known. From a photostat copy of the Italian we are able to present a translation of the mention of these objects, somewhat similar to that given by Juan Díaz. The Littera Mãdata states that the Spaniards obtained "a mask of gold, and the figure of a man all of gold, seemingly of the age of twelve, and a fan of gold, and other jewels of divers colors." 6

Another anonymous early printed report, in Latin, without date or place of printing, affords practically the same information as that contained in the Itinerario of Juan Díaz and in the Littera Mãdata. ${ }^{7}$

The earliest printed information regarding the Grijalva voyage in which mosaic objects are specifically noted is in Peter Martyr's De. Nvper Sub D. Carolo Repertis Insulis, printed in Basle in $152 \mathrm{I}$. In speaking of the valuable objects obtained by Grijalva in Coluacan (Vera Cruz), and sent to Spain, he mentions that "the cacique brought a small golden statue of a man, also a gold fan, and a mask beautifully wrought and decorated with stones." 8 It will be observed that these objects correspond with those mentioned in the reports noted above, only that Peter Martyr speaks of the decoration of the mask with stones. With the exception of this note by Peter Martyr, who saw the objects in Spain, there is, as we have said, no special statement regarding mosaic-work to be found in the earliest known printed accounts of the Grijalva voyage. In 1535 the great work of Oviedo was first published, and here we find the following itemized description of pieces of mosaic- 
work, said to have been obtained from the Indians of Potonchan, Tabasco. ${ }^{9}$

Another mask covered from the nostrils upward with well set mosaic-work of stones resembling turquoises, and from the nostrils downward with a thin plate of hammered gold.

Another mask resembling the first, but the stones were placed from the eyes upward, and below them there were thin plates of beaten gold over wood, the ears being of turquois mosaic-work.

Another mask made with bands or rods of wood, two of the strips being covered with mosaic-work, and the remaining other three with thin beaten gold.

A thin disc with a figure of a cemi or devil, covered above with beaten gold-leaf, and in other parts were scattered some stones.

A tablet of wood like the headstall of a horse in armor, covered over with thin gold-leaf, with some strips of black stones well set between the gold.

The head of a dog covered with stones, and very well made.

From Ulua in Vera Cruz these mosaic pieces are noted:

Two masks of small stones like turquois set over wood like mosaic, with some spangles of gold in the ears.

Two guariques of blue stones set in gold, each having eight pendants of the same.

A mask of stone mosaic-work.

In the work of Gomara, printed in 1553, appears also an extended account of this barter. ${ }^{10}$

Seler ${ }^{11}$ and Lehmann ${ }^{12}$ believe that most of the mosaic objects "apparently came from the eastern provinces, i.e., Tabasco." Relying on the authority of both Oviedo and Gomara, Lehmann further uses in his discussion the original Nahuatl text of Sahagun in the Florentine manuscript copied and translated by Seler. In this section of Sahagun's work relating to the attributes of the Mexican deities occurs the paragraph, "In jtlatquj Quetzalcoatl coa-xaiacatl xiuhticatl achivalli, quetzalapanecaiotl," which Lehmann renders, "The Quetzalcoatl dress, the snake-mask with turquois work, the feather ornament of the people of Quetzalapan ('Tabasco)." ${ }^{13}$ 
But there is no mention in early chronicles or on early maps of any town in this region bearing the name Quetzalapan, and Torquemada in giving an account of some of the wars of Montezuma writes that "during the twelfth year of his reign (which was in 1514), his armies set out for the land of the Chichimecas, and entered the Huaxteca, subduing those of Quetzalapan." ${ }^{14}$ Other places bearing the name Quetzalapan were in the present states of Morelos, Guerrero, and Colima. ${ }^{15}$ In recounting the episode of the conquest of this town, Clavijero writes explicitly that "Montezuma sent out an army in I5I2 to the north against the Quetzalapanecas and conquered them with but little loss." ${ }^{16}$ Hence the place mentioned by Sahagun would seem to have been in Vera Cruz, and probably the region of Huaxteca or Cuexteca, for the Aztecs had considerable communication with this territory.

\section{Loot ObTained By CoRTÉs, I519-1525}

But the treasures of native art secured by the Grijalva expedition were insignificant by comparison with the enormously valuable loot obtained the next year (1519) by Cortés. It is not necessary in this study of Mexican mosaics to enter into the details of the expedition which set out from Cuba to follow the discoveries of Grijalva and which resulted in the conquest of Mexico. This has been done many times, but in the main most weight is given to the writings of the Spanish participants and to the early chroniclers. We have already studied in considerable detail the accounts of the art objects sent to Spain by Cortés, as contained in these early writings, and especially the inventories which accompanied the shipments of objects sent to Europe by the conqueror. Let us quote here merely what we wrote in presenting a summary of the events that occurred when Cortés first landed on the coast of Vera Cruz.

After the arrival of the Spaniards on the coast of Vera Cruz, the Indians were not long in ignorance of the consuming thirst of the conquerors for gold. In order to placate the formidable strangers 
with childlike confidence that by giving them their wish the invasion of his dominions would be averted, Montezuma sent rich presents to Cortés through Tendile (Teuhtlile), governor of Cuetlaxtla (the modern Cotastla), which was then subject to the Aztecs. When all this treasure thus brought together was ready to be sent to Spain, with the report of the voyage, an inventory or list of the objects was drawn up and despatched with two special messengers, Alonso Portocarrero and Francisco de Montejo, who were charged to deliver the treasure to the King. These valuable gifts have been briefly described by several members of the expedition who saw them before they left Mexico, and on their receipt in Spain they were described by various other chroniclers.

From the inventory, which we translated, we select the items relating to objects ornamented with stone mosaic.

Item: two collars of gold and stone mosaic-work (precious stones) ....

Another item: a box of a large piece of feather-work lined with leather, the colors seeming like martens, and fastened and placed in the said piece, and in the center (is) a large disc of gold, which weighed sixty ounces of gold, and a piece of blue stone mosaic-work a little reddish, and at the end of the piece another piece of colored feather-work that hangs from it.

Item: a miter of blue stone mosaic-work with the figure of monsters in the center of it, and lined with leather which seems in its colors to be that of martens, with a small (piece) of feather-work which is, as the one mentioned above, of this said miter.

Item: . . . a scepter of stone mosaic-work with two rings of gold, and the rest of feather-work.

Item: an armlet of stone mosaic-work. . . .

Item: a mirror placed in a piece of blue and red stone mosaicwork, with feather-work stuck to it, and two strips of leather stuck to it. ... .

Item: some leggings of blue stone mosaic-work, lined with leather, of which the colors seem like martens; on each one of them (there are) fifteen gold bells.

Item: two colored (pieces of) feather-work which are for two (pieces of) head armor of stone mosaic-work. . . . 
More: two guariques (ear ornaments) of blue stone mosaic-work, which are to be put in the head of the big crocodile.

More: another head armor of blue stone mosaic-work with twenty gold bells which hang pendent at the border, with two strings of beads which are above each bell, and two guariques of wood with two plates of gold.

Item: another head armor of blue stone mosaic-work with twenty-five gold bells, and two beads of gold above each bell, that hang around it with some guariques of wood with plates of gold, and a bird of green plumage with the feet, beak, and eyes of gold.

Moreover: sixteen shields of stone mosaic-work with their colored feather-work hanging from the edge of them, and wide-angled slab with stone mosaic-work with its colored feather-work, and in the center of the said slab, made of stone mosaic-work, a cross of a wheel which is lined with leather, which has the color of martens.

Again: a scepter of red stone mosaic-work, made like a snake, with its head, teeth, and eyes (made) from what appears to be mother-of-pearl, and the hilt is adorned with the skin of a spotted animal, and below the said hilt hang six pieces of small featherwork.

Item: a piece of colored feather-work which the lords of this land are wont to put on their heads, and from it hang two ear-ornaments of stone mosaic-work with two bells and two beads of gold, and above a feather-work of wide green feathers, and below hang some white, long hairs. ${ }^{17}$

Peter Martyr, who saw the specimens in Spain shortly after they arrived, speaks of "certain miters beset with precious stones of divers colors, among which some are blue, like unto sapphires." Also "two helmets garnished with precious stones of a whitish blue color: one of these is edged with bells and plates of gold, and under every bell two knobs of gold. The other, beside the stones wherewith it is covered, is likewise edged with xxv golden bells and knobs: and hath on the crest, a green bird with the feet, bill, and eyes of gold." 18

Las Casas describes "a helmet of plates of gold, and little bells hanging (from it), and on it stones like emeralds." Also "many shields made of certain thin and very white rods, inter- 
mingled with feathers and discs of gold and silver, and some very small pearls, like misshapen pearls." 19

These are some of the statements of early Spaniards. Let us now consider what the Indians have said about the treasure given by Montezuma to Cortés at that time. Our best source of information is the great Historia composed by Fray Bernardino de Sahagun, who spent many years in the valley of Mexico gathering information at first-hand from intelligent Indians. This was shortly after the conquest when the natives still retained vivid recollections of the fall of their country. Without this work the history of ancient Mexico, and of the customs and traditions of the Indians, could not be written.

We must not lose sight of the fact that Montezuma, for a number of reasons which we need not relate here, expected the "second coming" of the culture-hero Quetzalcoatl, the great beneficent god of the Aztecs. This myth was one of the several causes that led to the comparatively easy conquest of a numerous and warlike people by the Spaniards. We have translated several chapters of Sahagun's Historia relating to the first coming of the Christians to the coast of Mexico, which contain a description of some of the gifts sent by Montezuma to Cortés, while he still believed the Spanish conqueror to be the great god Quetzalcoatl. It is really a report transmitted to us from the Aztecs, and is a most fascinating chapter of the history of the conquest of Mexico. ${ }^{20}$

CHAPTER II. Of the first (Spanish) ships which arrived at this land, said to have been those of Juan de Grijalva.

The first time that ships appeared on the coast of New Spain, the captains of Montezuma, who were called calpixques, who were near the coast, at once went to see what it was that had come, never having seen ships; one of whom was the calpixque of Cuextecatl, named Pinotl: other calpixques went with him, one of whom, named Yaotzin, lived in the town of Mictlanquauhtla, another named Teozinzocatl resided in the town of Teociniocan, another named Cuitlalpitoc was not a calpixque but the servant of one of these calpixques, and principalejos, and another principalejo named 
Tentlil. These went to see what the thing was, and carried some things to sell under pretence, so as to see what the thing was: they carried some rich mantles which only Montezuma, and no other (person), wore, nor had permission to wear: they entered canoes and went to the ships, saying amongst themselves, "We are here to guard this coast; it is right that we should know for a certainty what this is, in order to carry accurate news to Montezuma." They entered at once the canoes and commenced to paddle to the ships, and when they arrived near the vessels and saw the Spaniards, all kissed the prows of the ships, in sign of adoration, thinking that it was the god Quetzalcoatl that had returned, which god, as appears in the history, was already expected. Then the Spaniards spoke and said: "Who are you? . Whence have you come? From where are you?" Those who came in the canoes responded, "We have come from Mexico." The Spaniards said, "If it is true that you are Mexicans, tell us what is the name of the Lord of Mexico." They replied, "Our Lord, he is called Montezuma," and then they presented all of those rich mantles which they had brought to him who went as general of those ships, who was, as is said, Grijalva, and the Spaniards gave to the Indians some glass beads, some green and others yellow, and the Indians when they saw them were very much astonished and esteemed them greatly, and then they (the Spaniards) dismissed the Indians, saying, "Now we return to Castile, and will soon return and will (then) go to Mexico." The Indians returned to land and soon departed for Mexico, where they arrived in a day and a night, to give the news of what they had seen to Montezuma, and they brought to him the beads which had been given them by the Spaniards, and spoke to him (Montezuma) as follows: "Our Lord, we are deserving of death; hear what we have seen, and what we have done. Thou hast placed us on guard at the seashore; we have seen some gods on the sea, and went to receive them, and give them various rich mantles; look at these beads that they gave us, saying to us, 'Is it true that you are Mexicans? Look at these beads, give them to Montezuma, that he may know of us.' " And they told him all that had happened when they were with those (people) on the sea in the ships. Montezuma responded: "You have come tired and worn out; go and rest. I have received this (news) in secret, and command you not to say anything whatever about what has happened." 
Chapter III. Of what Montezuma disposed after he heard the news from those who saw the first (Spanish) ships.

As soon as he (Montezuma) heard the news from those who had come from the seashore, he ordered to be called at once the highest chief of those who were called Cuextecatl, and the others who had come with the message, and ordered them to place guards and lookouts in all the farms along the shores of the sea, the one called Naulitlantoztlan, and the other Mictlanquactla, so that they might see when those ships returned, and at once give a report. The calpixques and captains then left, and at once ordered the placing of lookouts on the said farms, and Montezuma then summoned the most confidential of his chieftains and communicated to them the news which had arrived, and showed them the glass beads which the messengers had brought, and said, "It seems to me that they are precious stones: take great care of them in the wardrobe that none of them be lost, and if any are lost, those who have charge of the wardrobe will have to pay." One year hence, in the year thirteen rabbit, those who were on guard saw ships on the sea, and at once came with great speed to give notice to Montezuma. As soon as he had heard the news, Montezuma despatched men for the reception of Quetzalcoatl, because he thought that it was him who came, because they expected him daily, and as he had received news that Quetzalcoatl had gone by sea toward the east, and the ships came from the eastward, for this (reason) they thought that it was he: he sent five of his chief lords to receive him and to present to him a great present, which he sent. Of those who went the most prominent one was called Yallizchan, the second in rank Tepuztecatl, the third Tizaoa, the fourth Vevtecatl, and the fifth Veicaznecatlheca.

CHAPTER IV. What Montezuma ordered when he learned the second time that the Spaniards had returned, this was D. Hernando Cortés.

To the above mentioned (messengers) Montezuma spoke, and said, "Look, it has been said that our Lord Quetzalcoatl has arrived; go and receive him and listen to what he may say to you with great attention; see to it that you do not forget anything of what he may say; see here these jewels which you are to present to him in my behalf, and which are all the priestly ornaments that belong to him." First a mask wrought in a mosaic of turquois; this mask had 
wrought in the same stones a doubled and twisted snake, the fold of which was the beak of the nose; then the tail was parted from the head, and the head with part of the body came over one eye so that it formed an eyebrow, and the tail with a part of the body went over the other eye, to form the other eyebrow. This mask was inserted on a high and big crown full of rich feathers, long and very beautiful, so that on placing the crown on the head, the mask was placed over the face: it had for a (central) jewel a medallion of gold, round and wide: it was tied with nine strings of precious stones, which, placed around the neck, covered the shoulders and the whole breast: they carried also a large shield bordered with precious stones with bands of gold which went from the top to the bottom of it, and other bands of pearls crossing over the gold bands from the top to bottom of it, and in the spaces left by these bands, which were like the meshes of a net, were placed zapitos (little toads) of gold. This shield had edgings in the lower part; there was attached on the same shield a banner which came out from the handle of the shield, made of rich feathers: it also had a big medallion made of mosaic-work which was fastened and girded around the loins: they carried also strings of precious stones with gold bells placed in between the stones to be tied to the ankles: they carried also a bishop's staff all decorated with turquois mosaic-work, and the crook of it was like the head of a snake turned around or coiled. They also carried sandals (cotaras) such as great lords were accustomed to wear. They also carried the ornaments or finery with which Tezcatlipoca was adorned, which was a head-piece made of rich feathers which hung down on the back almost to the waist, and was strewn all over with stars of gold. They carried also ear-ornaments of gold: they had hanging from them little gold bells and strings of little white and beautiful sea-shells. From these strings hung a piece of leather like a plastron (peto), and it was carried tied in such a manner that it covered the breast down to the waist: this plastron had strewn on it and hanging from it many little shells. They carried also a corselet of painted white cloth; the lower border of this corselet was edged with white feathers in three strips all around the border: they also carried a rich mantle the cloth of which was a light blue, and embroidered all over with many designs of a very fine blue: this mantle was worn around the waist, the (four) corners tied to the body: over this mantle was worn a medallion of turquois [work] attached to the body 
over the loins : they also carried strings of gold bells to tie around the ankles, and also white sandals (cotaras) like those the lords are wont to wear. They also carried the ornaments and decorations of the god Tlalocantecutli, which were, a mask with its feather-work, and a banner like the one above mentioned: also wide ear-ornaments of chalchivitl with snakes of chalchivites inside: and also a corselet painted with green designs, and strings or collar of precious stones, and also a medallion with which they girded the loins, like the one above described, with a rich mantle, with which they girded themselves like the one described above, and golden bells to place on the feet, and the staff like the one above described. Other ornaments which they carried were also of the same Quetzalcoatl, a miter of tiger-skin, and hanging from the miter a hood of raven's feathers: the miter also had a large chalchivitl rounded at the end, and also round ear-ornaments of turquois mosaic with a hook of gold called ecacozcatl, and a rich mantle with which he girded himself, and some gold bells for the feet, and a shield which had in the center a round plate of gold, which shield was bordered with rich feathers. From the lower part of the shield came out a sash of rich feathers in the shape of the one above described: it had a staff wrought in turquois mosaic, and its crook was set with rich stones or conspicuous pearls. They also had on top of it all some sandals (cotaras), such as the lords were accustomed to wear. All these things were brought by the messengers and presented, as they say, to D. Hernando Cortés. Many other things they presented to him which are not written about, such as a miter of gold made like a periwinkle with edging of rich feathers which hung over the shoulders, and another plain miter of gold and other jewels of gold which are not written about. All these things were placed in hampers (petacas), and upon taking leave from Montezuma he said to them, "Go and worship in my name the god who comes, and say to him we have been sent here by your servant Montezuma: these things which we bring have been sent by him, for you have come to your dwelling, which is Mexico." These messengers set out on the road at once, and arrived at the seaside, and there took canoes [cañas, undoubtedly canoas was written], and arrived at a place called Xicalanco: from there they took other canoes with all their clothes, and reached the ships, and then those of the ships asked them, "Who are you, and whence have you come?" And those of the canoes answered, "We come from Mexico." And 
those of the ships said to them, "Perchance you are not from Mexico, but falsely say you are from Mexico and deceive us." And upon this they took and gave (bartered?), until they were satisfied on both sides, and they tied the canoe to the ship, and a ladder was let down, by which they climbed up to the ship and came to where $D$. Hernando Cortés was.

CHAPTER V. Of what happened when the messengers of Montezuma entered the ship of D. Hernando Cortés.

They commenced to climb up to the ship on the ladders, and brought the presents that Montezuma had commanded them to carry. When they were in front of the captain D. Hernando Cortés, all kissed the ground [deck] in his presence, and spoke in this wise: "May the god whom we come to adore in the name of his servant Montezuma, who for him rules and governs the city of Mexico, know, and who says that the god has come after much hardship." And at once they took out the ornaments they had brought, and placed them in front of the captain D. Hernando Cortés, adorning him with them, placing first the crown and mask which has been described above, and all the other things: they put around his neck the collars of (precious) stones with the jewels of gold which they had brought, and put on his left arm the shield above described, and all the other things were placed in front of him in the order they were accustomed to put their presents. The captain said, "Is there something more?". And they said to him, "We have not brought anything else than these things that are here." The captain at once ordered them to be tied, and ordered shots of artillery fired, and the messengers who were tied hand and foot, when they heard the thunder of the bombardment, fell on the floor like dead, and the Spaniards lifted them from the floor, and gave them wine to drink, with which they strengthened them and revived them. After this captain D. Hernando Cortés said to them, through the interpreter: "Listen to what I say to you. I have been told that the Mexicans are valiant men, that they are great conquerors and great warriors, and are very skilful at arms: they tell me that one Mexican alone is enough to conquer from ten to twenty of his enemies. I wish to prove whether this is true, and whether you are so strong as I have been told." Then he ordered swords and shields to be given them that they might fight with as many Spaniards, so that he might see 
who might win, and the Mexicans then said to captain Cortés, "May it please your grace to listen to our excuse, for we are not able to do what you command, and it is because our Lord Montezuma has sent us to do nothing else than to salute you and give you this present, we cannot do anything else, nor are we able to do what you order us, for if we did we should offend our Lord Montezuma, and he would order us killed." And the captain responded: "You will have to do by all means what I say. I have to see what kind of men you are, for over yonder in our country we have been told that you are very courageous men: arm yourselves with these arms and be ready that we encounter one another tomorrow on the (battle) field.

CHAPTER VI. Of how the messengers of Montezuma returned to Mexico with the report of what they had seen.

After what has been related was done, they took leave of the captain, and entered their canoes, and commenced to go toward the land, paddling with great speed, and saying to one another, "There are valiant men; let us exert ourselves to paddle before anything happens." They arrived very quickly at the town of Xicalanco, and there they ate and rested a little, and then they got into their canoes again, and paddling with great speed they arrived at the town called Tecpantlayacac, and from there began to journey by land, running with great speed, and they reached the town called Cuetlaxtla: there they ate and rested a little, and those of the town begged them that they should rest at least a day, but they responded that they could not, because they had to go with great speed to make known to Montezuma what they had seen, very new things, and never before seen nor heard of, of which no one else could speak about: and so traveling with great speed by night and day, they arrived in Mexico by night."

In the accounts of the vast treasure secured by Cortés from Montezuma before his untimely death, there is to be found no specific mention or description of objects decorated with stone mosaic. Much of the treasure secured in the final sack of Tenochtitlan (Mexico) was lost. The "empire" of the Aztecs was completely subjugated in I $52 \mathrm{I}$. From that time, and up to 1525, Cortés sent to Europe at various intervals great quanti- 
ties of loot, gathered as tribute from the stores of the Indians, accompanied with inventories, a number of which have been published. From these inventories we select the following items which clearly relate to stone mosaic objects.

Report of the Feather-work and Jewels sent to Spain to be distributed to the following Churches and Monasteries and Special Persons. [Without date.]

For the Lord Bishop of Burgos

Item: something like a staff (crosier) of stone mosaic-work of many colors, for him (the Bishop).

Copy of the Register of the Gold, Jewels, and other Things which are to go to Spain in the Ship Santa María de la Rábida, its Master (being) Juan Baptista. (The year 1522.)

This report contains a register of much treasure sent in one of the several ships which left Mexico in June, I522, in charge of the treasurer Julian Alderete, and Alonso Dávila and Antonio de Quiñones, proctors. The register contains statements of the monetary value of certain treasure registered by various persons, among whom we find one Juan de Rivera, who carried treasure for himself, Cortés, and other persons named in the inventory; but none of the articles is described. In the margin of the report are notes stating that a considerable portion remained in the Azores. In another inventory, from which we shall quote later, are descriptions of certain pieces, jewels, and feather-work that remained in the Azores in charge of the above-named proctors. According to Peter Martyr the greater part of this treasure was destined for the King of Spain, but it never reached him, for the vessel, which with the others had put into the Azores to escape French pirates, was captured later by these corsairs and the rich spoils of the Aztecs went to augment the treasure of Francis I.

The ship Santa Maria de la Rábida seems to have arrived in Sevilla in November, I522, and Peter Martyr saw the treasure that it brought and interviewed Juan de Rivera at. 
length concerning the people and country of New Spain. The account which he wrote, based on a view of the wonderful objects and what Rivera had told him, comprises an entire book in the Fifth Decade of his De Orbe Novo, first printed in I530. It contains a mass of valuable and generally trustworthy information, gleaned not only at first hand from Rivera, but also from a young native Mexican whom Rivera had brought to Spain as a slave and servant. This account supplies certain information describing the treasure, which is missing in the inventory. The report is so interesting that we quote what Peter Martyr writes about some of the objects of stone mosaicwork which Rivera displayed. ${ }^{21}$

We have been particularly delighted with two mirrors of exceptional beauty: the first was bordered with a circle of gold, one palm in circumference, and set in green wood; the other was similar. Ribera states that there is stone found in these countries, which makes excellent mirrors when polished; and we admit that none of our mirrors more faithfully reflect the human face.

We also admire the artistically made masks. The superstructure is of wood, covered over with stones, so artistically and perfectly joined together that it is impossible to detect their lines of junction, with the fingernail. They seem to the naked eye to be one single stone, of the kind used in making their mirrors. The ears of the mask are of gold, and from one temple to another extend two green lines of emeralds; two other saffron colored lines start from the halfopened mouth, in which bone teeth are visible; in each jaw two natural teeth protrude between the lips. These masks are placed upon the faces of the gods, whenever the sovereign is ill, not to be removed until he either recovers or dies.

Peter Martyr gives us details regarding the King's share of the loot brought by the Santa María de la Rábida, writing as follows:

Without mentioning the royal fifth, that ship brings the treasure which is composed of a part of what Cortés amassed, at the cost of risks and dangers, and the share belonging to his principal lieutenant: they offer it all in homage to their King. Ribera has been instructed to present to the Emperor in his master's [Cortés'] name the 
gifts he sends, while the others will be presented in the name of their colleagues by the officers who, as I have said, remained behind at the Azores. . . . The treasure destined for the Emperor is on board the vessel which has not yet arrived: but it is said that it amounts to 32,000 ducats of smelted gold in the form of bars. Were all the rings, jewels, shields, helmets, and other ornaments now smelted, the total would amount to I50,000 ducats. The report has spread, I know not how, that French pirates are on the watch for these ships: may they come safely in.

As we have stated, the ships were captured and the treasure was irretrievably lost to the Spaniards. An inventory of the treasure, preserved in Spain, reads:

Statement of Pieces, Jewels, and Feather-work sent from New Spain for

His Majesty, and that Remained in the Azores in the Charge of Alonso Dávila and Antonio Quinoñes. [Without date.]

Statement of the pieces, jewels, and feather-work that are sent to Their Majesties in the following boxes:

A shield with blue stone mosaic-work with its rim of gold.

A shield of stone mosaic-work, with a rim of blue and red feathers.

A shield of stone mosaic-work, the casco (crown) of feathers and the clasps of gold, and on the rim some long green feathers.

A shield of stone mosaic-work and confas (shells) with some pendants on the rim, of large and small gold bells.

Report of the Objects of Gold that are Packed in a Box for His Majesty which are Sent in Care of Diego de Soto. [Without date.]

A face of gold with the features of stone mosaic-work.

A face of tiger-skin [sic] with two ear-ornaments of gold and stone mosaic-work.

Report of the Things Carried by Diego del Soto from the Governor in Addition to what he Carries Listed in a Notebook of Certain Sheets of Paper for His Majesty. [Without date.]

A large shield with some moons of stone mosaic-work and with much gold.

Two stone mosaic-work shields.

The final inventory from which we extract items relating to stone mosaic-work objects is dated 1525 . It is: 
Report of the Gold, Silver, Jewels, and Other Things that the Proctors of New Spain Carry to His Majesty. (Year of 1525.)

A large head of a duck of blue stone mosaic-work.

Two pieces of gold, such as the natives of these parts wear in their ears with some red and blue stones, weighing altogether ten pesos.

A bracelet with four greenstones set in gold like the hoof of a stag. Not weighed.

Another bracelet of gold with ten pieces like azicates, and two claws of greenstone set in gold.

An armlet of tiger-skin with four greenstones and four small bars of gold of little weight.

A shell like a venerica set in gold with a greenstone in the center.

A large shell set in gold with a face of greenstone, with some blue and yellow little stones around the neck.

A butterfly of gold with the wings of venera, and the body and head of greenstone.

Two veneras, one purple and the other yellow, each one respectively with greenstones in the center and other blue ones around it, set in gold.

Another white venera, set in gold, having some blue and red eyes, the one inserted in the other.

A monster of gold with some greenstone mosaic-work in the belly, weighing altogether eleven pesos.

A poniard (or jewel broncha) of white shell set in gold, weighing altogether thirty-seven pesos, five tomins.

A butterfly of shell, of fancy work, set in gold, weighing altogether eleven pesos, six tomins. ${ }^{22}$ 


\section{TRIBUTE OF MOSAIC PAID TO THE AZTEC RULERS}

MosaIC objects, and especially the raw material for their manufacture, formed a part of the annual tribute paid by some of the coast provinces of ancient Mexico to the Aztec kings of Tenochtitlan. We have the pictorial representation of some of the objects of such tribute in an important native book or codex, painted in colors on maguey fiber paper, known as the Tribute Roll of Montezuma. This original codex was at one time in the famous Boturini collection, and is now one of the treasured possessions of the Museo Nacional in the City of Mexico. It lacks, however, several leaves which were abstracted about a century ago, and which came into possession of Joel R. Poinsett, who had been American Minister to Mexico, and who presented them to the American Philosophical Society of Philadelphia in 1830, where they now are. On the pages have been written explanations of the pictures and figures in both Nahuatl and Spanish. "The Nahuatl words look as if made by a pencil, style, or short brush similar to that used in delineating the figures, and with a sepia-like preparation; while the Spanish ones have evidently been made with an ink containing iron, and an instrument which disturbed the gloss of the paper, as is shown by its penetration to fibres adjacent, giving the lines a sort of hazy margin occasionally." 23

Some time between the years I534 and I550, Don Antonio de Mendoza, the first Viceroy of Mexico, during this period, had the Indians prepare for the Emperor Charles V, a book on European paper, containing a pictorial account, in colors, of some things relating to the history and life of the natives of the Mexican plateau. It was painted in three sections, the first being a chronological record of the Aztec kings and their conquests, the third relating to the habits and customs of the natives and especially of the education of Mexican youth. 


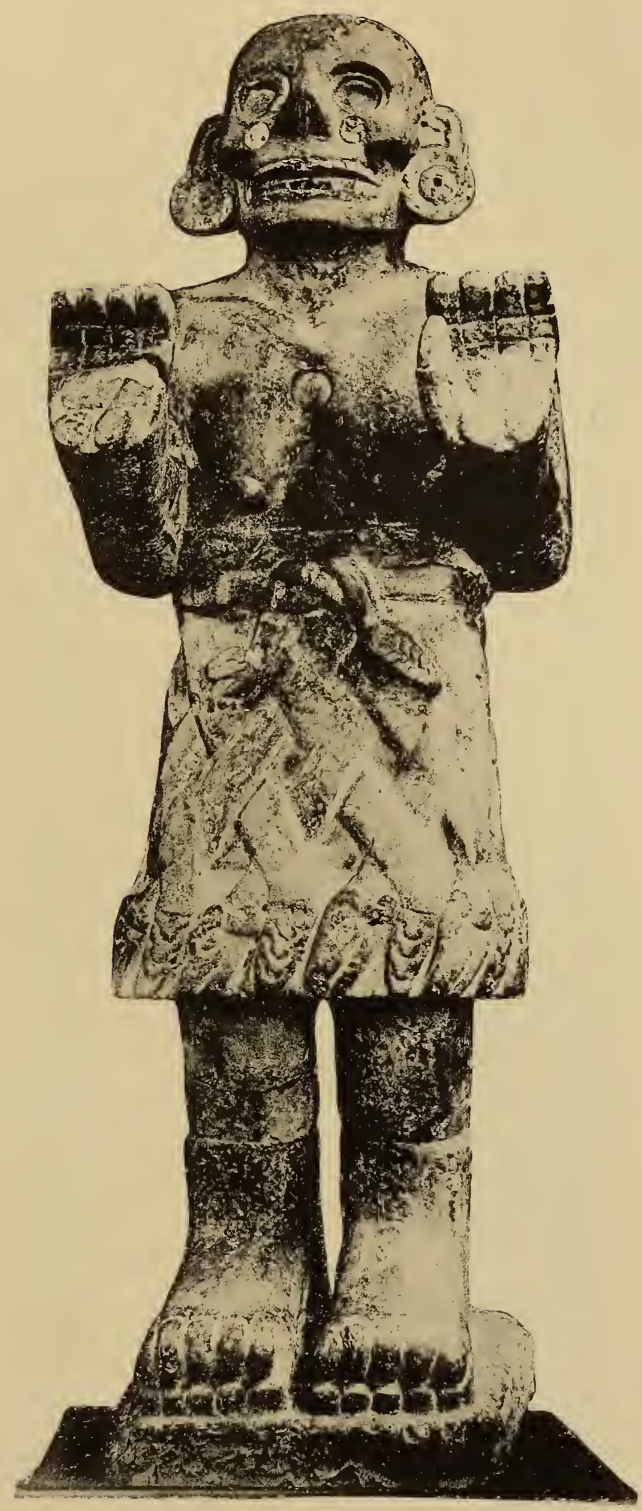

STONE IDOL; THE GODDESS COATLICUE, WITH MOSAIC DECORATION NATIONAL MUSEUM, MEXICO 

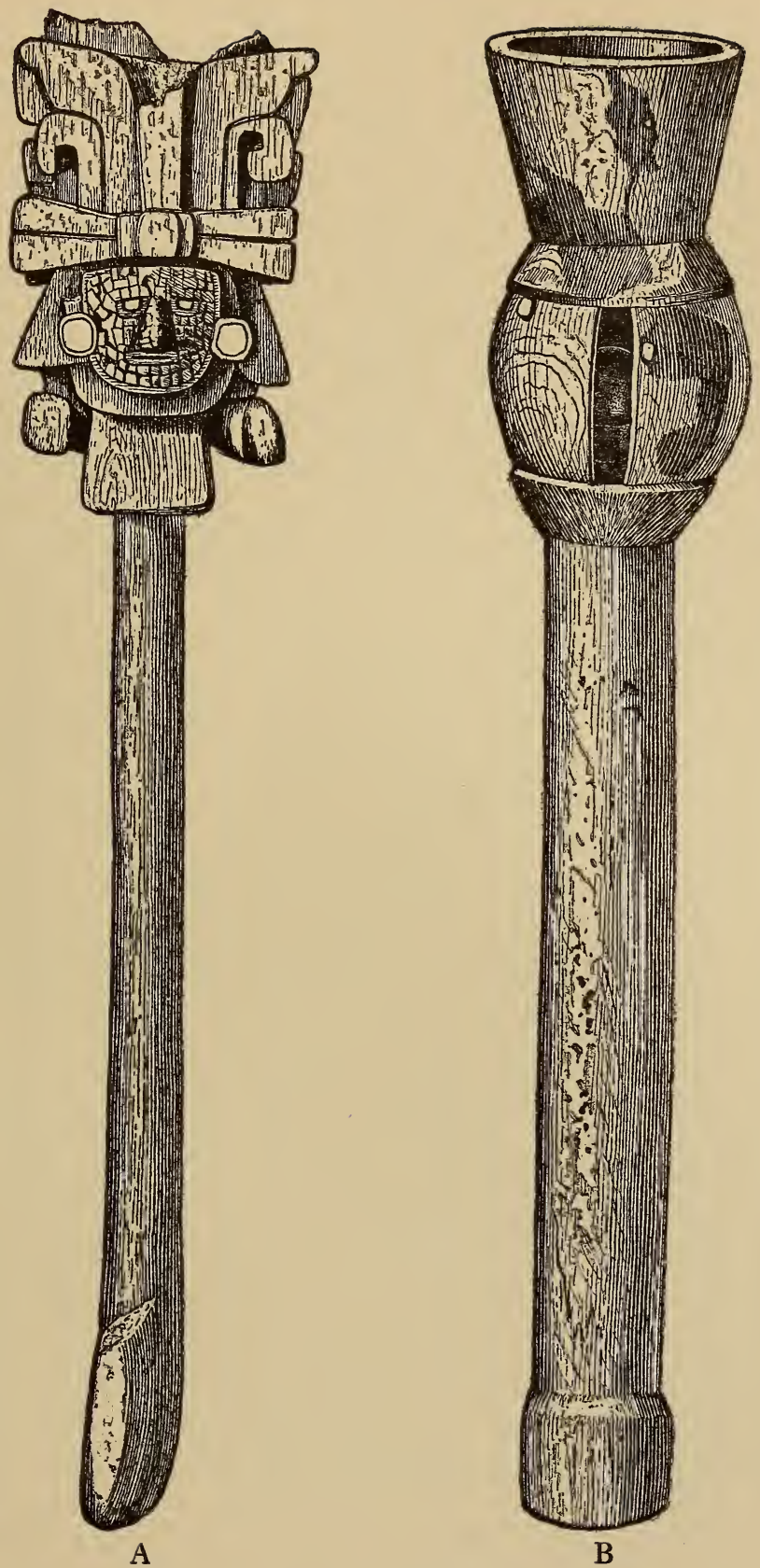

STAFF AND RATTLE OF WOOD WITH MOSAIC DECORATION

PEABODY MUSEUM, CAMBRIDGE 

The second part was a copy of the Tribute Roll above referred to. These pictures were given to other Indians for the interpretation of their import, which was written down in the Nahuatl language, and another person, well versed in both the Indian and Spanish languages, made a translation into Spanish, which was incorporated in the book. It was then despatched to Spain, probably about the year I549, but the vessel was captured by French pirates, and the book came into the hands of the French geographer, Andre Thevet, in 1553. After Thevet's death it was purchased, about the year I584, by Richard Hakluyt, at that time chaplain to the English Ambassador to France. Hakluyt bequeathed the volume to Samuel Purchas, who published it, without colors, with an English translation of the text, in Purchas His Pilgrimes, London, 1625. The English text was translated into French and accompanied with the plates was published by Melchisedec Thevenot in his Relations des Divers Voyages, in I663. The codex ultimately became the property of Selden, and with some other original Mexican codices later became a part of the Bodleian Library at Oxford, where it is now preserved. In I831, Lord Kingsborough issued it for the first time in colors, together with a new and more accurate English rendering of the Spanish text, in his monumental work on the Antiquities of Mexico.

The Tribute Roll was published by Archbishop Lorenzana in Mexico in 1770, in his edition of the Cartas de Cortés, the drawing, uncolored, being traced in a very inferior manner from the original in Mexico. Finally, Dr. Antonio Peñafiel included a beautiful colored facsimile of the Tribute Roll in his work, Monumentos del Arte Mexicano Antiguo, published in Berlin in I890, the missing leaves, in Philadelphia, being reproduced from a very poor drawing of the codex on European paper, probably executed for Boturini. These leaves were published in exact facsimile in 1892 , with an article entitled, The Tribute Roll of Montezuma, edited by Dr. D. G. Brinton and Henry Phillips, in vol. XviI of the Transactions of the American Philosophical Society. 
On plate XVIIr (we refer to the Peñafiel edition), in the second section of the plate, among other objects of tribute is a small bowl containing pieces of cut turquois (see fig.

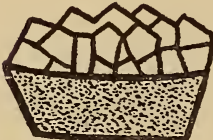

FIG. I I). In the explanation given by Purchas, this item is described as "a little panne full of Turkes stones," and in the Kingsborough text it has been translated "a little vessel of small turquois stones." On the plate published by Lorenzana is the caption, "Matlauac Rosilla con q. se tiñe azul." The word matlauac is probably a corruption of the Nahuatl word matlaltic, meaning 'blue,' but the rest of the sentence in Spanish is confused, for rosilla means 'reddish,' and con q. se tiñe azul, 'with which they dyed blue,' seems to indicate that the phrase is incomplete. Accompanying the objects depicted as tributes are the hieroglyphs of the towns which paid them. These glyphs have been interpreted in the same manner in all of the reproductions of the codex, but we use the spelling adopted by Peñafiel, in preference to that given by Purchas or by Kingsborough. They are: (I) Quiyauhtecpan, "temple of rain or of its deities" Tlaloc or Chalchiuhtlicue; (2) Olinalan, "place of earthquakes;" (3) Cuauhtecomatlan, "place of tecomates;" (4) Cualac, "place of good drinkable water;" (5) Ichcatlan, "cotton-plantation;" (6) Xala, "sandy ground." These places are given in the explanation as being "cities of warm provinces."

In the third section of the same plate (XVIII) are the objects shown in figs. 2 and 3. Peñafiel writes of fig. 2 as "ten little figures worked in turquois." Only one object painted blue is depicted, the number ten being indicated by the ten dots. That masks form this tribute is clearly evident; in Purchas the description is "tenne halfe faces of rich blew Turkey stones," and in Kingsborough, "likewise ro middling sized masks of rich blue stones like turquois."

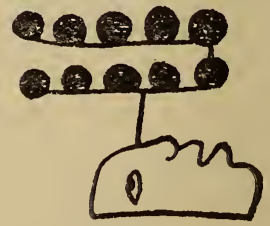

FIG. 2 


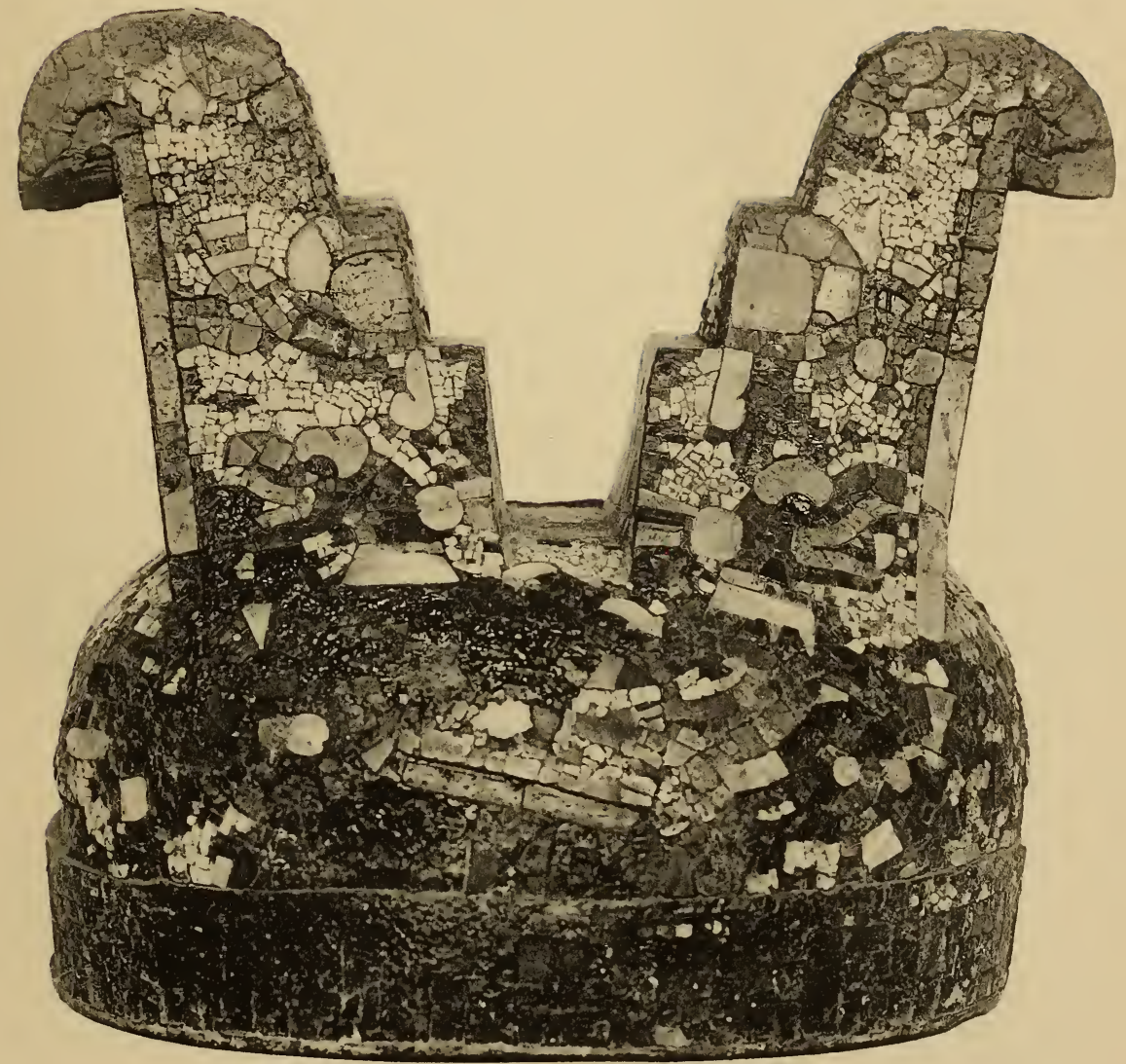

HELMET OF WOOD WITH MOSAIC DECORATION

BRITISH MUSEUM, LONDON 

The second item in this section (fig. 3) is described by Peñafiel as "a small bag of the same stones." Kingsborough's statement is, "a large bag of the said blue stones," while in Purchas the translation reads, "a great trusse full of the said Turkey stones." On the bag which is painted blue, with two red vertical bands, is the Aztecan hieroglyph for stone, tetl.

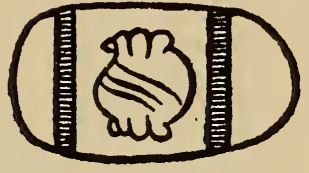

FIG. 3 The towns whence this tribute was exacted are: (I) Yoaltepec, "place consecrated to the deity of the night;" (2) Ehaucalco, "in the place of tanning;" (3) Tzilacapan, "river of chilacayotes;" (4) Patlanalan, "place where parrots abound;" (5) Ixicayan, "where the water comes down;" (6) Ichcaatoyac, "river of cotton." These cities are of the warm provinces.

The only finished objects of mosaic-work in the Tribute Roll are on plate xxxiI. This is one of the leaves of the original
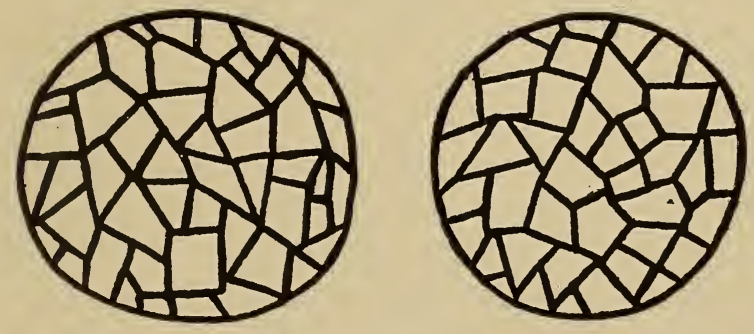

FIG. 4 codex in Philadelphia, and we have traced fig. 4 from this original. They are described by Purchas as "two pieces like platters decked or garnished with rich Turkey stones." Kingsborough mentions them as "two pieces like salvers ornamented or set with rich turquoise stones." Lorenzana has correctly printed the legend which we find reproduced in the Philadelphia publication of this leaf; it is "Ontetl xiuhtetl," followed by the Spanish, "turquesas o piedras finas." Ontetl is Nahuatl for "two," and xiuhtetl, or xiuitl tetl, "turquois stone." The mosaic character of these two pieces is graphically represented by the ancient artist. The towns paying the tribute illustrated on this sheet are as follows: (I) Tochpan, or Tuchpan, "over the rabbit;" 
(2) Tlaltizapan, "place situated over chalk;" (3) Cihuateopan, "in the temple of Cihuacoatl;" (4) Papantla, "place of the priests;" (5) Ocelotepec, "place of the ocelot;" (6) Mihuapan, "river of the ears of corn;" (7) Mictlan, "place of rest."

In the Crónica of Tezozomoc is an account of the campaign of the Aztecan king Ahuitzotl into southern Mexico in 1497. The towns of Xuchtlan, Amaxtlan, Izhuatlan, Miahuatla, Tecuantepec, and Xolotlan, in the region of the Isthmus of Tehuantepec, had revolted against him. After the complete rout of the rebellious Indians, it was related by Tezozomoc that "the kind of arms carried by the coast people was very rich, so much so that the undisciplined soldiers began to strip the bodies of the dead of the very rich feather-work pieces called quetzalmanalli, and from their military ornaments remove a round emerald like a mirror which sparkled in its perfection, called xiuhtezcatl. Others of the dead carried on the back of their arms that which was called yacazcuil, outside of fine gold, and in the nose they wore stones; others (wore) gold, and the shield which they carried had a very rich greenstone in the center, and around it a decoration of very fine stones set in (mosaic-work), said shield being called xiuhchimal." Those who remained after the slaughter came to Ahuitzotl, saying: "Our Lords, let us speak. We will give our tribute of all that is produced and yielded on these coasts, which will be chalchihuitl of all kinds and colors, and other small stones called teoxihuitl (turquois) for setting in very rich objects [mosaic], and feathers of the richest sort brought forth in the whole world, very handsome birds, the feathers of which are called xiuhtototl, tlaquechol, tzinitzcan, and zacuan; tanned skins of the tiger (ocelot), lions (puma), and great wolves, and other stones veined with many divers colors." ${ }^{24}$

In the same Crónica we read that Montezuma, who succeeded Ahuitzotl after his death in $\mathrm{I}_{502}$, received a royal tribute from his vassals in Xaltepec, a coast town of Tehuantepec, among which were "broad collars [sic] for the ankles, strewn with gold grains and very rich stone mosaic-work." ${ }^{25}$ 


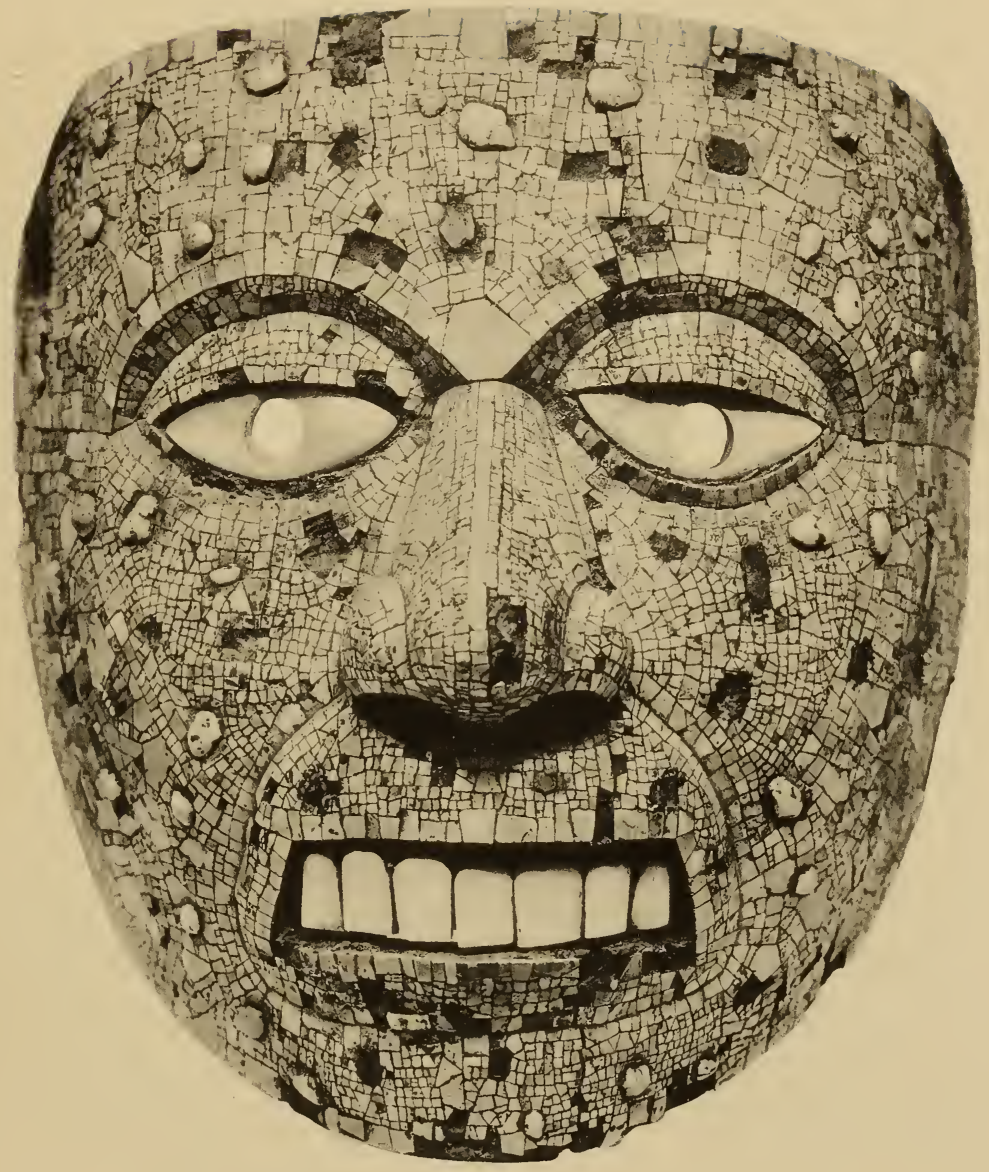

MASK OF WOOD WITH MOSAIC DECORATION

BRITISH MUSEUM, LONDON 



\section{SOURCE OF TURQUOIS}

THE source of the considerable quantity of turquois used in Mexico in pre-Spanish times for personal ornaments and mosaic incrustation is still an unsolved problem. Thus far no prehistoric workings have been found in Mexico. Only recently turquois has been discovered at the silver mines at Bonanza, Zacatecas, but Dr. Kunz, who has called our attention to this, writes that he has no information regarding prehistoric workings there. ${ }^{26}$ In the extensive bibliography on the geology of Mexico by Aguilar y Santillan ${ }^{27}$ we find only a single entry for turquois, that being the study of Mexican mosaics in Rome by Pigorini. ${ }^{28}$ Pogue ${ }^{29}$ writes that there are no important turquois deposits that do not show signs of prehistoric exploitation, and he is also of the opinion that it is very difficult to trace the source of the turquois used by the Indians of ancient Mexico and Central America. Pogue's conclusion is that "as no occurrence at all adequate as an important source has been discovered south of the present Mexican boundary, it therefore seems probable that the Aztecs and allied peoples, through trade with tribes to the north, obtained supplies of turquois from the Cerrillos hills [New Mexico] and perhaps other localities of the Southwest."

Sahagun is the only early chronicler who affords information concerning this point. He writes explicitly that "the Toltecs had discovered the mine of precious stones in Mexico, called xiuitl, which are turquoises, which mine, according to the ancients, was in a hill called Xiuhtzone, close to the town of Tepotzotlan [State of Hidalgo]." We will quote other statements by Sahagun concerning turquois:

The turquois occurs in mines. There are some mines whence more or less fine stones are obtained. Some are bright, clear, and transparent; while others are not ... Teoxiuitl is called turquois of the gods. No one has a right to possess or use it, but always it 
must be offered or devoted to a deity. It is a fine stone without any blemish and quite brilliant. It is rare and comes from a distance. There are some that are round and resemble a hazelnut cut in two. These are called xiuhtomolli.... There is another stone, used medicinally, called xiuhtomoltetl, which is green and white, and very beautiful. Its moistened scrapings are good for feebleness and nausea. It is brought from Guatemala and Soconusco [State of Chiapas]. They make beads strung in necklaces for hanging around the neck. ... There are other stones, called xixitl; these are low-grade turquoises, flawed and spotted, and are not hard. Some of them are square, and others are of various shapes, and they work with them the mosaic, making crosses, images, and other pieces. ${ }^{30}$

If we are to credit Sahagun, turquois was worked not only in the immediate region of the central Mexican plateau, but they received supplies from distant points, and specifically from Chiapas and Guatemala. The raw material mentioned in the Tribute Roll of Montezuma as coming from coast towns and from the south, must also be taken into consideration. Hence, notwithstanding the present lack of information respecting the localities where turquois is to be found in situ in central and southern Mexico, we cannot reject the opinion that ultimately ancient workings will be found at more than one site in Mexico. We do not believe it necessary to assume that the source of supply of both the Toltecs and the Aztecs, as well as of other tribes, such as the Tarasco, and the Mixtec and Zapotec, which also made use of this material, was the far-distant region of New Mexico. It was formerly asserted by some students that the jadeite of Middle America must have come by trade from China, ${ }^{31}$ because no deposits have as yet been found in the former region; but it is now known by chemical analysis that the Middle American jadeite is distinct from that of Asia. In fact, the writer has long held that not alone in one, but in at least five, different localities, jadeite will in time be discovered..$^{32}$ 




MASK OF WOOD WITH MOSAIC DECORATION BRITISH MUSEUM, LONDON 



\section{THE AZTEC LAPIDARIES AND THEIR WORK}

THE development of the art of the lapidaries and mosaicworkers, like that of the goldsmiths, is attributed by Sahagun to the Toltecs, under the beneficent influence of Quetzalcoatl, the culture hero god. In treating of the pre-Aztec people called Tultecas, or people of Tollan or Tula, by Sahagun, he states that they were very skilful in all that pertained to the fine arts. He writes:

The Tultecas were careful and thorough artificers, like those of Flanders at the present time, because they were skilful and neat in whatsoever they put their hands to; everything (they did) was very good, elaborate, and graceful, as for example, the houses that they erected, which were very beautiful, and richly ornamented inside with certain kinds of precious stones of a green color as a coating (to the walls), and the others which were not so adorned were very smooth, and worth seeing, and the stone of which they were fashioned appeared like a thing of mosaic. . . . They also knew and worked pearls, amber, and amethyst, and all manner of precious stones, which they made into jewelry. ${ }^{33}$

We find another statement to the effect that-

The lapidary is very well taught, and painstaking in his craft, a judge of good stones, which, for working, they take off the rough part and bring together or cement with others very delicately with bitumen or wax, in order to make mosaic-work. ${ }^{34}$

In the pictorial section of the Florentine manuscript of Sahagun, ${ }^{35}$ in the Codex Mendoza, ${ }^{36}$ and in the Mappe Tlotzin, ${ }^{37}$ are pictures delineating artisans engaged in various crafts, such as weavers, painters, carpenters (wood-carvers), stone carvers, lapidaries, goldsmiths, and feather-mosaic workers, yet we find no actual representation of turquois-mosaic workers. In the third section of the Codex Mendoza appears a picture of a father teaching his son the secrets of the lapidary's art. The interpreter of the codex writes: 
The trades of a carpenter, jeweler (lapidary), painter, goldsmith, and embroiderer of feathers, accordingly as they are represented and declared, signify that the masters of such arts taught these trades to their sons from their earliest boyhood, in order that, when grown up to be men, they might attend to their trades and spend their time virtuously, counseling them that idleness is the root and mother of vices, as well as of evil-speaking and tale-bearing, whence followed drunkenness and robberies, and other dangerous vices, and setting before their imaginations many other grounds of alarm, that hence they might submit to be diligent in everything.

The elaborate series of pictures of the various crafts in the Florentine manuscript of Sahagun (laminas liv to lxiv) includes those that show in detail the work of the goldsmiths and the feather-workers; but the illustrations devoted to the lapidaries we are unable to correlate, in the absence of the text, with the Nahuatl text of the Sahagun manuscript in the Real Academia de la Historia in Madrid, which we will give later from the study by Dr. Seler containing a translation of the native text into French. This description of the work of the lapidaries informs us only concerning the working and polishing of the stones. Unlike the other accounts by Sahagun regarding the goldsmiths and the feather-workers, which enlighten us with respect to the details of these two fine arts, he does not here enter into any description concerning the delicate work of the artists who fashioned the beautiful pieces of stone mosaic. Although such work was turned out by the Aztecan workmen, as we have already demonstrated, it seems highly probable that in times immediately preceding the Spanish conquest, the Aztecan kings Ahuitzotl and Montezuma obtained a considerable number of such objects through tribute and by barter with the tribes living in what are now the states of Vera Cruz, Oaxaca, and western Chiapas. As our knowledge of Mexican archeology, now all too meager, is extended, it is very probable that we will find vestiges of this art in the Pacific state of Guerrero, where great numbers of jadeite and other greenstone objects have been discovered, with a respect- 


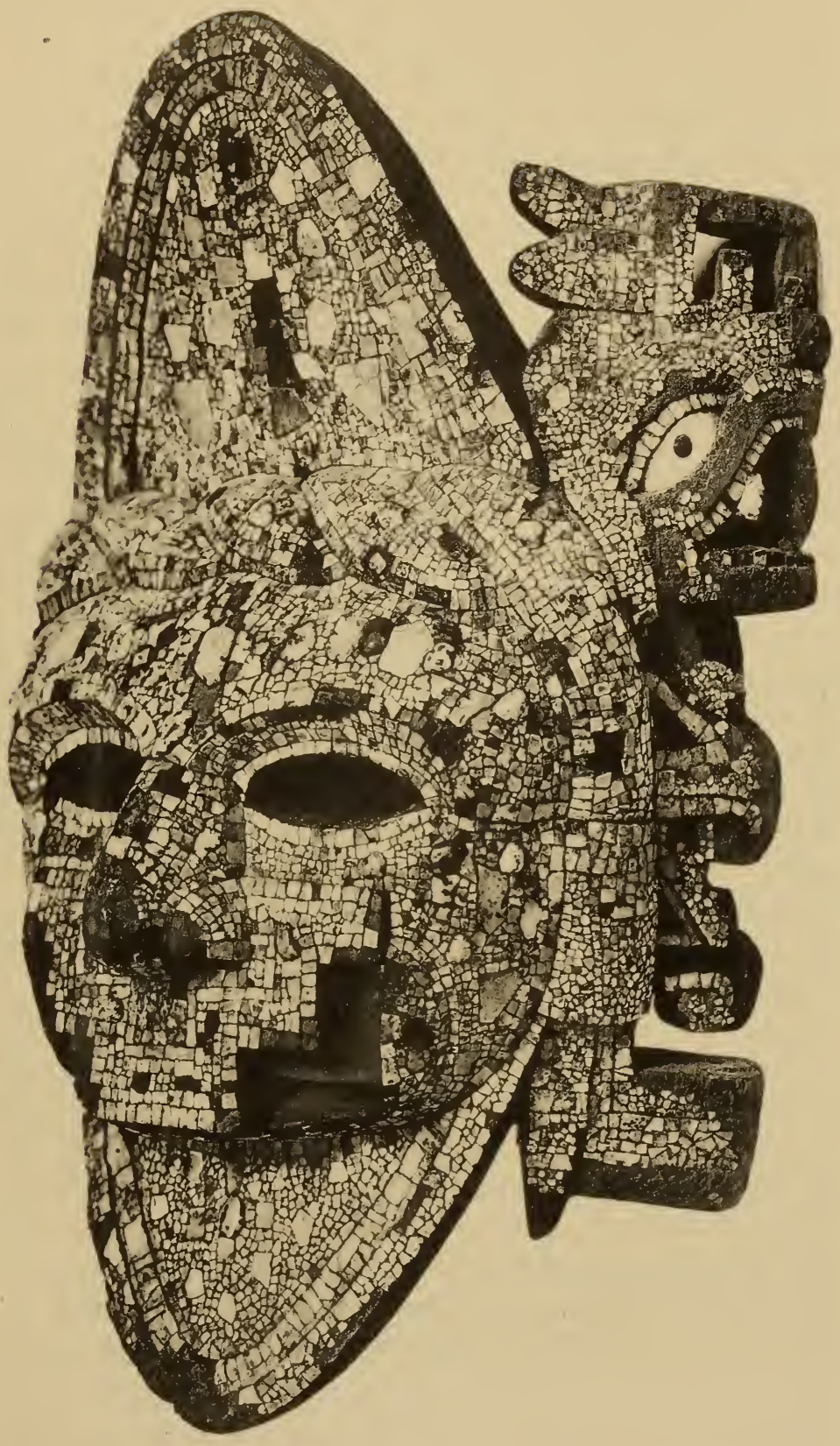

MASK OF WOOD WITH MOSAIC DECORATION PREHISTORIC AND ETHNOGRAPHIC MUSEUM, ROME 

able number of specimens indicating the high artistic skill of the indigenes of that section. We may also hope to find relics of this art in the area of Matlaltzincan culture to the north of the valley of Mexico, and also in the field of Tarascan culture in the states of Michoacan and Jalisco, for, as will be related, mosaic specimens have been recovered from ancient ruins as far north as the State of Zacatecas.

Sahagun's account (chap. II) of the work of the lapidaries we herewith append, with the Nahuatl text and a translation of the French rendering by Seler. ${ }^{38}$

I. In tlateque tulteca ynic quitequi yn yztac tehuilotl yoan tlapaltehuilotl yoan chalchiuitl yoan quetzalitztli ynica teoxalli yoan tlaquauac tepuztli.

I. The lapidary artisans cut rock-crystal, amethyst, emerald, both common and precious, by means of emery and with an instrument of tempered copper:

2. Auh ynic quichiqui tecpatl tlatetzotzontli.

2. And they scraped it by means of cutting flint.

3. Auh ynic quicoyonia ynic quimamali teputztlacopintli.

3. And they dug it out (hollowed) and drilled it by means of a little tube of copper.

4. Niman yhuian quixteca quipetlaua quitemetzhuia, auh yn $y c$ quicencaua.

4. And then they faceted it very carefully; they burnished (polished) it and gave it the final luster.

5. Ytech quahuitl yn quipetlaua ynic pepetlaca, ynic motonameyotia ynic tlanextia.

5. They polished it set in wood, so that it comes to be very brilliant, shining, glossy.

6. Anoşo quetzalotlatl ynitech quilau ynic quicencaua ynic quiyecchiua yn intultecayo tlatecque.

6. Or they polish it mounted in bamboo, and the lapidaries finish it thus, and conclude their work.

7. Auh çannoiuhqui yn tlapaltehuilotl ynic mochiua ynic mocencaua.

7. And in the same manner they work and smooth amethyst.

8. Achtopa quimoleua quihuipeua teputztica yn tlatecque yn tulteca ynic yyoca quitlatlalia yn qualli motquitica tlapaltic yn itaqui. 
8. In the first place the lapidary artisans break into pieces the amethyst and crush it with an instrument of copper, for they work only the beautiful pieces which are entirely reddish.

9. Can niman yuhqui tlatlalia yn campa monequiz quimoleua tepuztica.

9. They do not set up the precious stones named in this manner, except in the parts where it is necessary, when they break them with the copper instrument.

10. Auh niman quichiqui quixteca yoan quitemetzhuia yoan quipetlaua ytech quahuitl yn tlapetlaualoni ynic quiyectilia ynic quicencaua.

Io. Then they scrape it, and they facet it, and they smooth it, and they polish it, mounted in wood, set on the instrument called polisher or burnisher, and they manufacture and finish it.

I1. Auh yn yehoatl yn moteneua eztecpatl ca cenca tlaquauac chicauac camo ma vel motequi ynica teoxalli.

I I. The stone called blood silex (heliotrope) is very hard and very strong, and they do not cut it well with emery.

12. Caçan motlatlapana motehuia.

12. They break it and they cut it up in any kind of way.

13. Yoan motepehuilia yn itepetlayo yn amo qualli, yn amo uel no mopetlaua.

13. And they throw away the vein-stone, the useless stone, that which does not lend itself readily to polishing.

14. Can yehoatl mocui motemolia yn qualli, yn vel mopetlaua yn eztic, yn uel cuicuiltic.

14. They do not take or seek except the beautiful pieces that lend themselves to good polishing, the red-banded, that permit themselves to be well cut.

15. Michiqui atica yoan ytech tetl cenca tlaquauac vnpa uallauh yn matlatzinco.

15. They rub them with water and mounted in a very hard stone that comes from the country of Matlatzinca [district of Toluca].

16. Ypampa ca uel monoma namiqui, yniuh chicauac tecpatl noyuh chicauac yn tetl, ynic monepanmictia.

16. And because these two stones are companions, the one to the other, as the silex is very hard, so the stone is hard, they kill one another (the one kills the other).

17. Catepan mixteca yca teoxalli yoan motemetzhuia yca ezmellil.

17. Then they facet and polish them by means of emery. 


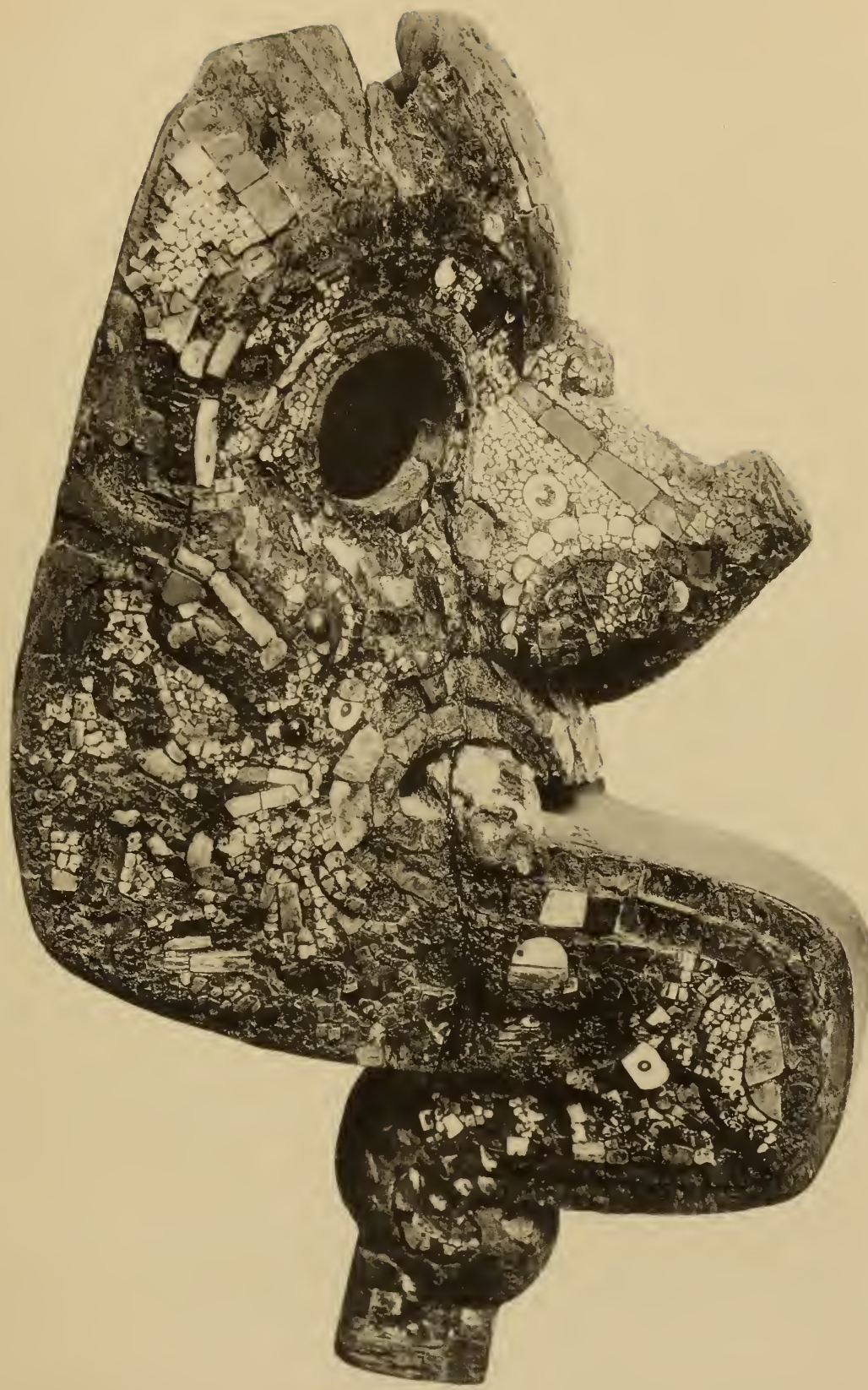

MASK OF WOOD WITH MOSAIC DECORATION

PREHISTORIC AND ETHNOGRAPHIC MUSEUM, ROME 

18. Auh çatepan yc mocencaua yc mopetlaua, yn quetzalotlatl.

18. And they finish and polish them with bamboo.

19. Ynic quicuecueyotza quitonameyomaca.

19. In this way they make them scintillate and give to them a luster like the rays of the sun.

20. Auh yn yehoatl motocayotia vitzitziltecpatl niman yuh yolli tlacati.

20. And that which they call hummingbird silex (stone of a thousand colors) is (in color like) an animal of that nature.

21. Miyec tlamantli ynic mocuicuiloua, iztac yoan xoxoctic yoan yuhquin tletl, anoço yuhqui citlali yoan yuhquin ayauhcoşamalotl.

2I. It is tinted (painted) in a thousand colors, white, blue, clear brilliant red, black with white spots, and the color of the rainbow.

22. Can tepiton xalli ynic michiqui ynic mopetlaua.

22. They scrape it and simply polish it with fine sand.

23. Auh yn yehoatl motocayotia xiuhtomolli camo tlaquauac camo ezmellil ytech monequi ynic michiqui ynic mixteca yoan ynic motemetzhuia yoan ynic mopetlaua ynic moquetzalotlahuiaya ynic motonameyotia motlanexyotia.

23. The stone that they call round turquois is not very hard, so they have no need of emery to scrape, facet, smooth, or polish, for they apply to it the bamboo, then it receives its radiant luster and brilliancy.

24. Auh yn yehoatl teoxihuitl ca amo cenca tlaquauac.

24. The fine turquois is not very hard either.

25. Canno tepiton xalli ynic mopetlaua ynic moyectilia auh yn uel no yc motlanextilmaca motonameyomaca occentlamantli ytoca xiukpetlaualoni.

25. They polish it likewise with fine sand and they give to it a very brilliant luster and radiance by the method of another polisher, called the polisher of turquois.

Regarding the patron deities of the lapidaries, Sahagun has given us a detailed account which is so interesting that we translate in extenso.

The lapidaries who worked precious stones in the time of their pagandom adored four gods, or better said devils: the first was called Chicunavitzcuintli, the second Naoalpilli, the third Macuilcalli, and the fourth Cintcutl: to all these last three gods they made a 
festival when there reigned the sign or character called Chicunavitzcuintli, which is a woman, and for this (reason) they painted it so: to this (one) they attributed the cosmetics of the women, and in order to signify this they painted it with a crosier in the right hand, and in the left they put a shield, in the which (shield) there was represented a foot. They also put ear-ornaments of gold on it, and from the cartilage of the nose hung a butterfly of the same metal, and they dressed it (the idol) with a uipil and woman's shirt that was woven white and red, and also the skirts: they put on some sandals, also colored, having some paintings that appeared like almonds. To all these four (gods) they gave their images or their titles, so that they might die in their service on the day of their festival. That one called Naoalpilli they decked out, and they cut the strands of hair in unequal lengths, very badly cut, disheveled or standing on ends, and divided in two parts. They put on the forehead a delicate plate of gold (thin) like paper, some earrings of gold in the ears, and in the hand a crosier decorated with rich feathers, and in the other (hand) a shield made like a net, and in four parts it had rich feathers badly placed. They also dressed it with a jacket woven white and red, with edging in the lower end: they also put on it some colored sandals. And the other god, called Mactillcalli, they also composed like a man, the hair cut in the middle of the head like a ridge, that is called quachichiquille, and this ridge was not of hair but made of the richest feathers. They placed in the temples some plates of delicate gold, and a jewel hung from the neck also, made of a round and wide marine shell. In the hand a crosier made of rich feathers was placed, and in the other hand was a shield with some circles of red, some inside the others; they had the body painted vermilion color, and they also put on it some sandals of the same color. The other god, called Cinteutl, was fashioned in the likeness of a man, with a mask wrought like mosaic-work, with some rays of the same (mosaic-work), coming out of the same mask. They put on it a jacket of cloth dyed light-blue; a jewel of gold hung from the neck. They place it (the idol) on a high platform from which it looked out, which platform, called cincalli, was composed of cornstalks after the manner of a xacal. They adorned it with some white sandals, the fastenings of which were made of loose cotton; they say that to these gods they attribute the artifice of working precious stones, of the making of barbotes (the tops of helmets), and ear-ornaments of 


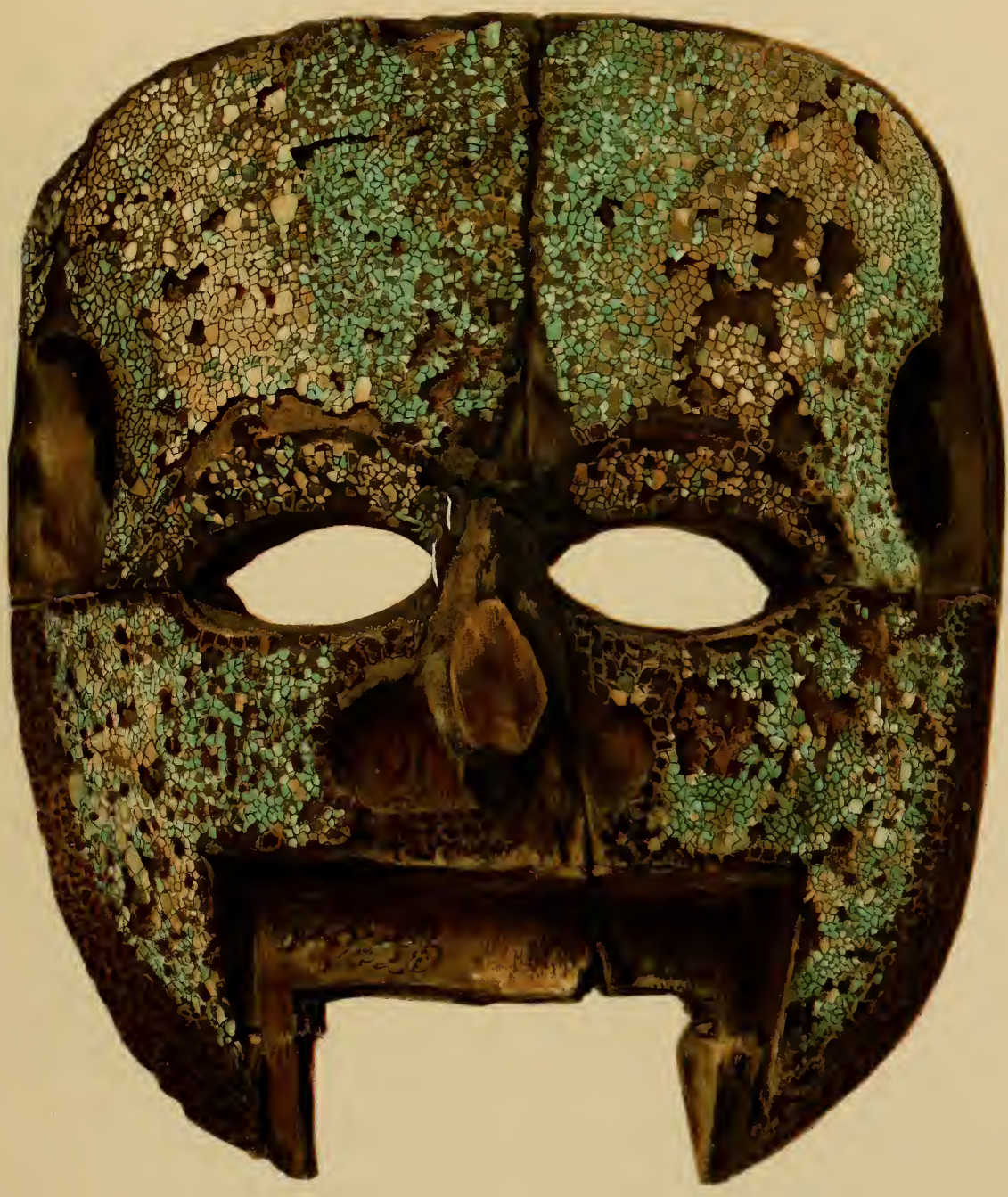

MASK OF WOOD WITH MOSAIC DECORATION

MUSEUM OF THE AMERICAN INDIAN HEYE FOUNDATION, NEW YORK 

black stone, of crystal, and of amber, and of other white (stones). They also attribute to these gods the working of beads, anklets, strings of pearls which they carried on their wrists, and all kinds of work in stones and chalchihuites, and the hollowing-out and polishing of all the stones; they said that these gods had invented it, and for this reason they were honored as gods, and to them the elder artisans of this craft and all the other lapidaries made a festival. By night they intoned their hymns and set the captives who were to die, on watch in their honor, and they did not work during the festival. This (festival) was celebrated in Xochimilco, because they said that the forefathers and ancestors of the lapidaries had come from that town, and there was the place of origin of these artisans. ${ }^{39}$

The ruler of the eighteenth week of the astrological calendar, or tonalamatl, was a goddess named Chantico or Quaxolotl, also nicknamed Chiconaui-itzcuintli, ${ }^{40}$ from the ninth day of the thirteen-day period or week. Seler writes:

She was the goddess of Xochimilco, and consequently also the chief deity of the guild of the tlatecque, of the stone cutters, the stone polishers, the jewelers, who were also supposed to come from Xochimilco. (Duran calls her wrongly Ciuacoatl and identifies her with the goddess of Colhuacan, which place stood opposite the city of Xochimilco). . . . Besides Chiconaui-itzcuintli the stone-cutters had still a few other titles for the goddess. Such were Papaloxaual and Tlappepalo, i.e., "she of the red butterfly painting," and "she with the red butterfly," and these have reference to fire. . . . The stone-cutters also gave their goddess a butterfly as her nasal ornament, which, red and white, are the colors of her robe. ${ }^{41}$

In some of the different versions or paintings of the tonalamatl contained in old Mexican codices, opposite the delineation of the goddess Chantico there is placed a fasting man in an enclosure. In both Codex Borbonicus ${ }^{42}$ and Codex Telleriano Remensis, ${ }^{43}$ this figure is found. Seler describes it as-

an enclosure inlaid with gold discs or rings. The interpreter designates it as "house of gold." Beyond doubt this name has reference to one of the four little fasting houses (necaualcalli) which the hero of Tollan, Quetzalcoatl, built for himself, and naturally corresponded 
to the four quarters of the heavens, the first of which was said to be made of gold or embellished with gold (coztic teocuitlacalli), the second decorated with red musselshells (tapachcalli), the third with turquoises (xiuihcalli), the fourth with white musselshells (teccizcalli).$^{44}$

Seler draws this inference from the legend given by Sahagun, which we have translated in full below.

As often is the case, there is some confusion in the description of Chantico in the early writings. This deity is also asserted to be a male. In the explanation of the Codex Telleriano Remensis the attributes of Chantico or Cuaxolotle are recited. It is said that-

Chantico presided over these thirteen signs (a division of the tonalamatl, or divinatory calendar), and was the lord of chile or of the yellow woman. He was the first who offered sacrifice after having eaten fried fish; the smoke of which (sacrifice) ascended to heaven; at which Tonacotli (Tonacatecutli, the father of all the gods) became incensed, and pronounced a curse against him that he should be changed into a dog, which accordingly happened, and he named him Chantico on this account, which is another name for Miquitlatecotle. From this transgression the destruction of the world ensued. He was called Nine Dogs, from the sign on which he was born. Chantico or Cuaxolotle is the symbol which the country people of Xolotle wear on their heads. ${ }^{45}$ (The symbol of the city of Xolotlan in the Codex Mendoza is the head of a Dog.)

In the Sahagun manuscript of the Real Palacio in Madrid ${ }^{46}$ the deity is painted with the shirt and skirt of a woman, and also in the Codex Borbonicus ${ }^{47}$ and the Tonalamatl Aubin. ${ }^{48}$ In his explanation of the last codex Seler has treated exhaustively of the various representations and attributes of this goddess. ${ }^{49}$

Among the laws of the Mexicans was the following:

They hung and very severely punished those sons who squandered the property left them by their fathers, or destroyed the arms, jewels, or remarkable things that their fathers had left. ${ }^{50}$ 




MASK OF WOOD WITH MOSAIC DECORATION

MUSEUM OF THE AMERICAN INDIAN HEYE FOUNDATION, NEW YORK 

In another study ${ }^{51}$ we have called attention, as follows, to the daily traffic of gold and precious stones in the great market of Tenochtitlan.

Cortés describes the great market of Tenochtitlan, and the great quantity of things daily exposed for sale included jewels of gold, silver, and stones. The Anonymous Conqueror, in describing the great market, states that "on one side of the plaza are those who sell gold, and adjoining are those who sell precious stones of various classes set in gold, in the shapes of various birds and animals." ${ }_{52}$ This refers to mosaic jewels with stone and gold inlays. Cortés further informs us that Montezuma had in his house representations in gold, silver, stones, or feathers, of every object of his domain, beautifully executed; and there is also a statement (by Ixtlilxochitl) that in the collection of Nezahualcoyotl, king of Texcoco, were the representations in stone mosaic-work and gold of every bird, fish, or animal which could not be obtained alive. ${ }^{53}$

A most interesting description is given by Sahagun of one of the edifices erected by the Toltecs in Tula. If true, it clearly shows that in pre-Aztec times much more elaborately decorated buildings were erected than in the more recent period, for there are no accounts in the writings of the Spaniards of such lavishly ornamented buildings existing in the numerous cities conquered by them during the beginning of the sixteenth century. This is corroborated by the excavations now being conducted in the ruins of Teotihuacan, the greatest city known to us from Toltec times, where some marvelous structures have been unearthed. ${ }^{54}$ The temple in question is said by Sahagun to have been built in honor of Quetzalcoatl, and included in its embellishment some of the most precious work of which they were capable.

It had four halls. The eastern one (had the walls) covered with plates of gold, and it was called the golden hall or house. The western hall was called the hall of emeralds, or turquoises, because inside they had (the walls) covered with fine stonework, with all manner of stones, all placed and joined (together) as a coating or covering, like work of mosaic. The southern hall had the walls of divers marine shells, and in place of any other covering, they had 
silver, which was put together so nicely with the shells that the joints were not visible. The fourth hall, the northern one, had the walls made of colored jasper and shell, put on in a very ornamental manner..$^{55}$

The fame of this temple or palace seems to have been firmly established, as Sahagun recurs to it in another part of his history, but in less detail. Sahagun follows the fortunes of the culture hero while he was in the ascendency in Tula, and states that later, owing to circumstances which it is needless to relate in this place, Quetzalcoatl determining to abandon Tula, ordered the burning of "all the houses that he had made of silver and shell, and furthermore commanded that other precious things should be buried in the neighboring hills and ravines." 56 This indicates that the mosaic-decorated building was laid in ruins, and part of the treasure, at least, was buried before the inhabitants left the region and commenced the migration southward.

In presenting the tradition of this migration of Quetzalcoatl, Sahagun states that he (Quetzalcoatl) is reputed to have made and erected some houses underground which are called Mientlancalco. This of course refers to the famous ruins of Mitla, and seems to be an authentic tradition of the Nahuan origin of this important city of southern Mexico. It is doubly significant, when considered in connection with the description of the mosaic-decorated buildings in Tula, for, as is well known, the dominant architectural feature of the Mitla group of structures is the mosaic treatment of many of their outer and inner walls.

It is not necessary to give more than brief attention to this application of mosaic-work in architecture. The traditional mosaic-decorated buildings of Tula have disappeared, but the structures of Mitla are still standing in an excellent state of preservation, and moreover are easily accessible to travelers by rail and automobile; therefore they have been visited and admired by more people than perhaps any ruins in ancient America. In the embellishment of the walls a true mosaic 


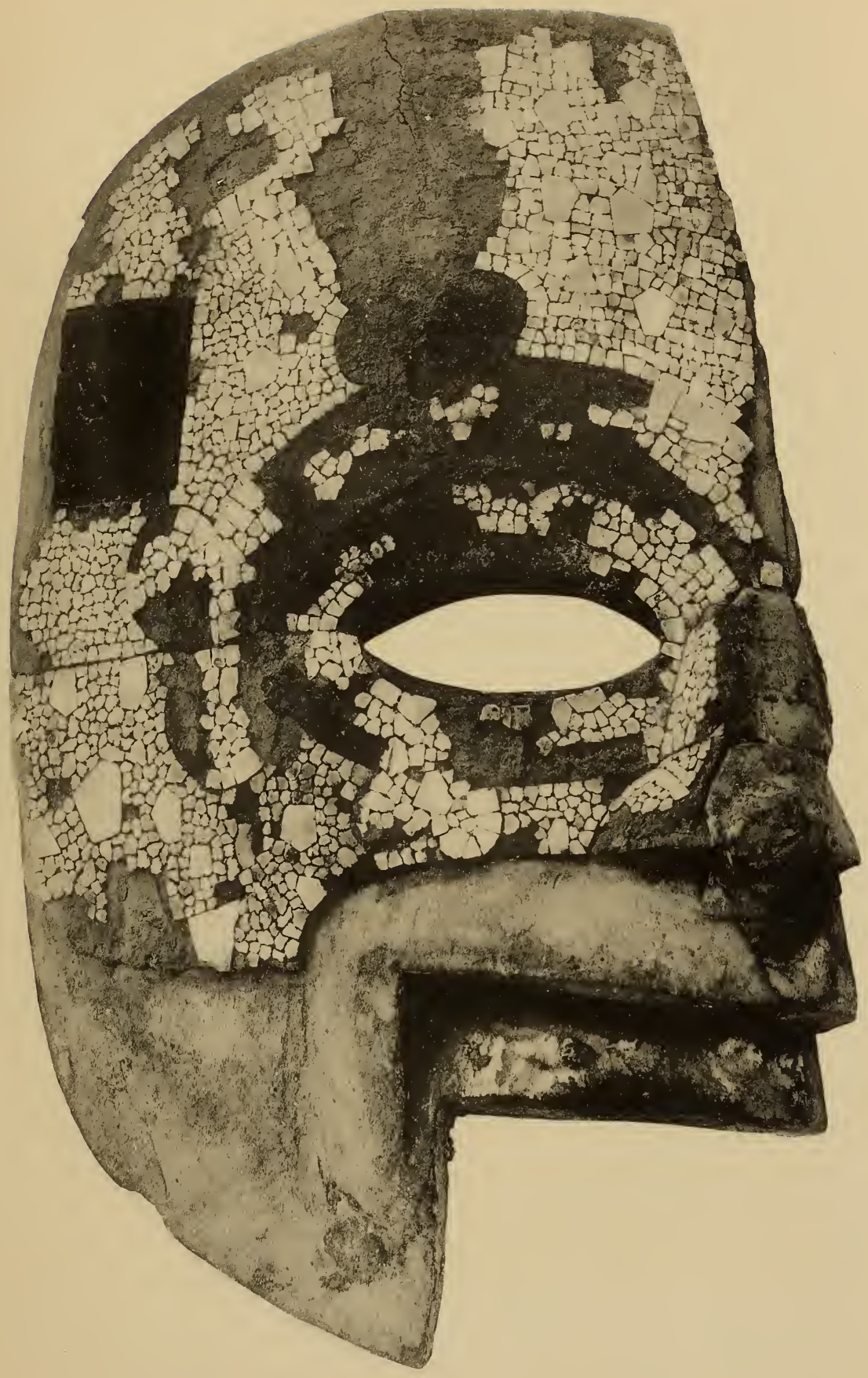

MASK OF WOOD (FRAGMENT) WITH MOSAIC DECORATION 
decoration was employed, differing in kind only from the turquois mosaic on small objects. Geometric patterns were produced by fitting together small stones of different shapes and sizes, some of which were more deeply imbedded than others, so that the designs were traced out by the stones which projected more than others; in single panels, several planes were necessary to bring out the desired patterns. In many cases the stones are so neatly fitted that the joints can hardly be traced. We have written elsewhere that-

the massiveness of the construction and simple and chaste ornamentation place the Mitla structures in a class unapproached by any other existing ruined edifices in ancient America. The workmanship revealed in the stonework, the elegant precision with which the stones are laid and carved, is not equaled in any of the Mayan ruins. However, as noted by Holmes, the geometric fretwork mosaics differ from the great façades of the Mayan buildings "in subject matter rather than in kind, for the decorated surfaces there, though depicting animal forms, are mosaics in the sense that they are made up of separate hewn or carved stones set in mortar to form ornamental designs." 57 


\section{OBJECTS DECORATED WITH MOSAIC}

IN THE ancient chronicles are found many descriptions of the employment of mosaic-work decoration in the central Mexican region. From the writings of Sahagun and others it is clearly evident that many. such decorated objects were made for and were used as parts of the paraphernalia with which great idols of wood or of stone representing various deities were adorned for the frequent religious festivals which occurred at stated intervals. The rulers and the priests and members of the socalled nobility used such objects on these occasions. The major employment of the mosaic art seems to have been for the adornment of objects or ornaments used ceremonially, such as crowns or head-bands, helmets, masks, shields, scepters, earornaments, nose-ornaments, breast-plates, bracelets, and anklets. The material on which the mosaic incrustation was placed was chiefly wood, but gold, shell, bone, and stone were also used. Small figures of the gods, either in human or in animal form, as well as musical instruments, were thus adorned. There are also indications that pottery vessels were sometimes decorated by embedding turquois in the clay.

Unfortunately we still possess only scant knowledge of the various objects ornamented in this manner. In the data obtained from the early chronicles there is abundant evidence that, in the central plateau of Mexico during the period immediately preceding the Spanish conquest, the art was highly developed. Visual evidence is at hand in the few beautiful examples now in European museums, specimens which were sent across the water by Cortés during the earliest period of the conquest, between the years 1518 and 1525 .

A few references from some of the early writers regarding the use of turquois mosaic by the Aztecs will be presented.

Stone idols were often decorated with mosaic incrustations. Andrés de Tapia describes an idol probably representing 


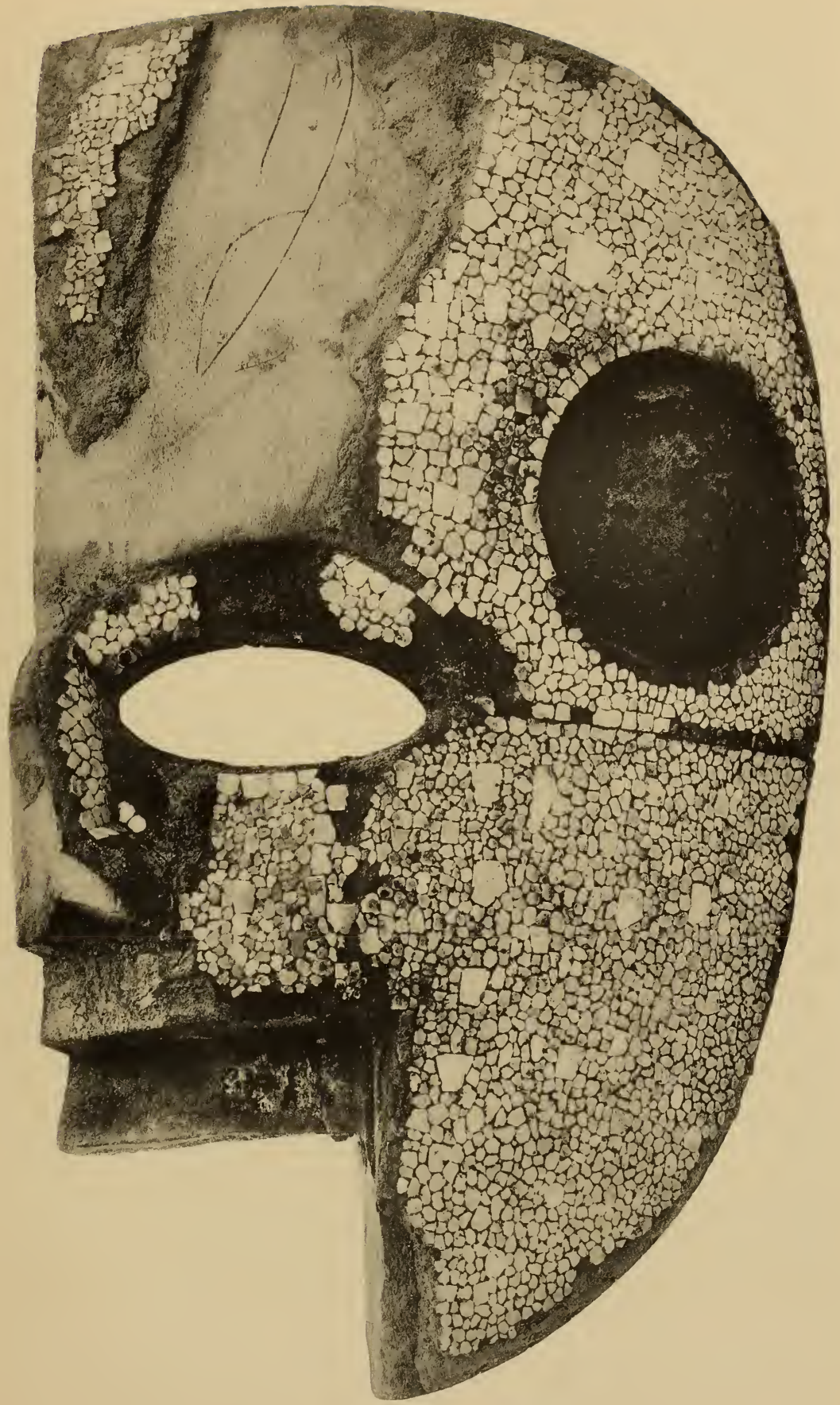

MASK OF WOOD (FRAGMENT) WITH MOSAIC DECORATION 

Huitzilopochtli, showing this type of embellishment, in the great temple at Tenochtitlan. Tapia's account is worthy of attention, for he was one of the captains of Cortés, and took a prominent part in the capture of the capital of Montezuma. He writes:

There were two idols on two pedestals, each one of the bulk of an ox; the pedestals measured a yard in height, and above these (were) two idols, each one almost three yards in height, of polished grain: and the stone was covered over with nacre, which is the shell in which pearls are created, and over this (mother-of-pearl), fastened with bitumen after the manner of paste, were (set in) many jewels of gold, and men, snakes, birds, and histories (hieroglyphs), made of small and large turquoises, of emeralds and amethysts, so that all the mother-of-pearl was covered, except in some places where they left it (uncovered) so as to make work with the stones. These idols had plump snakes of gold (as) girdles, and for collars each (one had) ten or twelve hearts made of gold, and for the face a mask of gold and eyes of mirror (obsidian or iron pyrites), and they had another face in the back of the head like the head of a man without flesh. ${ }^{58}$

Pomar describes the idol of Huitzilopochtli as of wood, "having on the breast a jewel of turquoises set in gold, with some gold bells (hanging), and on the face (were) two stripes of gold and two of turquoises, very beautifully wrought and placed." 59

In describing this idol, Bernal Díaz writes that "the whole body was covered with precious stones, and gold and pearls, and with seed pearls stuck on with a paste that they make in this country out of a sort of root, and all the body and head was covered with it, and the body was girdled by great snakes made of gold and precious stones." He goes on to mention another idol close to it, which held "a short lance and a shield richly decorated with gold and stones." 60

Concerning the ancestral treasure of the Aztecan kings which Montezuma inherited from his father Axayacatl, finally exacted by Cortés from the unfortunate ruler, Bernal Díaz de- 
scribes "three blowguns with their pellet molds and their coverings of jewels and pearls, and pictures in feathers of little birds covered with pearl shell, and other birds, all of great value. ${ }^{61}$

Tezozomoc, in describing the great sacrifices offered to the god Huitzilopochtli in honor of the coronation of Montezuma, and the presents brought by neighboring chiefs and lords as tributes from the various towns under their jurisdiction, writes:

In the center of the great square there was a building ( $x a c a l)$ where was the teponaztli, and the great tlapanhuehuetl with which they made music. On the xacal was the device of the Mexican arms with a small peñula (rock?) of painted paper, like a natural rock, with a great cactus (tuna) on it, and on the cactus a royal eagle having in its claws a great mangled snake, and the eagle had a crown of doubled or twisted paper very well (made) and gilded, and (with) very rich stone mosaic-work round about it, in the Mexican custom called teocuitla amayxcuatzolli. ${ }^{62}$

At this festival Montezuma had the king of Aculhuacan attired in special raiment, which Tezozomoc describes as "a netted mantle with much rich stonework in the knots of the mantle, and with little gold bells hanging from the fringe. ${ }^{63}$

According to Sahagun, Xiuhtecutli, god of fire, wore "earrings in the holes of the ears worked with mosaics of turquois. . . . In his left hand he carried a shield with five greenstones called chalchihuite, placed like a cross on a round gold plate, which nearly covered the whole of the shield." 64

Chalchihuitlicue, goddess of water, fountains, and rivers, wore earrings of turquois fashioned in mosaic-work. In describing the idol of Quetzalcoatl, Sahagun says that, for ceremonial occasions, ear-ornaments of turquois mosaic were placed on it, and "in the right hand was placed a scepter like a bishop's crosier or staff, the upper part crooked like a bishop's staff, and wrought with stone mosaic-work." In treating of the presents sent to Cortés by Montezuma we have already given the description of the paraphernalia pertaining to this deity. This 


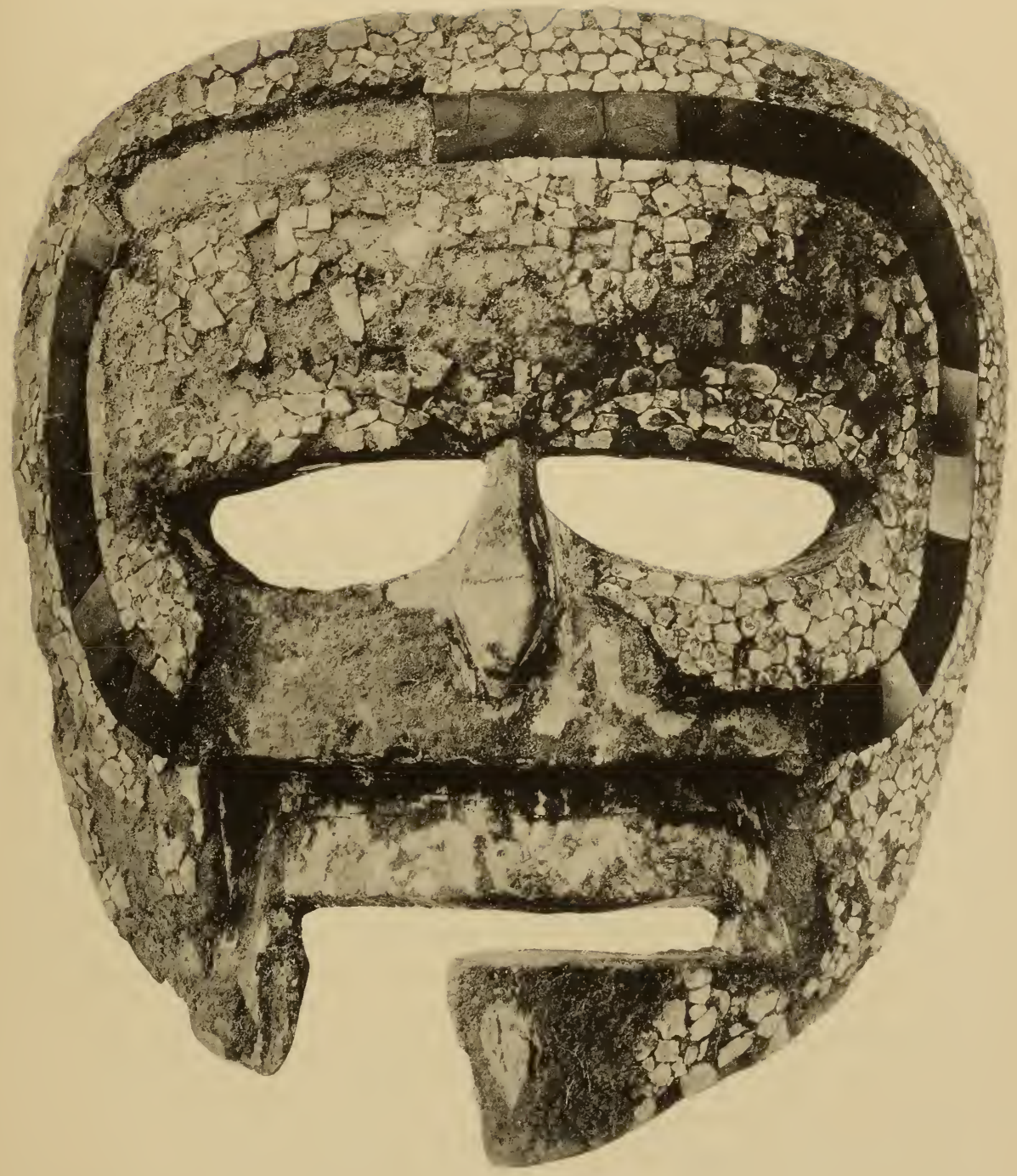

MASK OF WOOD WITH MOSAIC DECORATION

MUSEUM OF THE AMERICAN INDIAN HEYE FOUNDATION, NEW YORK 

scepter is there described as having "the crook like the head of a snake turned around or coiled." In the codices the god or his priest is represented with this staff with a crook, but the serpent-headed scepter is shown by Sahagun (manuscript of the Real Palacio, Madrid, estampa viI, fig. I) as part of the ceremonial outfit of Huitzilopochtli (fig. 5). The body of the serpent is painted blue, representing the scales done in turquois mosaic.

In describing the god Tezcatlipoca,

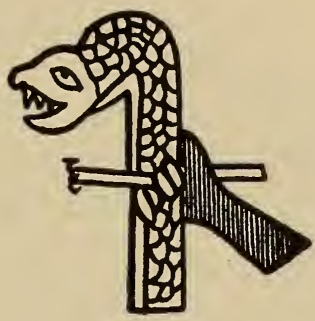

FIG. 5 Pomar states that he was represented with "a mask with three stripes (vetas) of espejuelo (either transparent lamellated gypsum [selenite], or more probably obsidian), and two of gold, which crossed over the face." 65 The idol was fashioned from wood in the figure of a man. Espejuelo, he states, was a kind of shining metal called tezcapoctli.

In the invocation to the god Paynal, which has been preserved to us in the original Mexican tongue by Sahagun, is the strophe, "yxiuh chimal, xiuhtica tlatzaqualli chimalli imax mani," which has been translated by Seler, "the blue shield, covered with the turquois mosaic, hangs from his arm . . . he carries the (blue mosaic) shield." ${ }^{66}$ This chapter was copied by Seler from the manuscript in the Real Palacio, Madrid. In the reproduction of the pictorial part of the manuscript published in colors by Troncoso, we find the representation of this deity, in which the mosaic shield is graphically drawn and painted blue (see our fig. 70, p. I7). Sahagun (book I, chap.2) briefly describes "this god called Paynal, who was a kind of under-captain of Huitzilopochtli." $\mathrm{He}$ is said to have been a man adored as a god.

The Anonymous Conqueror affords valuable information regarding the use of shields. He says:

They use shields of various kinds, made of thick reeds which grow in that country, interwoven with cotton of double thickness, and they cover them with precious stones (turquois mosaic-work) and 
round plates of gold, which make them so strong that nothing can go through them, unless from a good crossbow. Some arrows, it is true, pierced them, but could do no harm. And because some of these shields have been seen in Spain, I say that they are not of the kind borne in war, but only those used in the festivals and dances which they are accustomed to have. ${ }^{67}$

In his chapter devoted to a consideration of "the finery that the lords used in their dances," Sahagun mentions "bracelets of mosaic-work made of turquoises," and also "masks worked in mosaic, and (having) false hair such as they now use, and some plumes of gold which came out of the masks." He further describes the costumes, as follows:

They also wear attached to the wrists thick bands of black leather made soft with balsam, and decorated with a large bead of chalchihuitl or other precious stone. They also wore labrets of chalchihuitl set in gold, placed through the flesh, although they do not have this custom now. They also have these ornaments made of large rockcrystals, with blue feathers set in them, which give them the appearance of sapphires. They wear also many other precious stones protruding through openings made in the lower lip. The noses of the great lords are also pierced, and they wear in the openings fine turquoises and other precious stones, one on each side. They wear also some strings of precious stones around the neck; they wear a disc of gold hanging from a collar, and in the middle of it a plain precious stone, and around the circumference some pendants of pearls. They use bracelets of mosaic-work made of turquois, with some rich feathers which come out from them higher than the head, and bordered with rich plumes and gold, and some bands of gold which rise with the feathers. ${ }^{68}$

The distinctive head-band or crown worn by the Mexican rulers is mentioned by numerous early writers and illustrated in many codices. It was known as the xiuhtzolli or xiuhuitzontli, and was called also copilli. We have selected for illustration (fig. 6) two examples from the codices. The first $(a)$ is taken from the Sahagun manuscript of the Real Academia de la Historia, Madrid (estampa XVII). This page contains pictures of a number of Aztecan rulers, all represented with the turquois- 




MASK OF WOOD WITH MOSAIC DECORATION

MUSEUM OF THE AMERICAN INDIAN HEYE FOUNDATION, NEW YORK 
mosaic crown painted blue. Moreover, the hieroglyphic name of Montezuma, here placed above his head, is a mosaic crown. The crown itself was of gold, on which the turquois mosaic was placed. The other example $(b)$ is from the Tribute Roll of Montezuma (Peñafiel edition, pl. XIX). It is part of the

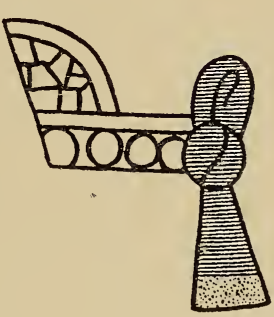

$a$

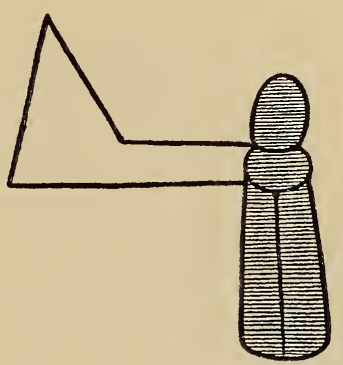

FIG. 6 $b$

hieroglyph for the place-name Tecmilco, signifying "the lands of the royal crown," the combination being the crown painted blue resting on the sign for cultivated land. Our figure shows a plain gold crown, but it is painted blue in the codex.

A copper crown from Tenango, State of Mexico, has been figured by Peñafiel. It is properly a head-band with a triangular projection with rounded top which rose from the forehead, and was probably worn by a warrior or sub-chief. ${ }^{69}$ In this work Peñafiel illustrates the mask in Rome (see our pl. vir), and states that the upper part is a xiuhhuitzolli, or turquois-mosaic crown. We will discuss this point later. Many years ago, in Mexico, the writer heard of a gold copilli as having been found in the Matlaltzincan region near Toluca, but was never able to verify the story. A few extracts from the chroniclers, relating to these golden crowns with turquois mosaic, follow.

In the Codex Cozcatzin the Aztec king Axayacatl is represented with the xiuhuitzontli, the turquois mosaic-work headband. ${ }^{70}$

In the selection of Ahuitzotl as king, Tezozomoc writes:

They put on him the crown which was blue, of rich stone mosaicwork, (in shape) like a half miter called xiuhtzolli (or xihuitzolli), and also placed on him, among other things, a netted mantle strewn with small stonework. This formed part of his costume when he 
went to the temple of Huitzilopochtli to worship. When adored by neighboring subjugated tribes he wore a crown of gold (adorned) with much stone mosaic-work of a half miter shape, and on the left shoulder was put a sash called matemacatl which was all gilded and enameled with fine stone mosaic-work, which was also called teocuitla cozehuatl, as we now speak of a shoe-ribbon, and on the foot was placed something like an anklet of acero [sic] strewn with emerald stones, all gilded. ${ }^{71}$

Duran states that among the offerings buried with the Aztec king Ahuitzotl were "crowns of the fashion that they used, of gold and of stone mosaic-work." 72

It is related by Tezozomoc that after the death of Netzahualpilli, king of Texcoco, Montezuma assembled the senate of Aculhuacan in order to select a new king. The choice fell on the fifth son, Quetzalacxoyatl. In the ceremony of investiture they placed on him "the blue crown or forehead-band decorated with stone mosaic-work." 73

The Anonymous Conqueror writes:

To guard the head, they carry things like the heads of serpents, tigers, lions, or wolves with open jaws, and the head of the man is inside the head of the creature as if it was being devoured. They are of wood covered over with feathers and with jewels of gold and precious stones, which is a wonderful sight. ${ }^{74}$

From Alonso de Molina's Vocabulario Mexicano (Mexico, I555, reprinted I57I) we are able to interpret the Nahuan words which occur in the chronicles in connection with the use of turquois in the decoration of various objects. The following are some of the more common: nacochtli, ear-plugs; tentetl, labret; yacaxuitl, nose-ornament; copilli, crown; xiuhxayacatl, mask of turquois mosaic; xayacatl, mask; cactli, sandal; tilmatl, mantle; amaneahapantli, mantle for lords richly wrought; teopixcatlaquemitl, vestment of priests; ecaceuaztli, fan; chimalli, shield; teteotl, stone idol; tequacuilli, large stone idol or statue; xiuitl, turquois; tlaquauac xiuitl, hard turquois; xiuhtomolli, turquois; omichicauaztli, bone musical instrument; ayacachtli, rattle. 


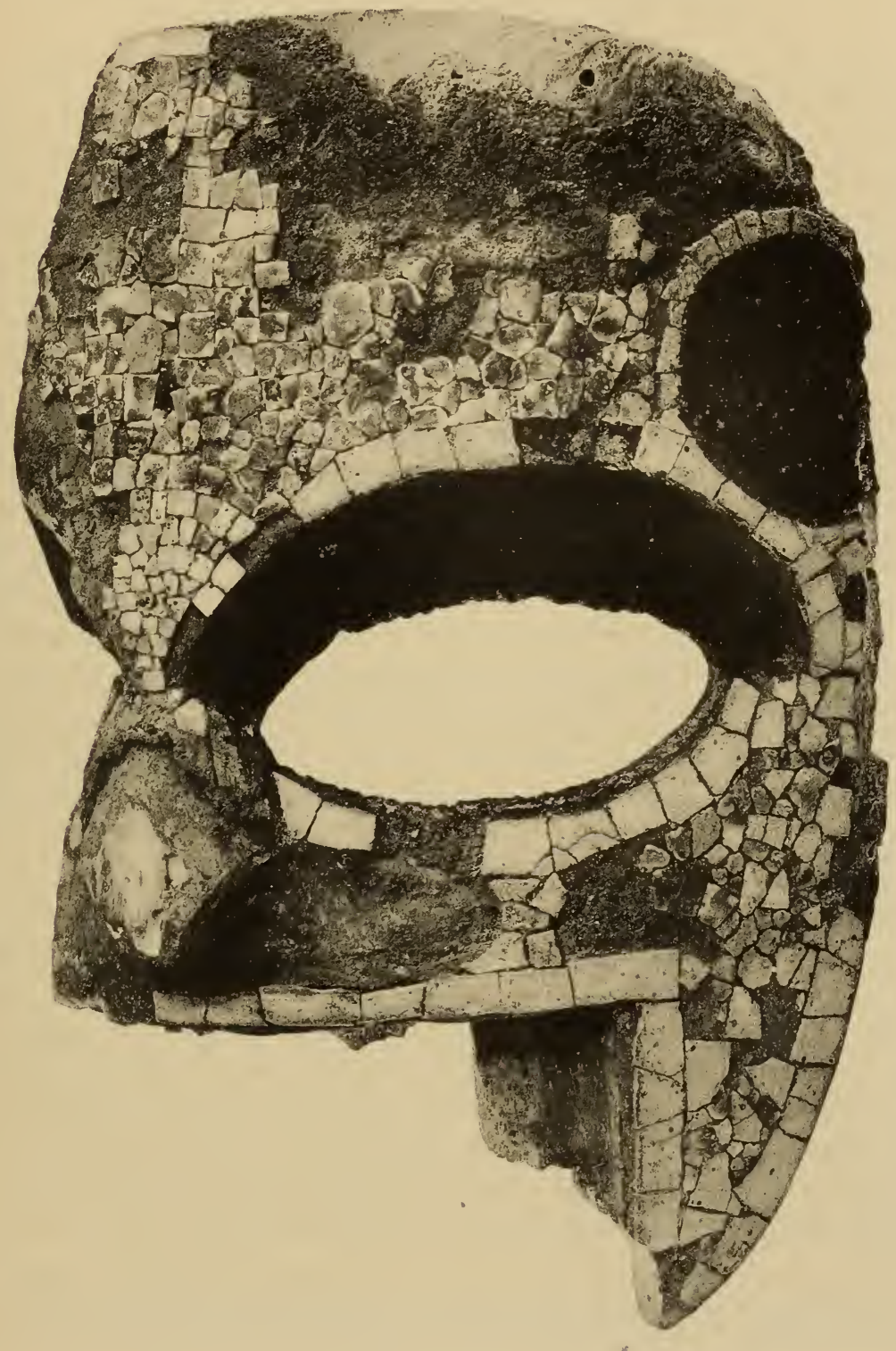

MASK OF WOOD (FRAGMENT) WITH MOSAIC DECORATION MUSEUM OF THE AMERICAN INDIAN HEYE FOUNDATION. NEW YORK 



\section{EXISTING SPECIMENS OF MOSAIC}

WE WILL now consider the existing specimens of mosaic-work. It has been demonstrated, by the extended quotations from the old chronicles and codices, that this art was considerably employed in adorning objects of a special nature in connection with the dress of kings, nobles, warriors, and priests, and the paraphernalia of the gods. We have at present no actual examples of many of the objects which we have learned were thus ornamented, consequently whatever conception we may gain by a study of existing specimens will give us an inadequate idea of the art. It is evident that the most elaborate works in stone mosaic sent to Europe, as noted in the inventories, have not been preserved, a fact borne out by the descriptions in the early accounts of the discovery and "things" of Mexico. Moreover, many of the pieces now in European museums are either in a poor state of preservation or are incomplete.

Until recently only twenty-four major examples of mosaicwork had come to light and been placed on record by printed description and illustration. Of these twenty-three are in Europe. The other specimen was found a few years ago in a cave in Honduras, and for some time was exhibited in the National Museum at Washington, but later came into the possession of the Museum of the American Indian, Heye Foundation. The twenty-three known specimens in Europe were probably all sent to the Old World by Cortés or his companions.

Some years ago an Indian found a deposit of ceremonial objects of wood, incrusted with mosaic-work, in a cave in the mountains of the Mixteca region of the State of Puebla. These specimens, seventeen in number, are now exhibited in the Museum of the American Indian, Heye Foundation. The chief object of this monograph is to describe and illustrate this unique collection.

We are also now enabled to record and illustrate, through the 
courtesy of the officials of the Peabody Museum, Harvard University, four other objects decorated with mosaic-work. These were found in the sacred cenote at the ruins of Chichen Itza, Yucatan, and are now exhibited in the Central American hall of the Museum mentioned. This brings the number of known specimens to forty-five, of which twenty-two are in the United States, and twenty-three in Europe. These specimens are now preserved in the following museums:

British Museum, London, nine specimens.

Prehistoric and Ethnographic Museum, Rome, five specimens.

Ethnographical Museum, Berlin, three specimens.

State Natural History Museum, Vienna, three specimens.

National Museum, Copenhagen, two specimens.

Museum, Gotha, one specimen.

Museum of the American Indian, Heye Foundation, New York, eighteen specimens.

Peabody Museum, Cambridge, four specimens.

In this census are not included the minor objects with mosaic decoration, which we will also describe. Of the forty-five pieces enumerated, all but three are of wood; two are human skulls, and one a human femur. As the European specimens have hitherto been described, and in some instances their history traced to the middle of the sixteenth century, it will be necessary only to refer the student to these studies, note of which will be found in the bibliography at the close of this volume. In the present study we have assembled photographs or drawings of all of these major specimens, as well as of nearly all the minor pieces, and drawings of some of the mosaic objects represented in color in the codices. Our pictorial record is therefore practically complete.

\section{MinoR EXAMPLES}

THE use of mosaic incrustation in the decoration of stone idols is illustrated in pl. II. This stone figure, 3 feet Io inches high, came from Cozcatlan, district of Tehuacan, Puebla, and is now preserved in the National Museum of Mexico. It represents 


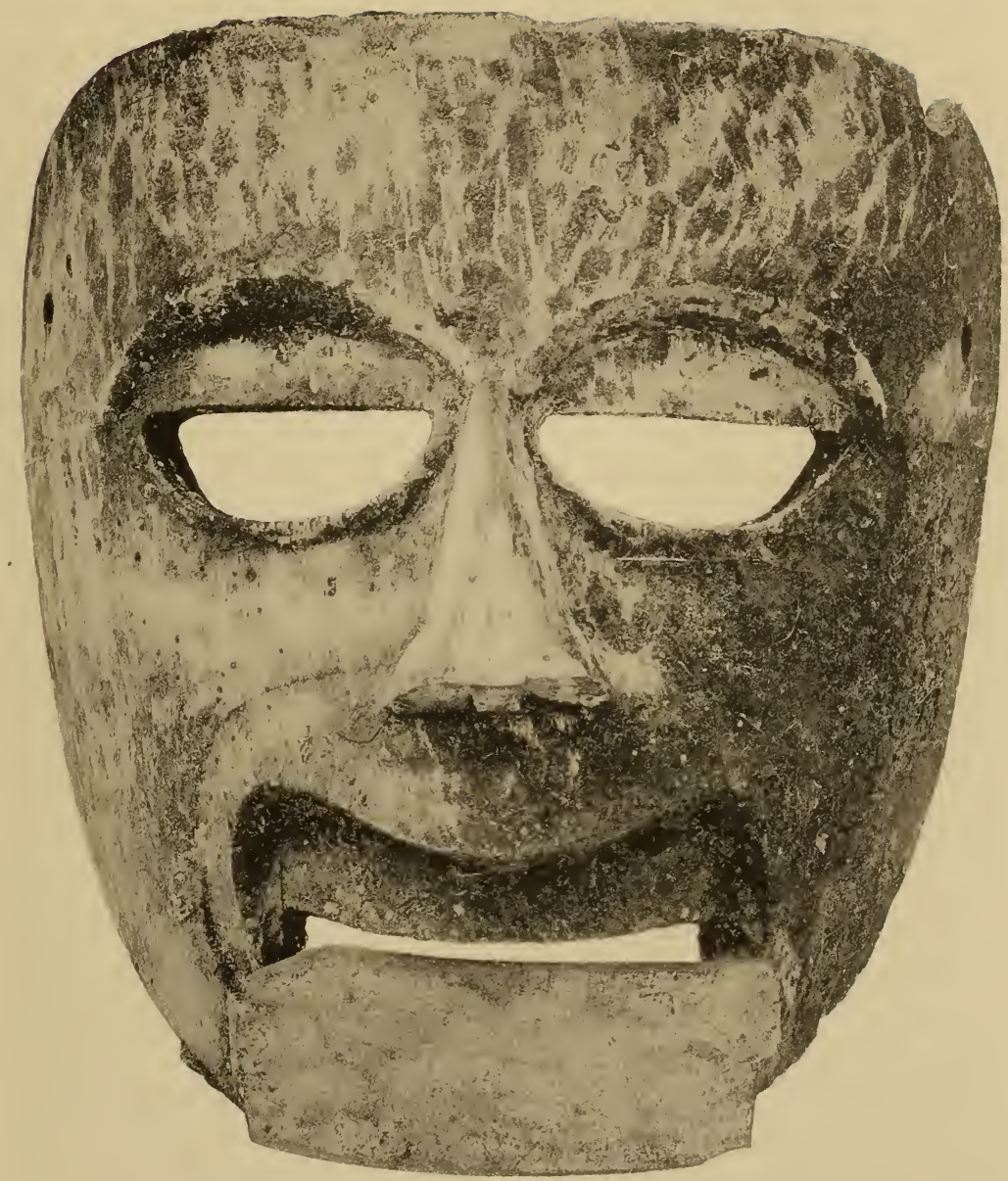

MASK OF WOOD, MOSAIC DECORATION MISSING MUSEUM OF THE AMERICAN INDIAN HEYE FOUNDATION, NEW YORK 

the goddess Coatlicue, mother of Huitzilopochtli, the Aztecan war god. The Sahagun manuscript in the Real Palacio, Madrid, represents this deity with a rattlesnake girdle around the waist; held in the right hand is a staff in the form of a rattlesnake with the head downward, and having depending feathers projecting from the rattles, which are opposite the face of the figure. Above the deity is the caption "Yztac ciuatl coatlicue." This statue, together with another, of colossal size, also in the Museo Nacional of Mexico, has often been denominated Teoyamiqui, and again at times it has been called Mictecacihuatl. The turquois decoration is still preserved in the statue illustrated, in the incrustation of the circular ear-ornaments and in the discs of mosaic in each cheek. The teeth are made of white shell; the inner part of the mouth is of red shell; the nose is inlaid with white shell. There are traces of incrustation around the eyes, but this mosaic feature is practically destroyed. In the breast is set a circular mirror of iron pyrites. Around the upper part of the forehead are small holes which probably at one time contained stone or shell inlays. A poorly colored representation of this idol has been published by Brocklehurst, with the title "Teoyamiqui, goddess of death." 75

One of the most interesting uses of turquois-mosaic decoration was in the embellishment of wooden covers for the ancient books or codices. We are fortunate in still having preserved even a single example bearing traces of this art. In I896 the Duc de Loubat had reproduced the first of his series of Mexican codices, being the first to appear in exact facsimile, even to the ancient binding. This work was Codex Vaticanus No. 3773, a pre-Columbian Nahua picture-writing preserved in the Vatican Library. In a pamphlet by Francisco del Paso y Troncoso which accompanies the reproduction is an interesting description of the book, from which we quote with respect to the covers:

It is of fine and thin wood. Each cover measures six by five inches. ... The wood of the covers is whitish, and traces of the brilliant lacquer which covered it may still be seen. . . . (One) cover bears a character which shows us that this is the point at which to begin the 
reading of the book. As in modern binding the first cover bears a lettering or coat-of-arms; so too, as a rule, the Indians indicated the beginning of their books, and placed on the first cover the decorative incrustations which indicate that here is the first page. . . . On the center of the cover, placed two in a line, are four reliefs. At first these appeared to have been made by impression on the lacquer, but Monseigneur Francisco Plancarte, who examined them with a microscope, has discovered that they are composed of a paste with which the Indians fasten precious stones in their settings, and in these incrustations we have the impress left by the inequalities of the materials once fixed on the surface. One round greenstone is left, of the kind used by the Mexicans in their mosaics; it is on the upper right-hand corner of the volume, when held ready to be opened. Below it, in the lower right-hand corner may be observed a corresponding conical shaped depression, and the remains of the lacquer in which a stone was fixed. In the other angles there is no trace of anything, proving that nothing existed there of the same kind as that which remains.

In the Loubat reproduction all these features are faithfully represented, even to the single greenstone remaining in place.

The existence of mosaic objects in the Zapotecan region of Oaxaca was one of the important discoveries made by the Loubat Expedition of the American Museum of Natural History, under the direction of the writer, during the winters of 1898 and 1902. In mounds locally called mogotes were discovered stone burial chambers in which skeletons interred with numerous offerings were uncovered.

In the burial vaults at Xoxo, excavated in 1898 , practically no personal ornaments were found, but fragments of mosaic objects were discovered in the form of bits of shell, obsidian, jadeite, turquois, and hematite, on fragmentary stucco matrices. ${ }^{76}$

In the graves and tombs at Cuilapa were discovered many personal ornaments made of jadeite, amazon stone, and turquois. In an excavation made during January, 1902 , in the great temple mound, or teocalli, dominating the group of mogotes at Cuilapa, a grave was discovered on the summit at a depth of six feet from the surface. It contained the skeleton of a child, 


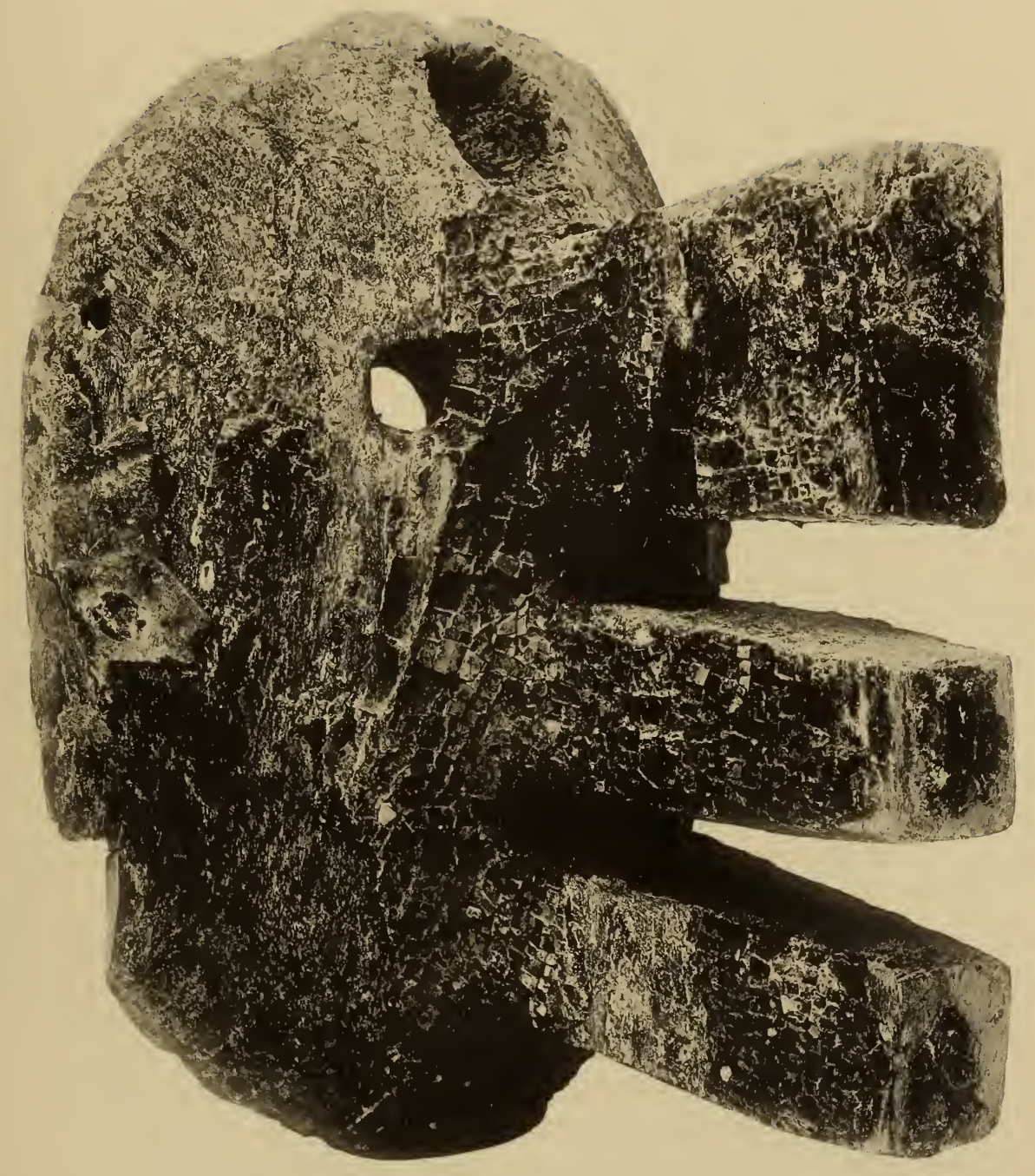

MASK OF WOOD WITH MOSAIC DECORATION FROM HONDURAS

MUSEUM OF THE AMERICAN INDIAN HEYE FOUNDATION. NEW YORK 

whose bones, together with the accompanying artifacts, were stained bright-red by hematite paint which had been thrown into the grave. Surrounding the skeleton were seventeen greenstone idols in the form of human figures; more than four hundred beads of greenstone and jadeite of varying sizes; thirty-five shells of various kinds, perforated for suspension; bits of mother-of-pearl, obsidian, and hematite, which evidently were fragments of disintegrated mosaic objects; but the most interesting objects recovered were a pair of small discs of pottery, upon the flat upper surfaces of which were cemented small pieces of very thin, highly-polished hematite, placed in mosaic. These last were undoubtedly mirrors, although from the small perforation in the center of each we are inclined to regard the pair as having been used also as ear-ornaments. One of these specimens should be in the Museo Nacional of Mexico, where it belongs; the other is in the American Museum of Natural History. The latter, now illustrated for the first time (fig. 7), is an inch and threequarters in diameter, and an eighth of an inch in thickness. Our reproduction of this interesting object has been made possible by the courtesy of Dr. Clark Wissler, Curator of Anthropology.

An interesting specimen of the combination of gold with turquois mosaic in jewelry has been recently figured in colors, and described by the writer (see fig.

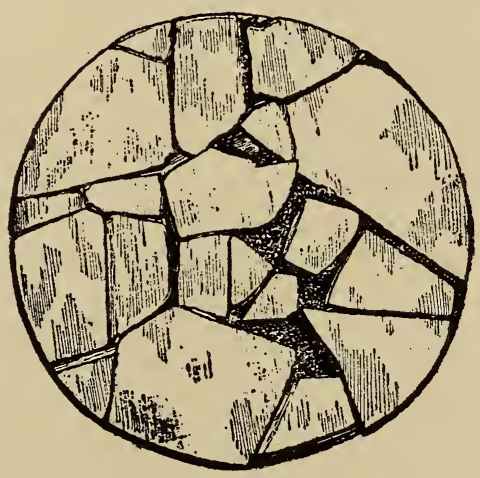

FIG. 7 8). ${ }^{77}$ It is in the form of a shield, with four arrows or darts and pendent bells, and has an extreme length of three and oneeighth inches from the top of the shield to the bottom of the central bells. We have described in detail the meaning of the hieroglyph formed by the mosaic-work, and shown that the brooch-like jewel was the insignia of one of the four principal 




FIG. 8

chiefs of the Aztecan army, who governed one of the four wards, or calpullis, into which Tenochtitlan, the capital of Montezuma, was divided. As a matter of fact, the jewel was found in a grave in Yanhuitlan, in the Mixteca region of Oaxaca. It is the only known specimen that shows turquois set on gold, a combination to which we have called attention, in quoting from Sahagun and others, regarding turquois mosaic on crowns, bracelets, and other gold objects for personal adornment.

In the collections of the Museum of the American Indian, Heye Foundation, are three mirrors faced with highly-polished marcasite on their original matrices, apparently slate-the only specimens of this character that we have seen. Two of these mirrors, which were collected by William Niven from ancient graves near Iguala, Guerrero, are perforated for suspension, and all three average five inches in diameter and a quarter of an inch in thickness. With these mirrors were found 


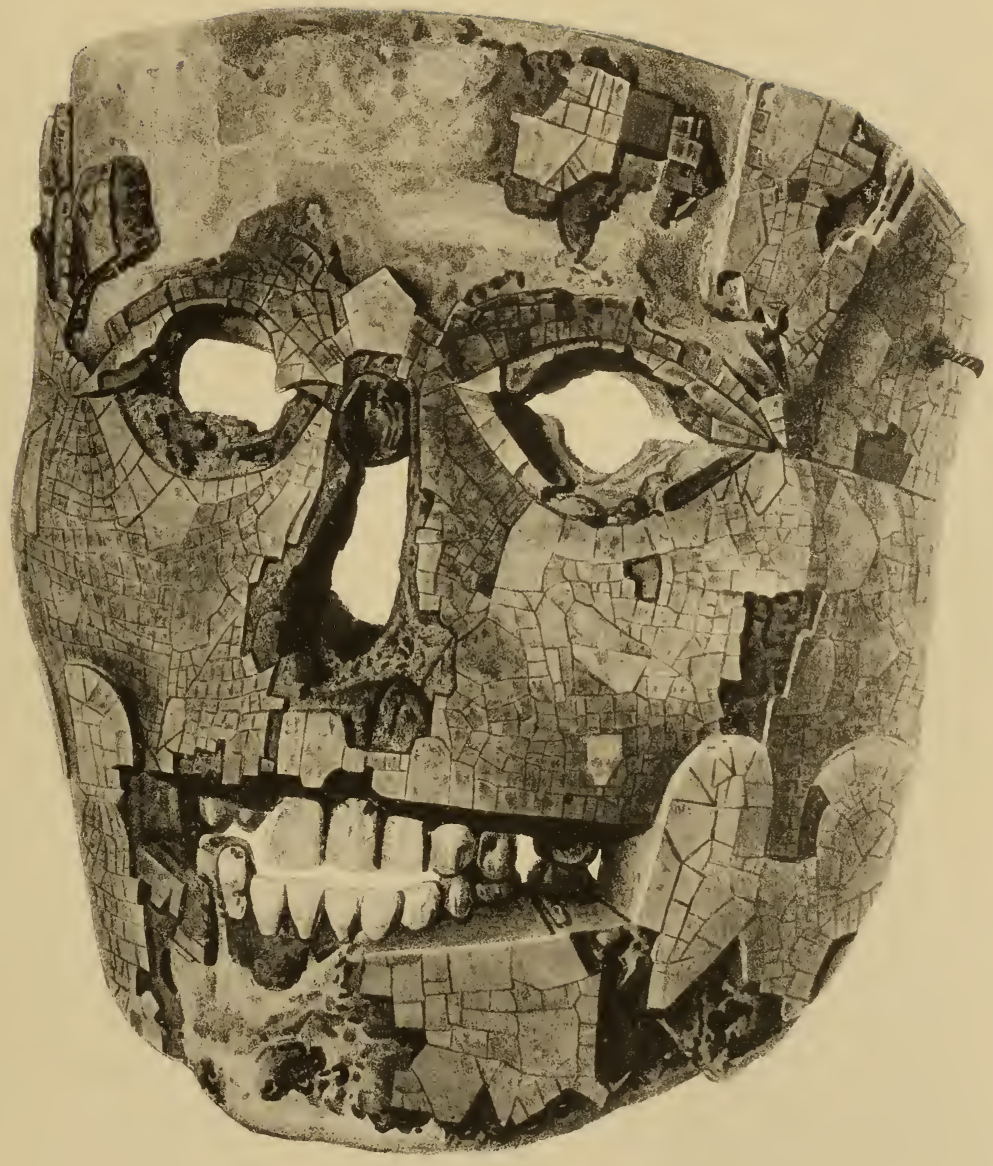

MASK OF HUMAN SKULL WITH MOSAIC DECORATION

ETHNOGRAPHICAL MUSEUM, BERLIN 

numerous little unpolished cubes of iron pyrites, which may have been intended for use in mosaic-work. There are, however, a number of rather thin, flat, irregularly shaped pieces, with very thin matrix of stone, and with beveled edges, which unquestionably have been parts of mirrors made in mosaic fashion similar to those found in the Cuilapa grave, the only difference being that the inlays from Iguala are larger and thicker than those on the Cuilapa specimens, which are simply thin sheets of hematite. The region where the Iguala specimens were discovered was probably the seat of a people of Nahuan culture.

In 1908 Dr. Manuel Gamio conducted an important excavation of an ancient building at the site known as the monuments of Alta Vista, near Chalchihuites, Zacatecas, in northern Mexico. In a large chamber called the Hall of the Columns, Gamio found two mosaics in a small circular compartment in the concrete floor. One of these was a disc of yellow pottery encircled by a ring of wood, the entire object being about two and threequarters inches in diameter and three-eighths of an inch thick. The wooden ring bore traces of a coating of resin, and many tiny bits which formed the mosaic incrustation were found with it, although not in place. The bits that had formed the mosaic were thin plates of worked turquois, beryl, and steatite. From the fact that the disc contained perforations, evidently for suspension, Gamio described it as a breast ornament.

The other mosaic piece Gamio believes to have been a labret. He writes that "at first glance its shape may be described as resembling the bridge of a violin. ... Its nucleus is wood, carved to represent two symmetrical figures of an alligator (caiman), united at the belly. Crowning the head are two head plumes, each having two branches. Above the point of union of the two reptiles there is a square projection with a perforation." 78 The surface of the ornament had been covered with small spherical plates of turquois, beryl, and steatite.

Near these two mosaic ornaments were found numerous small pieces of turquois and beryl of different shapes. 
In October, 1921, the Spanish newspaper La Prensa, New York, published a short account, received by letter from the City of Mexico, describing what purported to be an extraordinary discovery made early in the autumn. It related to the finding of a stone mask decorated in mosaic, discovered by one of the assistants of the Museo Nacional in a sepulchral chamber in Guerrero. This mask was described as being about eight inches high, the human face being partly covered with an incrustation of small pieces of turquois, with small bits of coral shell above the eyebrows and below the nose. Each eye was formed by an oval piece of pearl shell, with pupils of hematite. The mosaic covering was missing from the upper part of the forehead and the chin.

The newspaper Excelsior of Mexico City, under date of October 20, I92I, published a photograph of the specimen and a detailed study of the object in a statement signed by José María Arreola, a member of the staff of the Department of Anthropology in the City of Mexico. In this statement Arreola casts doubt on the authenticity of the specimen, pointing out that none of the known pieces of mosaic-work in European collections are of stone; that the surface of the mask is polished, which would make it difficult for the incrustation to have adhered during centuries of burial; that there are no traces of dirt in the cracks between the pieces of turquois, and finally he calls attention to a strong odor of glue which pervades the object. These arguments seemed sufficient to cast serious doubt as to the genuineness of the mosaic decoration of the mask. No such question was raised in regard to the mask itself. In a brief article entitled "Una Mascara de Mosaico Falsificada," published in Ethnos (nos. 8-12, dated Mexico, Nov. 1920-Mar. 1921), the same writer categorically asserts that the specimen is fraudulent, and calls on the reputed finder, Sr. Don Porfirio Aguirre, to present the evidence regarding the exact place where the specimen was discovered in order that further excavation may be made with a view of establishing beyond question the history of such an important and unique discovery. ${ }^{79}$ 




MASK OF HUMAN SKULL WITH MOSAIC DECORATION

BRITISH MUSEUM, LONDON 

Precious and semi-precious stones were occasionally inserted singly for decorative purposes. In this respect we may simply refer, in passing, to the custom in ancient Mexico and Central America of decorating the teeth by inserting inlays in the upper incisors, turquois, jadeite, hematite, obsidian, and rock-crystal having been used in such manner. Rarely two, and in one instance three, insets have been found in a single tooth; but this form of decoration can in no sense be considered as mosaic. ${ }^{80}$

Another example of the use of turquois as an inlay is supposed to be unique. Many years ago we obtained from Don Francisco Belmar a beautiful tripod vessel supporting against the side a polychrome human figure in the round, representing the god Macuilxochitl, god of dance and sport-the deity represented with the painted design around the mouth. It is not necessary here to discuss the question raised by Seler regarding the attributes and representations of the two analogous gods Macuilxochitl and Xochipilli. The vessel here seems clearly to be Macuilxochitl, corresponding with that given by Sahagun in the manuscript of the Real Palacio, Madrid. What is of interest is the disc of turquois inserted in the clay on the upper left-hand part of the chest, unquestionably there placed to denote some attribute of the deity.

\section{Chichen ItZA Specimens}

WE will now consider some interesting examples from the Mayan ruins of Chichen Itza, Yucatan, which were found in the sacred well, or cenote, at that site. This sacred well is described by Casares in $1905^{81}$ as arousing the admiration and awe of the Indians even to this day. It is about 450 feet north of the great pyramid known as the Castillo, and a paved way, several inches high, leads to it. At the brink is a small temple. The cenote is about 150 feet in diameter; the level of the water is 70 feet below the surface, and it is 40 feet deep, with a deposit of mud estimated to be about 30 feet in thickness. Landa writes: "They [the Maya] held Cozumel and the well of Chichen 
Itza in the same veneration as do pilgrims now Jerusalem and Rome, and so they used to visit them, carrying their offerings chiefly to Cozumel, as holy places, and when they could not go, they sent them." In another place this author states that "they had the habit then of throwing into this well living men as sacrifices to their gods in time of drought, and they thought that these would not die, though they never saw them again. They used also to throw precious stones and the things they most prized. Just on the brink of the well is a small building where I found all kinds of idols in honor of all the gods of the land." ${ }^{82}$ Casares adds: "What Landa, Cogolludo, and all other writers had narrated from mere hearsay, one of the distinguished members of the [American Antiquarian] Society, Mr. E. H. Thompson, has had the satisfaction to realize, bringing to light the truth of these statements, by diligent and intelligent work, the results of which I will not mention, as that grateful and honorable task belongs exclusively to him." ${ }^{83}$

Holmes wrote in 1895 of the sacred cenote as follows:

The Sacred Cenote is larger, and more symmetrical than the other, and, occurring in the midst of the somber forest, is a most impressive and awe-inspiring spectacle. Its charm is enhanced by the weird stories of human sacrifice associated correctly or incorrectly with its history. The walls are nearly circular and approach the perpendicular closely all around. They are diversified only by the encircling ribs and pitted grooves produced by the uneven weathering of the massive, horizontally-bedded limestones. The water has a light coffee color and looks very impure. It is shallow on one side and of unknown depth on the other. A small tomb-like ruin is perched upon the brink. It is conjectured that this structure had something to do with the ceremonies attending the casting of victims and treasure into the terrible pool. There has been some talk of exploring the accumulations from the bottom of this cenote with the expectation of securing works of art or other treasures, but the task is a most formidable one and will require the erection of strong windlasses and efficient dredging apparatus. It is doubtful if promised results warrant the outlay necessary for carrying out the work in a thorough manner. ${ }^{84}$ 


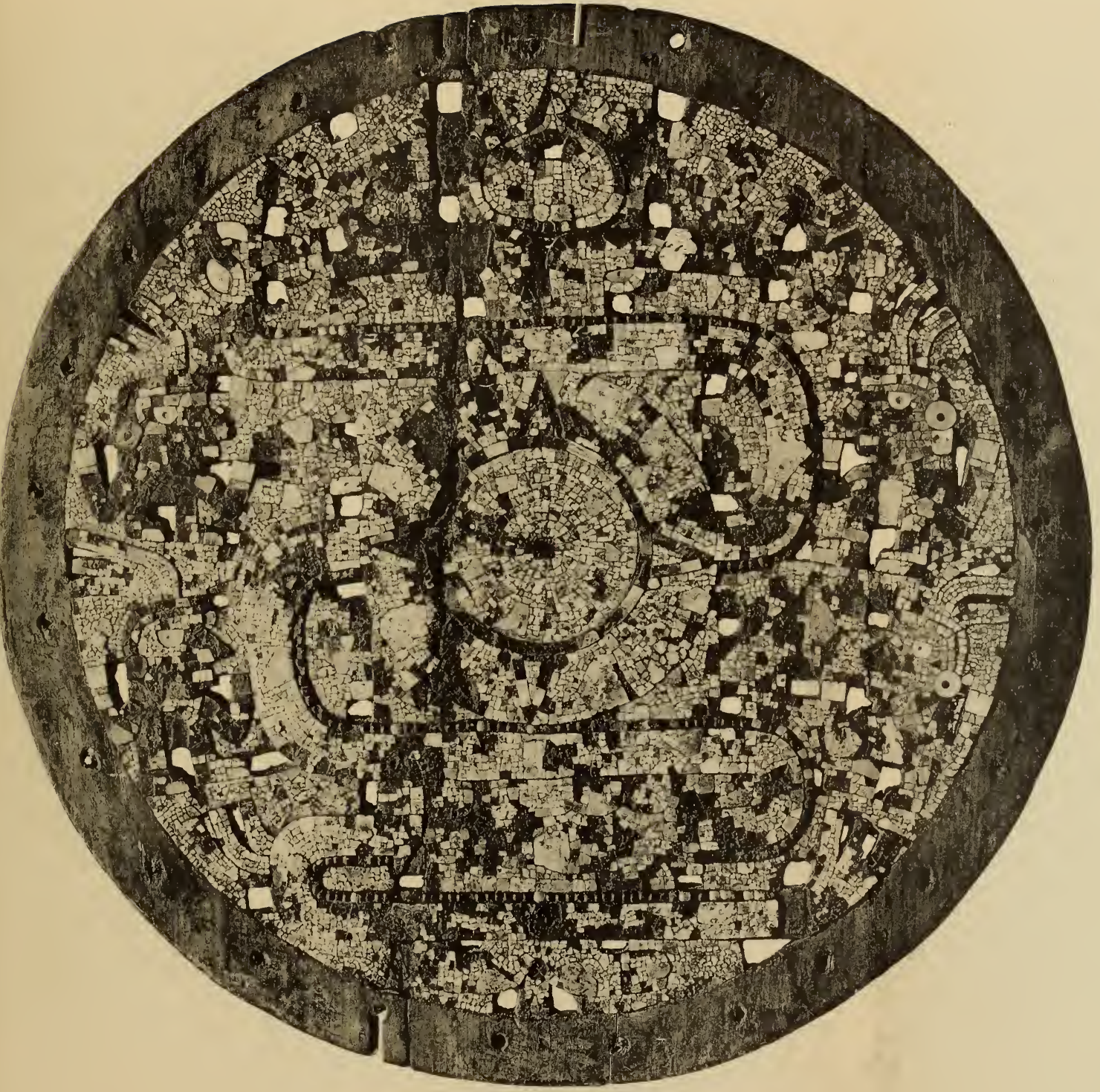

SHIELD OF WOOD WITH MOSAIC DECORATION 

Nevertheless, a few years later, as hinted by Casares, Mr. Edward $\mathrm{H}$. Thompson secured the complete confirmation of the traditions concerning the character of the cenote. $\mathrm{He}$ brought out of the mud a most amazing archeological treasure. Through the kindness of Prof. A. M. Tozzer we are enabled to include here drawings of four pieces of mosaic-work which were among the many interesting things discovered. As Professor Tozzer and Dr. Spinden are engaged in an exhaustive study of the cenote material for publication, we will not further anticipate the results of their investigations.

In figs. 9 and ro are illustrated two small fragments of wooden objects from the cenote which still retain portions of turquois-mosaic decoration. In fig. 9 the irregularly shaped piece in the center is a thin plate of gold. Both fragments are evidently from objects of considerable size. Several wooden teeth covered with the same kind of mosaic incrustation were probably from a jaguar mask or head.

Pl. III represents two fairly com-

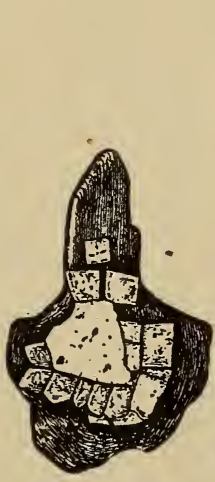

FIG. 9

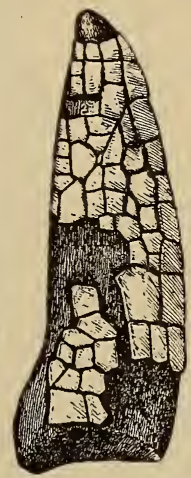

FIG. 10 lete specimens from the cenote. Of these, $a$ is a small staff or scepter, the face of which is covered with turquois mosaic, and it is possible that the headdress was once similarly incrusted. In $b$ is shown a rattle of wood, within which is a copper bell. Only two bits of turquois of the mosaic decoration remain.

In this object we find in the Mexican pictures an instrument analogous to the one last mentioned. In both of the Sahagun manuscripts, that of the Real Palacio in Madrid and the one in Florence, are representations of the deity Xipe Totec. In the former manuscript is found the name of the god written above the figure, Xippe anavatlitec, translated by Seler as "Xipe, lord of the coastland." $\mathrm{He}$ is an earth deity, "our lord the flayed," for he is represented wearing loosely about him a 
human skin. He was the patron deity of the goldsmiths of the valley of Mexico, and is said to have been paid special

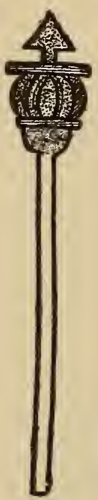

FIG. II homage by the people of the Teotitlan district, the beginning of the highway to Tabasco. In the pictures given by Sahagun, and in other codices, this god carried a long staff which terminates in a kind of rattle (fig. II), similar in shape to that found in the cenote of Chichen Itza. It was called chicauaztli by the Nahua, and Seler asserts that the rattlestick of the god Xipe was carried, besides him, only by the goddesses of the earth. ${ }^{85}$ Sahagun describes it as a scepter made after the manner of the calyx of the poppy where the seed is, with something like the point of a dart fastened in and rising from the upper part. ${ }^{86}$ The resemblance of the cenote specimen to the one shown in the Sahagun manuscript suggests that it was brought from the Nahuan region.

In the sculptured wall of the Temple of the Jaguars at Chichen Itza are represented a considerable number of warriors and priests dressed in elaborate costumes and paraphernalia. Several of these persons wear the typical triangular head-band or crown of the Nahuas, on which may be distinguished turquois-mosaic decoration (fig. 12). Two of these priests or


FIG. I2

warriors have their faces covered with unmistakable turquoismosaic masks (figs. I3, I4) ${ }^{87}$ This points to Nahuan influence, and we have other instances of this influence both at Chichen 


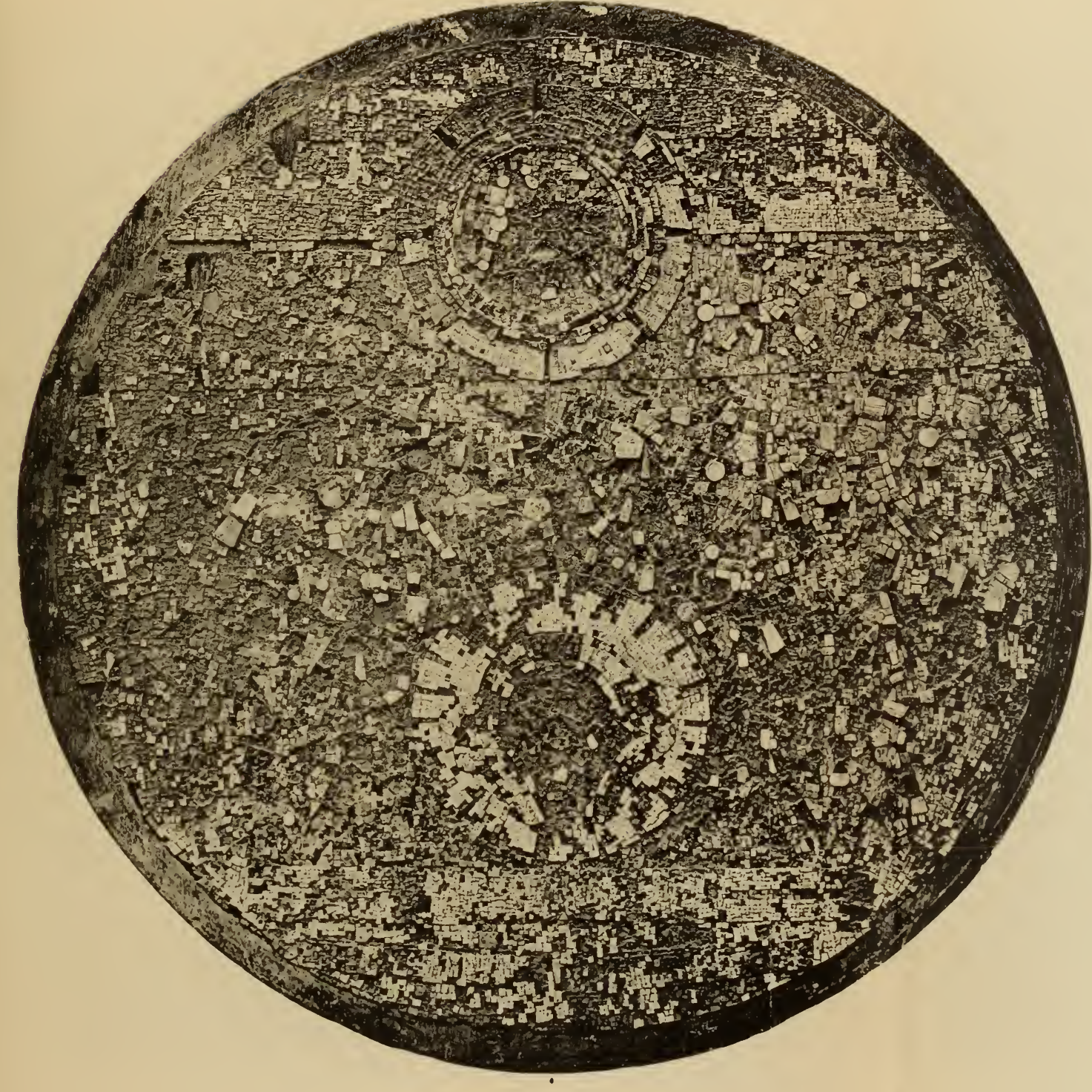

SHIELD OF WOOD WITH MOSAIC DECORATION

STATE MUSEUM OF NATURAL HISTORY, VIENNA 

Itza and at Uxmal. We are thus led to the belief that the mosaics recovered from the cenote were brought to Chichen Itza from Nahuan territory.

Another example of a turquois mosaic mask in stone sculpture is found at the back of the pro-

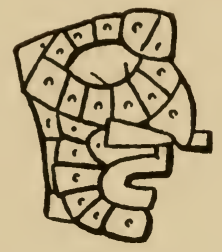

FIG. I3

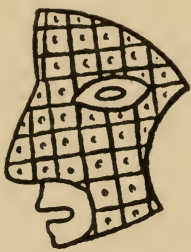

FIG. It

file face, in front of the ear, of the human figure carved on the front of stela I I at Seibal, in the region of the upper Usumacinta, Department of Peten, Guatemala. It was photographed by Maler in 1895 , and illustrated and described by him in his monograph, Explorations of the Upper Usumatsintla and Adjacent Region (Memoirs of the Peabody Museum, Harvard University, vol. IV, no. I, Cambridge, 1908). Morley has deciphered the date on this stela as IO.I.O.o.o, corresponding approximately, according to his method of correlation, to $590 \mathrm{~A}$.D. It appears to have been a hotun-marker, or stone erected every five years, and is placed in the Great Period of Mayan civilization.

\section{MAjOR EXAMPLES}

The more important major specimens now remain to be considered. As all these objects are of wood, with the exception of numbers 3 and 9, we will not repeat this in our descriptions. They are:

I. Helmet or head-piece

2. Wooden masks

3. Skull masks

4. Shields

5. Ear-plug

6. Animal figures

7. God figure

8. Knife handles

9. Human femur musical instrument. 


\section{Helmet}

The helmet or head-piece on pl. IV is in the British Museum, and was first described and illustrated in colors in 1895 by Sir Charles Hercules Read. From his study we take the following notes: ${ }^{8}$ The helmet is hollowed out inside to fit the head and is painted green; the exterior is carved with two projections, perhaps intended to represent the upper mandibles of eagles. The space between the inner upper part of the two beaks and the two outer faces of the beaks bears traces of red paint. With this exception, the outer surface has been covered with a mosaic of turquois, malachite, pearl shell, and pink shell, inlaid or incrusted on a bed of dark-brown gum. A great number of the pieces of mosaic have fallen out. It contains, fashioned in dark-green malachite pieces, two involved animal figures, which Read conjectures are rattlesnakes with crested heads. Judging from the plate accompanying Read's study (no measurements are given), the specimen has an extreme height of $71 / 2$ inches and a diameter of $71 / 4$ inches. The illustration which we reproduce, as well as of the other specimens in London, we owe to the kindness of T. A. Joyce, Esq., of the British Museum.

\section{Masks}

The mask on pl. $\mathrm{v}$ is in the British Museum, and is one of the best preserved specimens of mosaic-work from Mexico. It is of cedar, the outer surface being covered with a mosaic of minute pieces of turquois, of a brilliant color beneath the eyes and on the forehead, while on the other parts the color is a poor grayish-green. The face is studded with irregularly shaped cabochon turquoises. The eyes, nostrils, and mouth are all pierced; the first are filled with oval pieces of pearl shell, each with a circular hole for the pupil. The gum surrounding the shell and keeping it in position is gilded. In the half-open mouth is a row of seven teeth of white shell set in the upper jaw. On each temple is set a pierced square of pearl shell. 


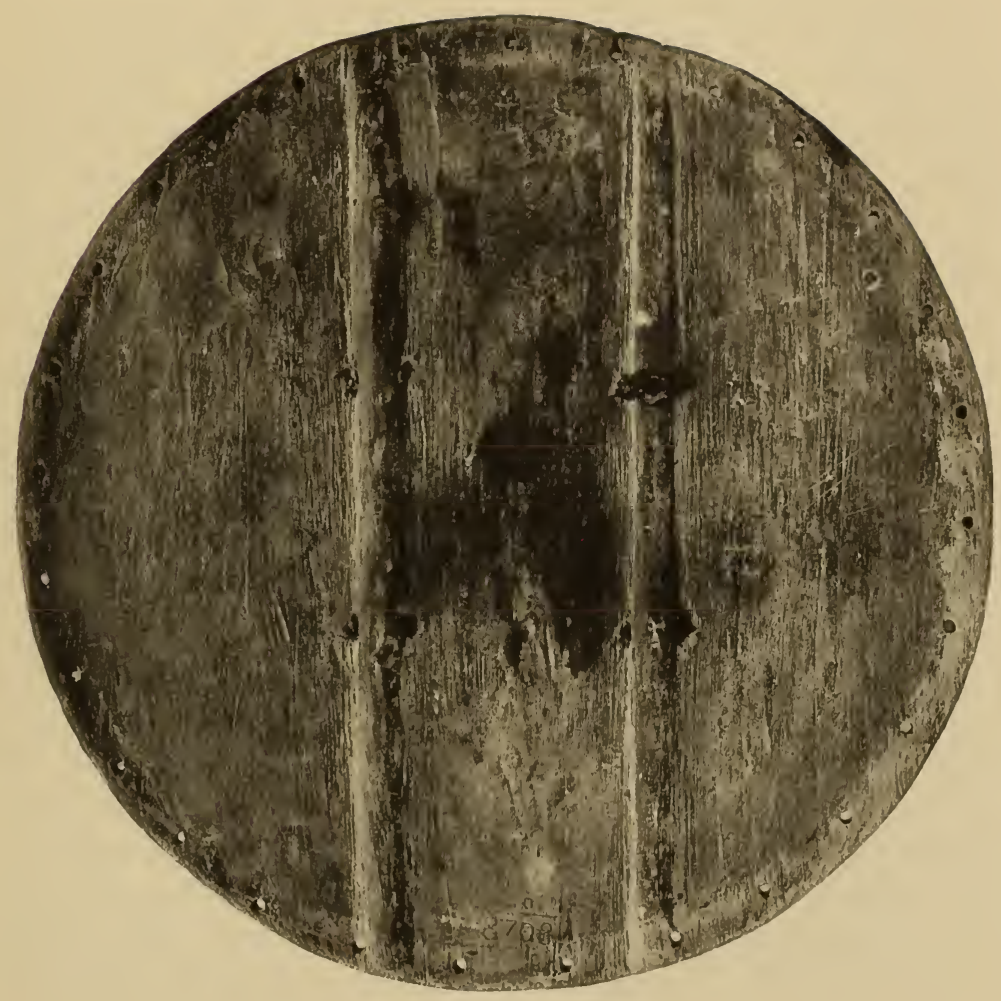

BACK OF SHIELD SHOWN ON PLATE I MUSEUM OF THE AMERICAN INDIAN HEYE FOUNDATION, NEW YORK 

The inside of the mask is painted red. Its height is $61 / 2$ inches, the width 6 inches.

On pl. vi is shown another mosaic mask in the British $\mathrm{Mu}$ seum. We follow Read's description. It is of cedar, and the lower left-hand part of the face is missing. Over the face are represented two entwined serpents curving around the eyes and mouth, and the rattle-tipped tails rest over the right and left of the forehead. The whole of the surface of the mask is covered with a mosaic of turquois, bright-blue and dull-green in color, arranged in such manner that the two snakes are distinct in color. The rattle of each snake upon the temples are modeled of the same gum as that in which the stones are embedded, and it seems possible that they were formerly gilded. The mouth of the mask is slightly open and contains teeth of white shell in the upper jaw. There is a slit over each eye and a hole in each temple. The inside of the mask is painted red. Height 6.9 inches, width 6.6 inches. Read believes that the heads of the two snakes were on the lower checks, which are incomplete. Maudslay identifies this mask with that described by Sahagun in the chapter which we have translated (see p. I4), relating to the objects pertaining to the god Quetzalcoatl which were presented by Montezuma to Cortés. ${ }^{89}$ In this description only one serpent is mentioned, and Sahagun states that "the head with part of the body came over one eye so that it formed an eyebrow, and the tail with a part of the body went over the other eye to form the other eyebrow." In the plate the two rattles are clearly seen, and Holmes has published a diagrammatic drawing differentiating the bodies of the serpents. If Sahagun's description is accurate, this specimen cannot be the one mentioned by him. It is, however, one of the most interesting pieces of mosaic that has survived.

The very interesting mask of wood shown on pl. vII is in the Prehistoric and Ethnographic Museum in Rome. It is one of the best preserved pieces in Europe, and its history is known as far back as 1553. It was purchased for the Museum by Giglioli from Cosimo de Medici for two and a half francs. It 
was first illustrated in colors by Pigorini, ${ }^{90}$ and our illustration is from a photograph just received from Rome through the kindness of Dr. S. K. Lothrop. The specimen is II inches high and $5 \frac{3}{8}$ inches broad, being the tallest mosaic mask that has thus far come to light. It represents a human face placed in what appears to be the flat open jaws of a snake or an animal, a common motive in Middle American art. The back of the mask is flat, and there are ovate openings for the eyes. From the nose hangs an ornament of a type familiar in central Mexico. Over the forehead appear what seem to be raised twined bodies of serpents, and from the left of the upper part of the face projects the plumed head of a serpent. We are unable to say if the head of the other snake once projected from the opposite side of the mask, but it seems impossible that the artist would have made this elaborate piece so symmetrical. From Dr. Lothrop's notes it appears that the turquois around the sides is of a slightly faded color, but the major portion is brilliant and glistening. The materials used are turquois, pink shell, white shell, mother-of-pearl, jadeite (for the facial lumps), and a dull-black stone. This remarkable piece is a veritable work of art, and from the serpent motive we would class it as a Quetzalcoatl mask.

The other mask in Rome (pl. vIII) was illustrated as early as 1648. This illustration, and the one published by Pigorini (fig. I 5), are front views. Our plate, from a photograph taken for Dr. Lothrop, is a sideview presenting interesting features which are not revealed in the illustrations hitherto published. The materials employed are turquois, malachite, pink shell, white shell, mother-of-pearl, an unidentifiable black stone, and garnet. The edges of the orbits and the protruding tongue are painted red, while the fangs are painted white. On the side of the face, below the right eye, is the head of an alligator, in the neck of which is set a garnet. Attention is called also to the peculiar nose and the curling tongue. A considerable portion of the mosaic is lost. This mask is larger than the masks in London and New York, being $85 / 8$ inches high, with an 


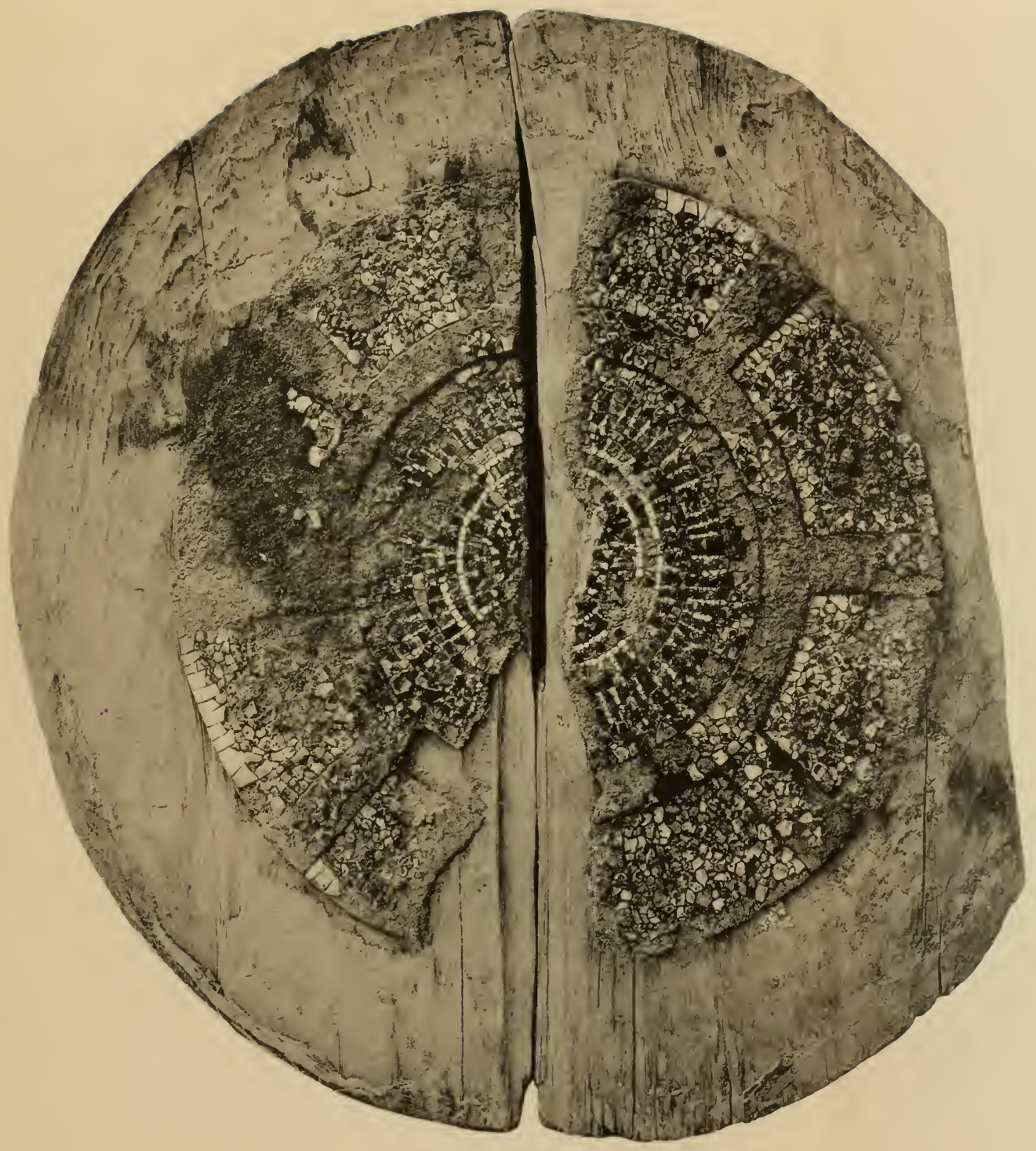

SHIELD OF WOOD WITH MOSAIC DECORATION

MUSEUM OF THE AMERICAN INDIAN HEYE FOUNDATION. NEW YORK 

extreme length, including the protruding tongue, of I I inches. Dr. Lothrop writes that in his description Pigorini has done scant justice to this remarkable piece.

On pls. IX to XVI are illustrated the series of masks from the cave recently discovered in Mexico, which are in the Museum of the American I n d i a n, H e y e Foundation. They fall into two classes, those on pls. IX to XII being ornamented with turquois mosaic, and so nearly alike in workmanship that they might well be the product of one artist, while the masks on pls. XIII to $\mathrm{XV}$ are differ-

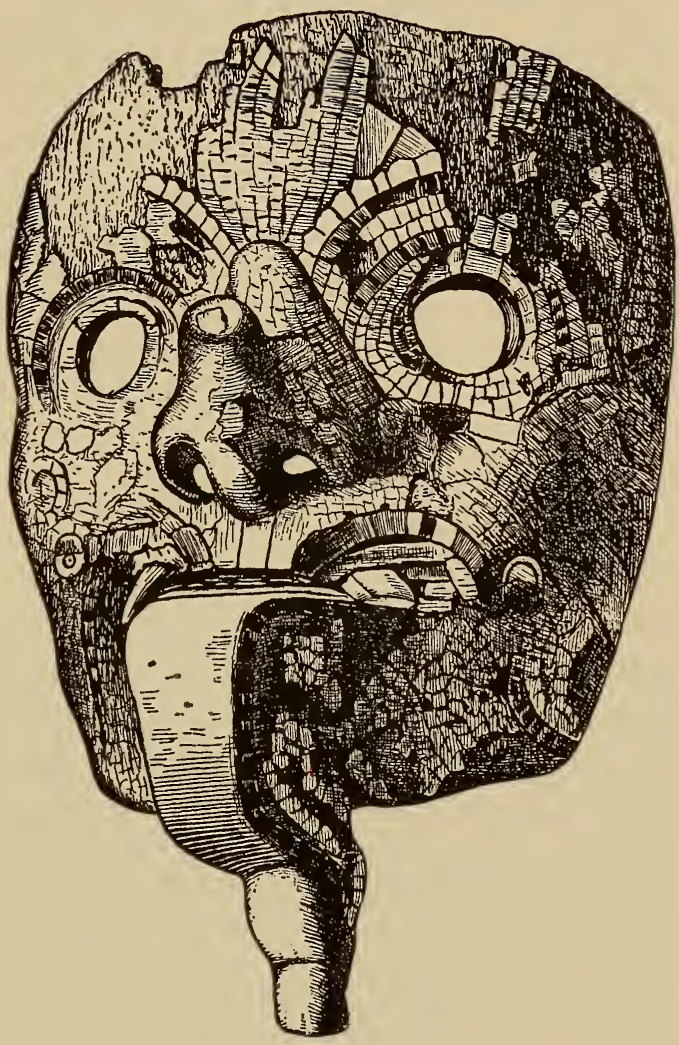

FIG. I 5 ent in character, the mosaic pieces being larger and coarser, and considerable stone other than turquois was employed in the decoration. They are all in a damaged condition and lack the chin. All the mosaic incrustations are set in a bed of gum.

The best-preserved specimen is illustrated in colors on $\mathrm{pl}$. IX; it is $7 \frac{1}{2}$ inches high, and $63 / 4$ inches wide. Bands of light and dark turquois will be observed on the forehead and temples. Around the lower margin of the face is a band of blackish to dark-brown stones. On the sides of the mask are two large 
black discs made of a composition resembling charcoal and sticky clay. This substance is present in a number of the other masks, and we venture the conjecture that it may be the material used by the goldsmiths in modeling figures to be cast in gold. Sahagun describes it as follows:

The master gives them the charcoal, which they grind very fine. And when it is ground they add a little clay, the glutinous earth which they use in their pottery. They mix the charcoal with the clay and stir it, and knead it in such manner that the two substances constitute one solid mass. And when they have the mass prepared, they shape it into thin discs which they expose to the sun. . . . For two days these objects dry, and become very hard. When the charcoal is well dried and very hard, it is cut, then carved by means of a little scraper of copper. ${ }^{91}$

The tip of the nose, as well as the chin, is gone. There are traces of red paint over the mouth and in the circular spaces on each side of the nose. When the specimen was received, the missing section of the lower part of the face was covered with a band of tin, as in the mask (pl. xvi) from which the mosaic has disappeared. From this circumstance we believe that the objects in this cave deposit were used by the Indians after the Spanish conquest, possibly until comparatively recent times. Our reasons for this belief will be found in the chapter translated from Motolinia in our conclusion. If we assume that at certain intervals during centuries the Indians resorted to the cave to worship in secret their ancient gods, we can explain the worn condition of nearly all of these specimens. Undoubtedly they were preserved and treasured for many generations, revered as precious relics of a lost but not entirely forgotten civilization. There is not the slightest reason for doubting their origin in pre-Spanish times.

The mask on pl. $\mathrm{x}$ is $6 \frac{1}{2}$ inches high and $61 / 4$ inches wide. It is quite similar to the one last described, but lacks the encircling lower marginal band. The outer zone is of light turquois, with zones of a darker shade toward the center. There are traces of red paint above the mouth and in the spaces on 


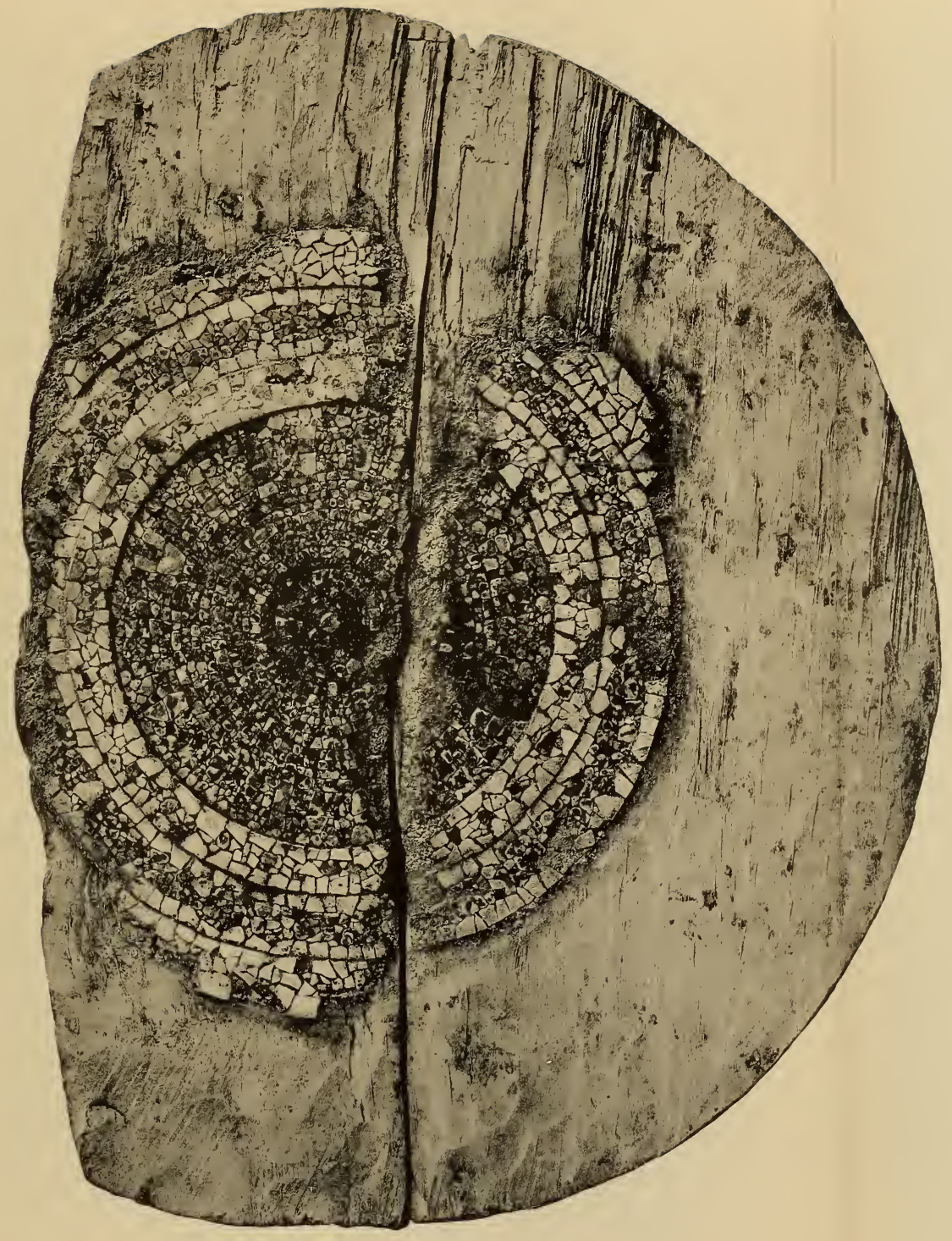

SHIELD OF WOOD WITH MOSAIC DECORATION

MUSEUM OF THE AMERICAN INDIAN HEYE FOUNDATION, NEW YORK 

each side of the nose. On the left temple are the remains of a black disc of the same material as on the other mask.

The right section of the mask on pl. XI is $7 \frac{1}{4}$ inches in height. The turquois incrustation is light-blue in color. There are traces of red paint above the mouth. The black composition inlay on the temple is square, and contains a biconical depression which does not pass through the wood. Around the eye is a raised design, possibly a serpent's body. The entire lower zone is at present without decoration, and possibly was never covered with mosaic.

The mask fragment on pl. XII is $7 \frac{3}{8}$ inches high. The small section of mosaic remaining on the forehead is dark-blue, while that on the rest of the face is light-blue. There is a black composition disc on the temple, and traces of red paint above the mouth. The marking on the plain surface on the forehead appears to be ancient.

We now come to the other group. On pl. XIII is a mask $63 / 8$ inches high and $53 / 4$ inches wide. A portion of the chin still remains, with mosaic decoration, indicating that the missing chins in the other masks were probably thus embellished. In general appearance this specimen differs widely from those just described. The pieces used in the mosaic are rougher in shape and larger. A few bits of bright-green turquois are found on the forehead, but the rest of the incrustation is a stone of a brownish- or grayish-green color. The distinctive feature is the band which encircles the forehead, running downward and ending at the sides of the nose. It is of black composition, but is highly polished, and there are pieces of light-brown color. Traces of red paint appear above the mouth.

The mask on pl. XIV is $63 / 4$ inches high and $51 / 4$ inches wide. It lacks the chin, but still retains a goodly part of the mosaic. This specimen is somewhat different in treatment from the others, closely resembling in technique the mask fragment which follows on pl. Xv. The mass of incrustation is outlined by a band of single light brownish-gray stones. The forehead has a mosaic of blackish and dark-green stones, the same effect 
being seen on each side of the plain space at the sides of the nose, merging into lighter zones on the cheeks. Red paint is above the mouth and on the spaces at the side of and below the nose. This mask had a tin band or plate over the missing chin. The space above the eyes is coated black, the material being probably obtained by thinning the black composition into a coarse paint by the addition of melted gum or wax. Two black composition discs are on the temples.

The fragment of mask on pl. $\mathrm{xv}$ is $55 / 8$ inches high. As before stated, it resembles the mask just described. The mosaic, of large bits of stone, is outlined by a line of single lighter stones. The forehead contains a mosaic of greenish stones, and the space above the ridge of the nose has a patch of light-red shell bits. The space on each side of the nose and in the mouth is painted red, while that above the eyes is painted jet black. A black composition disc is on the temple.

The mask without mosaic on pl. XVI is $67 / 8$ inches high and $51 / 4$ inches wide. The wood is of a light color, and rather soft. We have left on this specimen the tin plate which replaces the missing chin. That this mask was once covered with mosaic decoration may be seen in the fragment remaining at the right side of the mouth. The eyes in this specimen are semi-lenticular in shape, differing from the others which are either ovate or lenticular in outline.

This closes our description of the specimens found in the deposit in the cave in the Mixteca. With them were found some fragments of native paper made of amate fiber, two of which enclosed regularly shaped small masses of gum incense. In one of these several pieces of the gum were held together by an interlaced string of flexible bark. They provide further proof that the cave was resorted to for religious ceremonies or sacrifices.

The next mask to be considered, on pl. XVII, is the only specimen known from Central America, and with the pieces found recently in the Mexican cave are the only major specimens found under archeological conditions. This mask is $81 / 2$ inches 


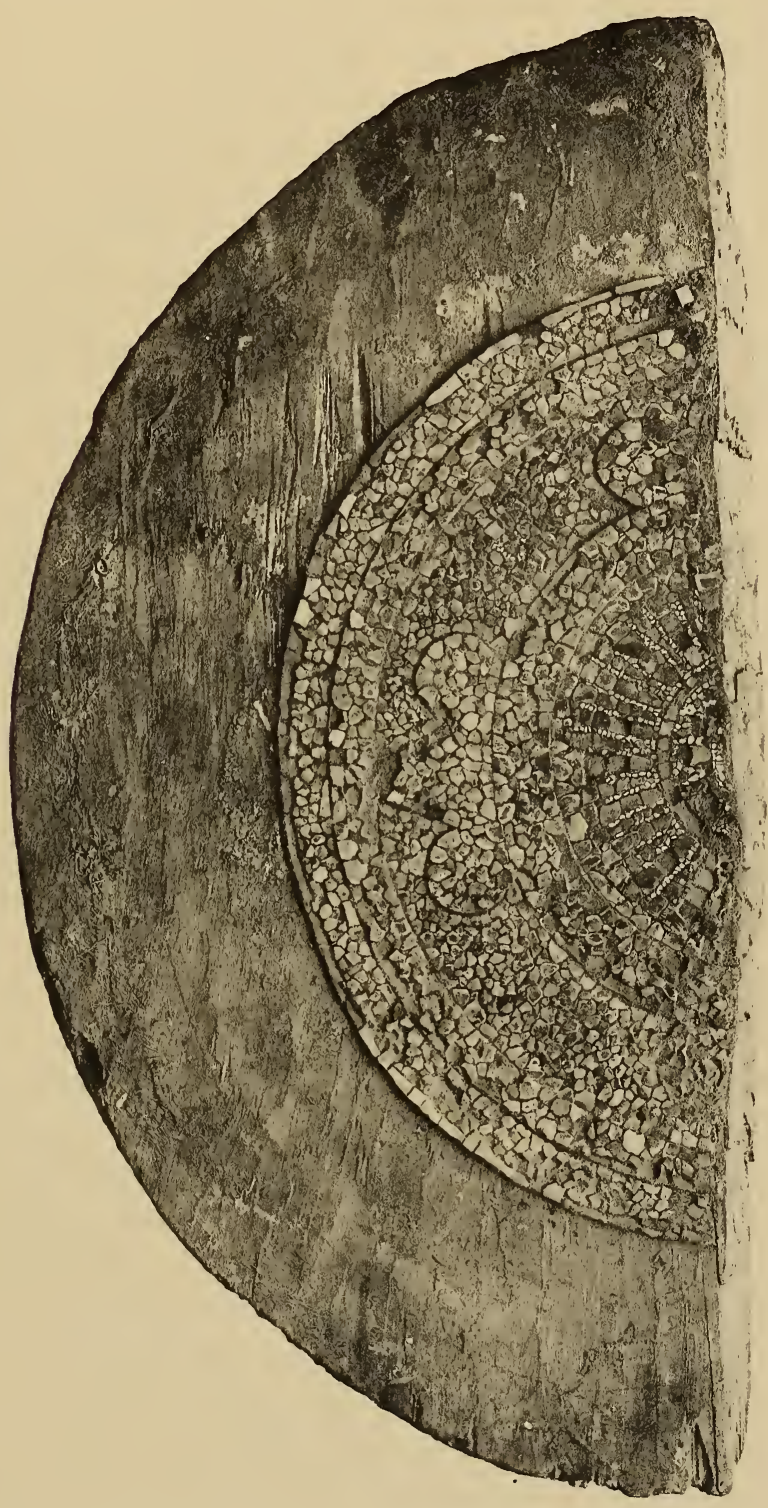

SHIELD OF WOOD (FRAGMENT) WITH MOSAIC DECORATION MUSEUM OF THE AMERICAN INDIAN HEYE FOUNDATION, NEW YORK 

high, and the three facial projections extend 4 inches from the face. It is in the Museum of the American Indian, Heye Foundation. This interesting object was found some years ago in a cave in the mountainous region of Honduras, in an arroyo on the headwaters of a small stream flowing into the Rio Chame. lecon, about 25 miles from the ruins of the ancient city of Naco. Hundreds of copper bells of varying sizes and shapes were found at the same time. The mask has been figured and described by A. H. Blackiston, whose description follows:

First in interest in the writer's collection is a large life-sized mask of white cedar which was covered with mosaics of turquois and other stones set in a thick gum or pitch with which it was coated. Three greatly elongated straight projections answer for the nose and the two lips. Holes were cut for the eyes and two small ones on the sides for the thongs which bound it to the head. A large cavity in the forehead was evidently the setting of the crowning stone of the collection, though of what nature this was we unfortunately are unable to surmise, as it evidently became loosened and dropped out years before its discovery. Along the sides of the face are depressions in the coating of gum for regularly shaped stones about half an inch long by three-eighths of an inch in width, arranged in parallel rows -none of which remain at present. The rest of the surface, as noted, was covered with small turquois mosaics, a number of which are in place today. ${ }^{92}$

\section{Skull Masks}

The two final masks to be described are the skull masks in the Ethnographical Museum in Berlin, and in the British Museum, London. On pl. xvirI is represented the Berlin example, which has been described by Uhle and illustrated in colors, threefourths natural size..$^{93}$ Only the front of the skull has been used, and it was incrusted with sky-blue to pale slabs of turquois. The mask is $65 / 8$ inches in height. Our illustration is a photograph of the lithograph published by Uhle.

The skull mask in the British Museum (pl. xIx) has been illustrated many times, and is one of the best-known pieces of 
Mexican mosaic. It has also been repeatedly described, so that it is not necessary to present a detailed description at this time. Suffice it to say that the back of the skull has been cut away, and the front covered with five broad transverse mosaic bands, alternating from the top downward, of lignite (not obsidian, as all writers have described it, we are informed by Joyce) and turquois. The inside is lined with leather, on which traces of red paint still remain.

\section{Shields}

Richly decorated shields or chimallis played a prominent part in certain phases of the life of the ancient Mexicans. Mrs. Nuttall, in her interesting and instructive study, "On Old Mexican Shields," ${ }^{94}$ has pointed out that "all authorities agree that the shields were of two kinds. The first consisted of the military shields used for protection in warfare by all grades of warriors; the second comprised the shields carried, for display only, in religious dances and festivals." In this study Mrs. Nuttall has made the following classification of shields, based on an extended examination of the chronicles of early writers:

I. Plain, unadorned war-shields (yaochimalli) of several kinds, used by the common soldiers.

2. Gala shields (totopchimalli), indicating the military rank and achievement of chiefs. These seem to have been indiscriminately used in warfare or feasts and dances. Their general structure seems to have been alike in either case, though it is obvious that they may have been more or less light and strong. Shields of this category sometimes reproduced one or more features of the military costume, body-painting and adornments pertaining to each grade. The shield in Museo Nacional is an example of this kind. Others exhibited the emblematic device of a militant god, Huitzilopochtli, Xipe, Yiacatecuhtli, etc., marking an order of chivalry - and to this division the Stuttgart specimens belong.

3. Shields, presumably of the supreme war-chief, exhibiting in picture-writing the name of his people or his personal appellation. Nothing certain is known about this group, but its existence seems vouched for by a series of indications. 


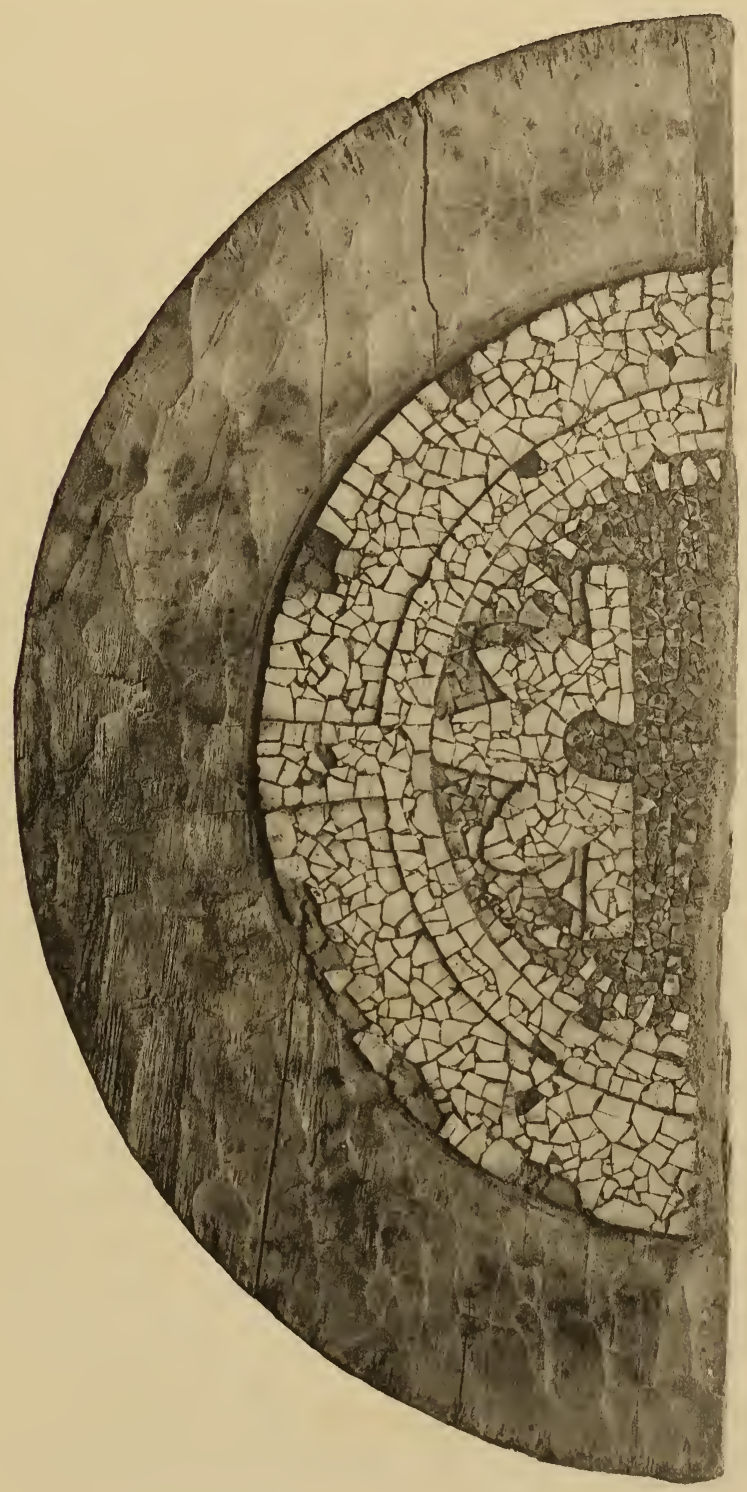

SHIELD OF WOOD (FRAGMENT) WITH MOSAIC DECORATION MUSEUM OF THE AMERICAN INDIAN HEYE FOUNDATION, NEW YORK 


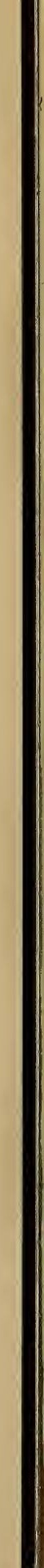


4. Shields pictured in the codices with deities only exhibiting their emblematic devices or reproducing features of their symbolic attire. Such shields seem to have been carried, in religious dances and festivals, by the living images of the deities in whose honor they were held.

5. Shields of most precious materials, with strange and elaborate designs, described in the Inventories. As they are not mentioned elsewhere, it is not possible to state anything definite about them, but it is obvious that they were intended for the use of individuals of supreme rank. The beautiful shield at Castle Ambras belongs to this group. It is, consequently, the sole forthcoming specimen with a valid, though shadowy, right to the title of "Montezuma's shield."

In the inventories of the Cortés loot, I50 shields are enumerated, mostly decorated with feathers, but 25 are specified as being ornamented with turquois mosaic, while others were garnished with gold. Of the feather-mosaic shields, one example is in Vienna (the shield formerly in Castle Ambras), two are in Stuttgart, and one is in the Museo Nacional, Mexico. Of the turquois mosaic shields, one is in London, and one in Vienna; none exists in Mexico. To this number we are now able to add eight specimens in New York, namely, one perfect shield, two nearly complete ones, and five fragments, all from the cave in the Mixteca.

We have already given numerous extracts from the early writers concerning the use of mosaic shields as part of the paraphernalia of the deities. In figs. I6-I7 are two representations of the god Paynal, holding in his right hand a mosaic shield. Fig. 16 is from the Florentine manuscript of Sahagun (lamina 8), while fig. I7 is from the Real Palacio manuscript of the same author. In the original the shield is painted blue. These are the only examples we have been able to find in the Mexican codices where the mosaic character of the shield is unquestionably delineated.

We will now consider the two mosaic shields in Europe. On pl. $\mathrm{xx}$ is the shield in the British Museum. Its early history is 
unknown, other than that it was purchased in I866 from a dealer who stated that it came from Turin. Quite a little of the mosaic is missing, but not enough to destroy the intricate and interesting designs. It has been described by Read,



FIG. 16

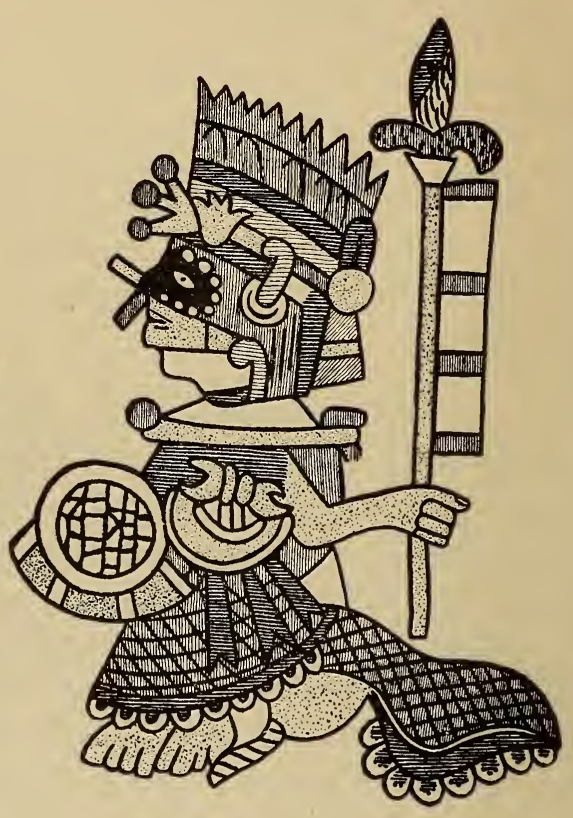

FIG. 17

accompanied with a drawing of the figures. ${ }^{95}$ The shield is of cedar, with a diameter of $121 / 4$ inches. The material used for the mosaic is turquois and shell. The center of the design consists of a circle in relief, the edge of which is divided into four equal parts by angular points in pink shell, and each quarter of the circumference has three large but irregular pieces of shell at intervals. It is a tonatiuh, or sun disc, and a figure of a serpent is disposed meander-fashion vertically over the entire central portion. One edge of the snake is bordered with imitation studs formed of brown gum, of which a few still preserve a covering of very thin gold-leaf. The head is placed at the upper left side, the tail ending in three feathers at the lower right edge 


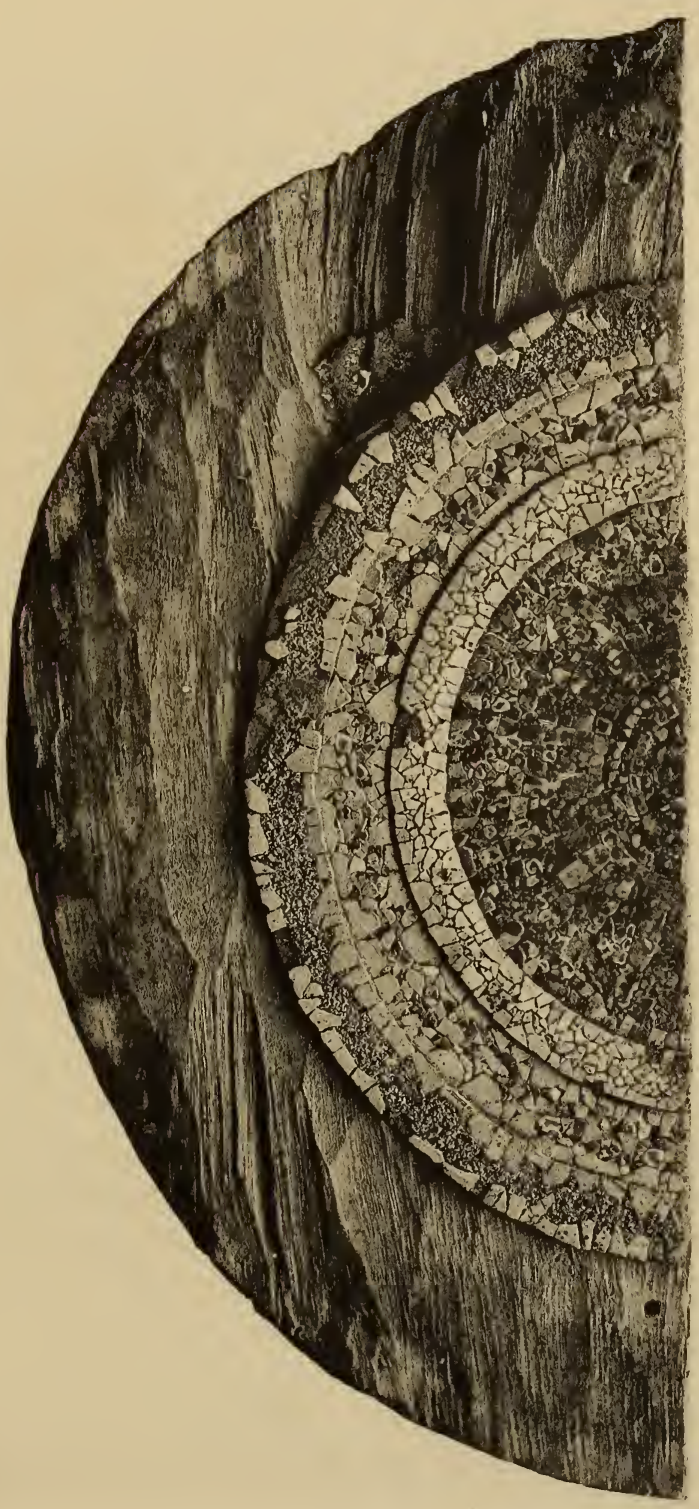

SHIELD OF WOOD (FRAGMENT) WITH MOSAIC DECORATION MUSEUM OF THE AMERICAN INDIAN HEYE FOUNDATION, NEW YORK 
. 
of the circle. On each side are two human figures, and at the center, near the top, projecting from the body of the snake, is a bifurcated design, probably a tree, upon which rests, in a pearshaped enclosure, a human figure on its back. Through the shield are many irregular perforations, and twenty-five small holes are regularly disposed around the edge, possibly for the suspension of feathers, or bits of stone, gold, or gold-leaf, over gum, may have been inserted. Two larger holes are near the upper margin.

On pl. XXI we reproduce the Vienna shield. ${ }^{96}$ It is larger than the London specimen, being $16 \mathrm{r} / 2$ inches in diameter, and the designs are not so involved as in the London shield. Unfortunately the greater part of the mosaic has fallen out, but the figures in most cases may be traced by the impressions in the gum matrix. The designs consist of two tonatiuh, or sun discs, placed one above the other. In the upper tonatiuh is a human figure. There are many examples of this motive in Mexican sculptures and codices. Across the center of the shield, between the two sun discs, is a procession of human figures, four each on the right and the left, all facing the center. Between them is a human figure, head-downward, in the act of falling or plunging from the upper sun disc. Above this line of figures are four others, two on each side of the sun disc, which they face. Below, facing the lower disc, are three other figures on each side, and lower still are two more on each side. The total number of human figures, so far as we are able to determine, is twentyfour. This shield was formerly in the Castle Ambras, near Innsbruck, and its history is traceable to I596, it being mentioned in an inventory of that date.

We cannot identify these two shields with those described in the Cortés inventories, but there is no reason to doubt that they formed part of that treasure. As examples of mosaic art, they are priceless, even in their damaged condition.

The circumstances attending the discovery of the shields now in New York have already been alluded to. P1. I is an exact reproduction in colors of one of these, the most important ex- 
ample of aboriginal American mosaic art known. It is in an almost perfect state of preservation, and is practically of the same size as the London specimen, being $123 / 4$ inches in diameter, with an average thickness of three-eighths of an inch. The wood is probably cedar. In a highly esthetic manner the mosaic incrustation has been set in a bed of gum, with alternating massing of light and dark turquoises to produce bands or zones of shading in light or dark bluish-green. It is estimated that nearly I4,000 individual pieces enter into the composition of this mosaic, the greater number being tiny circular bits. The design represents a sun disc, with eight pointers in the outer rim. Inside of the innermost of the two raised narrow encircling bands is a picture of ceremonial or mythological character. We hesitate at an interpretation, but the main features may quite certainly be recognized. We are of the opinion that the scene portrayed perhaps relates to the worship of the planet Venus. It is in the region where this shield was found that Seler, after making exhaustive comparative studies of several pre-Columbian codices, concludes:

We have to look for the home of the Codex Borgia group of manuscripts. . . . It was a land inhabited by Aztec-speaking peoples; it was conterminous with the Zapotec territory, and it lay on the trade-route which led to the coast, and to the Maya-peopled district of Tabasco. . . . Indeed we also know that in this very region astronomic observation was highly developed, and the Morning Star (Venus) held in special veneration. ${ }^{97}$

The upper horizontal band of the shield represents the celestial region. It recalls, with its feather fringe at the top and dots hanging from the lower section, the design around the socalled calendar stone collected by Humboldt, now in the Berlin Museum, and the upper encircling rim above the procession of figures of the so-called stone of Tizoc, as well as some of the upper bands in the murals of Mitla. If this is the celestial band, as we believe, it is quite appropriate to find on it the tonatiuh, or sun, represented in the rosette in the center. We find here two sets of four pointers each, radiating from the central disc of 




SHIELD OF WOOD (FRAGMENT) WITH MOSAIC DECORATION MUSEUM OF THE AMERICAN INDIAN HEYE FOUNDATION, NEW YORK 
feathers, which surrounds a lozenge-shaped piece on which is a tiny pit below two horizontal lines. In the Real Palacio manuscript of Sahagun (estampa XII) are pictures of various symbols for heavenly bodies, one being a small disc with tiny dots, explained by Sahagun as being the sign for Venus. We have endeavored to identify this glyph with that of the symbol for turquois or jewel, or the sign for chalchihuitl. There is a slight resemblance, but we hold the opinion, as before stated, that it is the sign for the sun. We have been unable to find the exact counterpart of this combination either in the codices or in sculptures.

We now come to a feature which is also found in the Vienna shield, namely, a person falling or descending from the sun or celestial regions. The injured condition of the Vienna specimen renders it impossible to distinguish the sex of the figure, but in the New York specimen a woman is represented, probably a goddess. On several pages of the Codex Nuttall Zouche ${ }^{98}$ (pp. $4,19,21)$ are representations of human figures hanging from or plunging from the heavenly band. Seler has connected these scenes with the Venus period of the Mexican calendar. Attached to the band on our shield are five dots. Taken in connection with the eight dots below, respectively four on each side of the hieroglyph at the bottom, one recalls the suggestive fact that the Mexicans were acquainted with the correspondence of eight solar years to five Venus periods, and reckonings connected with the correction of these two periods have been established by both Seler and Bowditch. ${ }^{99}$ In the Codex Selden is found an analogous picture, the band of the sky, with a central tonatiuh, and a descending human figure attached, below which are two figures. This scene has been interpreted by Beyer ${ }^{100}$ as representing the solar god accepting human sacrifice. In our shield, the feature which follows in Codex Selden, depicting this sacrifice, is absent.

In our shield, facing the plunging figure, are two human figures, one on each side, holding something like a staff in each hand, similar to those held in the hands of the goddess. From 
the mouth of each of these figures protrudes an unknown object, perhaps a conch-shell trumpet, but it is not supported by the hands.

Above a horizontal band just over the bottom of the inner encircling rim is a hieroglyph. It is the well-known glyph for Culhuacan, or Colhuacan, the name of an important town in the valley of Mexico in ancient times. The form of the glyph, a mountain with a curved peak, is derived from the tradition
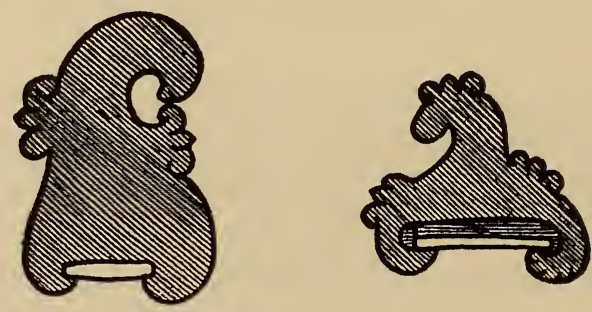

FIG. 18

that the Nahuan people originated where there was a mountain with a curved peak, called in the Nahuan language Culhuacan. The sign is interwoven with the legendary history of the ancient tribes in central Mexico, Teuculhuacan being the province far to the north where were situated the Seven Caves of Chicomostoc, the primeval home whence sallied the Seven Tribes. In the Codex Boturini I, this legend is pictured. In fig. 18 are two forms of the glyph taken from the Codex Telleriano Remensis. On each side of this glyph on the shield are four dots, not to be confounded with the representations of shells attached to the glyph. These eight dots should have a calendric meaning, and we might stretch our imagination and consider the glyph to be Calli, a day-sign and also year-bearer, represented by the conventional figure of a house, which would give us the date 8 Calli, capable of being coördinated with either the year 146I or 1513. The general character of the glyph, however, seems to be too well established as Culhuacan to admit of such hypothesis. 


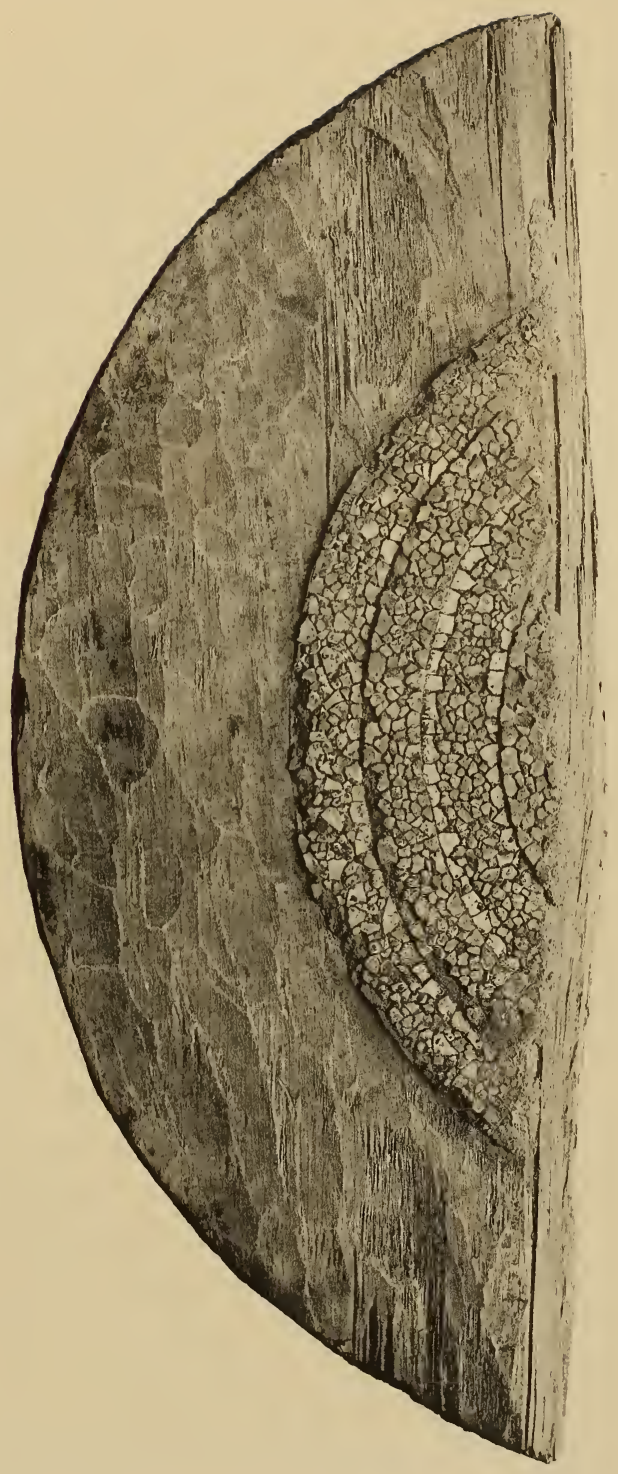

SHIELD OF WOOD (FRAGMENT) WITH MOSAIC DECORATION MUSEUM OF THE AMERICAN INDIAN HEYE FOUNDATION, NEW YORK 


\section{D}

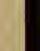


In a letter to the writer Dr. H. J. Spinden advances an explanation of the combination of the figures in this sun-disc shield. With his permission we quote him verbatim:

I am inclined to believe that the design as a whole represents a sun shield, the eight radiating bars being the rays, while the celestial band, the three human figures, and the Colhuacan glyph replace the parts of the sun's face, namely, the head-band, the two eyes and nose (the plunging figure in lieu of the nose), and the mouth. This may seem pretty far-fetched at first glance, but it is quite in the spirit of Aztec art. On the Calendar Stone, around the face of the sun god and the ollin symbol with the enclosed glyphs of the four ages, is, first, a circle of the day signs, second, a circle of quincunx figures, supposed to be the classical hieroglyphs or rather symbols of turquoises, third, a frieze of eagles' feathers. Multiple rays of different sizes complete the picture. In the actual shield before us we have the turquois mosaic, and the holes around the rim suggest that eagles' feathers may once have been attached. Compare the sun shield or sun basket of the Pueblo Indians, and the various sun shields on Mayan monuments. Now, the sun and turquois seem to be pretty closely connected symbolically - both mean divine. The hieroglyph of the sun is used for the teo, god, in place names, while the prefix xiuh means divine in connection with various objects. Jade, on the other hand, means precious. The sun in Aztec ritual is pretty closely connected with riches and jewels, and the sun disc may easily have been conceived of as a gem-studded object. I think it quite possible, therefore, that the design on this shield was intended to symbolize the face of the sun, and the fact that complete figures engaged in some ritualistic function replaces the parts of a realistic face does not detract from the theory.

The back of the shield is shown in pl. xxIr. Through the two vertical ridges are pairs of holes, evidently for the leather thongs for holding the shield. The twenty-eight small holes around the edge of the shield were probably for the insertion of feathers or other ornaments, as in the British Museum shield.

In technique our shield is similar in all respects to the two mosaic shields in Europe. In all three the incrustation is in a bed of gum that has been spread over the wood. 
We now come to the series of seven mosaic shields in New York, shown in pls. XXIII-XXIX. In these we are dealing with a different technique, and one which is new to us. For the matrix a kind of cement like fine gritty brown sand was used in place of gum. They are unfortunately in a considerably damaged state, but two are more or less complete. In these examples the wood has been roughly shaped, and in all of them the marks of the copper or stone adzes are clearly visible, for there was no final smoothing of the wood as in the three specimens before described. The probable reason for this is seen in the shield on pl. XXIII. On the face of this specimen, on portions of the lower edge, especially at the left, are traces of a coarse native paper made from the amate tree, which occurs as a band that had been glued to the wood. Traces of paper also are found in the same place on the shield fragment illustrated on pl. xxIv. It is impossible to state definitely if this paper once extended from the edge to the raised body of the mosaic decoration. On the fragmentary shield just referred to may be seen a faint black line, made with some substance like graphite, running partly around the circumference 1 to $17 / 8$ inches from the edge. It is probably the artist's line in arranging for some class of decoration, perhaps delimiting the section to be covered with paper. On the first shield no such line is found, but it seems certain that the rough wood between the narrow band of paper and the mosaic must have been covered either with paper or with some other material. There is no trace of cement, and we are led to believe that the paper once extended over the entire plain surface of the wood. Parchment or soft leather may also have been stretched tightly over the outer zones of shields which show no traces of paper. On this surface some type of decoration was undoubtedly placed. We recall the quotation given above concerning the use of turquois mosaic decoration on paper, in connection with the worship of the god Huitzilopochtli. Feather-mosaics, so far as we know, were generally made either on parchment or on paper. The codices were made either of leather, parchment, or paper, often 


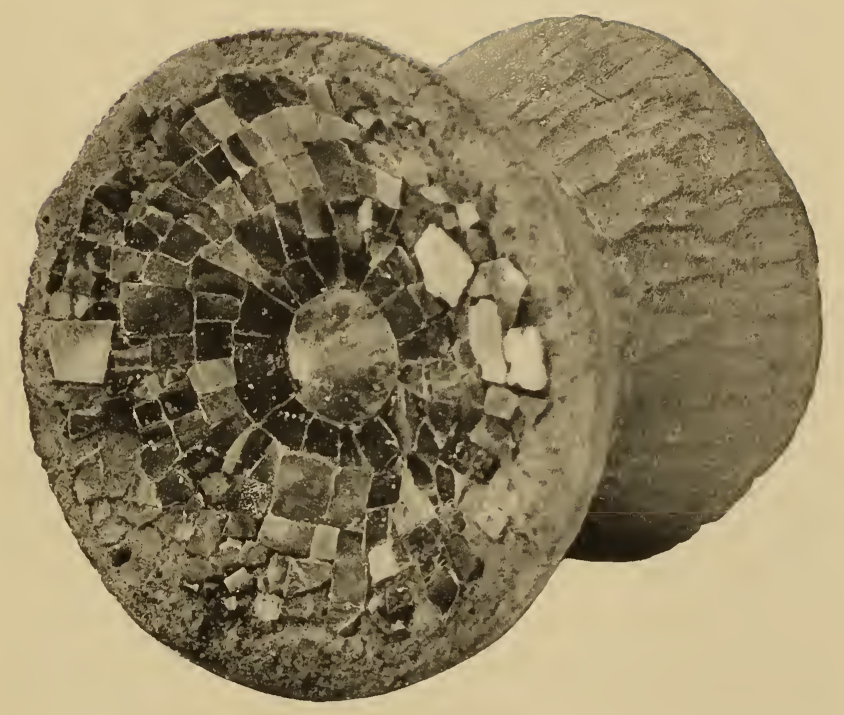

EAR PLUG OF WOOD WITH MOSAIC DECORATION MUSEUM OF THE AMERICAN INDIAN HEYE FOUNDATION, NEW YORK 

sized with stucco. In rare cases the painting was applied directly on the paper. It is undoubtedly true that one or the other of these processes of decoration completed the ensemble of the shields we are now considering.

Another point of difference in this series of shields is the material spread over the wood to receive the incrusted stones. It must have solidified slowly to have allowed for the careful and laborious work of fixing the pieces in the plastic matrix. In the case of the matrix of gum, material could have been applied and would have hardened immediately, for by tests, even after the lapse of centuries, we have found it possible to loosen the bits by the application of heat to the stone; but in the case of the cement matrix this is not possible. We do not know what liquid was used to harden the cement, which is now quite friable.

Relatively speaking, comparatively little turquois was used in this class of mosaics. Different shades of a soft light-gray stone was employed in the outer zones, while darker stones interspersed with turquois of varying shades, some almost white, and bits of lignite and obsidian, are found.

A final unique feature may be noted in the shields on pls. xxvII and xxvin. In the outer band will be observed the irregular inner edges of the two lines of stones which form the border. In pl. XXviI the space is filled in with a sprinkling of gritty, almost sand-like, bits of faded whitish-blue bastard turquois. It appears to have been spattered or sprinkled on while the matrix was very soft. In the case of the shield on pl. xxvin, the material is somewhat coarser, and consists of rough bits of the same stone used in the broad light band within the outer border.

These shields, so far as we are able to judge from the fragmentary sections, contained no pictures or figures as in the other type. In general execution they are inferior in workmanship, and less refined and finished in appearance. In fact, they constitute a quite distinct and, up to the present, unknown type of stone mosaic from Mexico. 
The first shield of this series (pl. XXIII) is in two fragments, a portion of one edge being missing. It has an average diameter of 15 inches, and a thickness of one-half to three-quarters of an inch, the mosaic disc rising one-eighth of an inch above the wood. The mosaic portion has a diameter of $101 / 4$ inches. It appears to be a sun shield, judging by the eight pointers which radiate from the band surrounding the circular design in the center, which suggest a conventional representation of the sun. In the center the darker bits are obsidian. A portion of the matrix and of the mosaic incrustation has fallen off, and on the matrix near the upper left is a greasy patch which may be candle grease.

The shield on pl. Xxrv is the same size as the preceding one, 15 inches in diameter. It is also in two sections, and a larger section of the side is missing. This likewise is probably a sun shield, but it has no pointers. Where the outer band has fallen off toward the lower part can be seen a faint incised line which the artist placed there as a guide-line in following out the circular mosaic decoration. In the center the black bits are lignite.

The next shield shown ( $\mathrm{pl}$. Xxv) consists of a half section only. It was slightly larger than any other shield in the collection, having a diameter of $151 / 4$ inches and a thickness of $I$ inch. It was a sun shield, and had four pointers identical with those on the famous calendar stone of the Aztecs. There are traces of a paper band glued around the outer edge; the black line has already been referred to. The central disc, with the white lines made of very tiny bits, is similar to the central part of the shield on pl. XXIII.

One of the most interesting specimens is reproduced in $\mathrm{pl}$. XXVI, which is $147 / 8$ inches in diameter. This is the only shield of the series bearing a figure. It had four pointers, which suggest a sun disc, but the symbol seems clearly to be a conventional cross-section of a conch-shell; the well-known and often delineated symbol of Ehecatl, god of the air, one of the various attributes of the god Quetzalcoatl. In this example the light 




HEAD WITH HEAD-PIECE OF WOOD WITH MOSAIC DECORATION NATIONAL MUSEUM, COPENHAGEN 



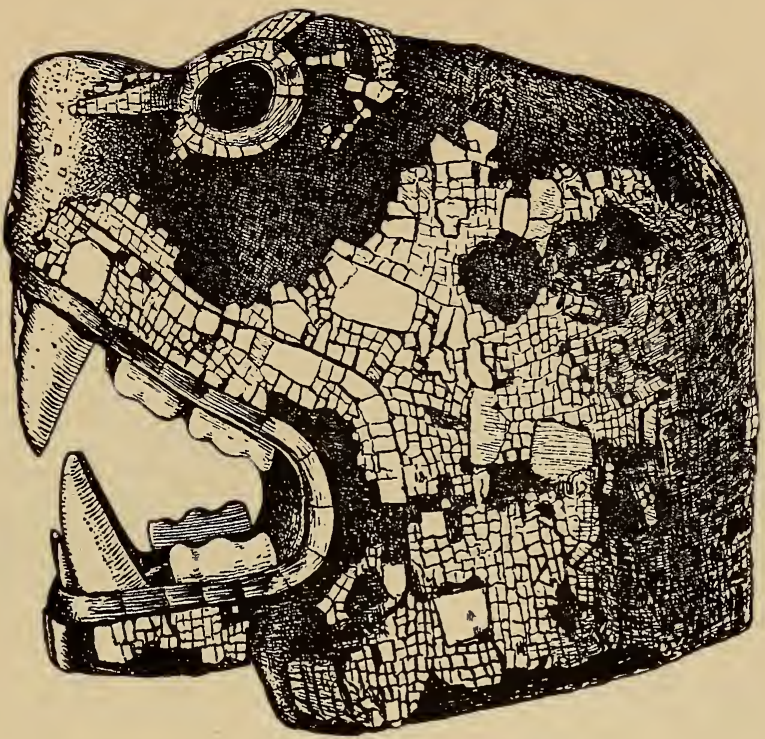

A

JAGUAR HEAD OF WOOD WITH MOSAIC DECORATION ETHNOGRAPHICAL MUSEUM, BERLIN

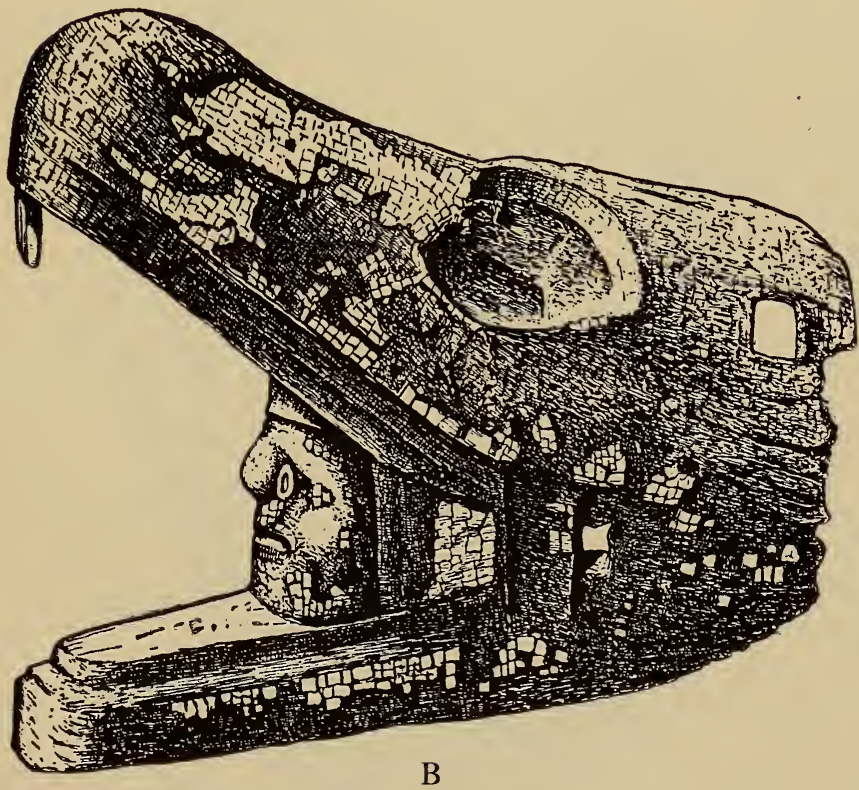

ANIMAL HEAD OF WOOD WITH HUMAN FACE IN OPEN JAW WITH MOSAIC DECORATION 



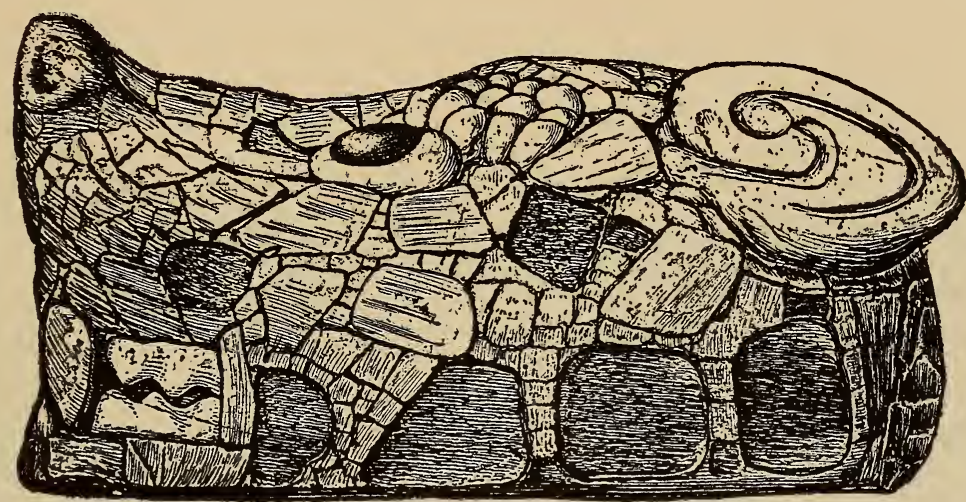

A

ANIMAL HEAD OF WOOD WITH MOSAIC DECORATION

STATE NATURAL HISTORY MUSEUM, VIENNA

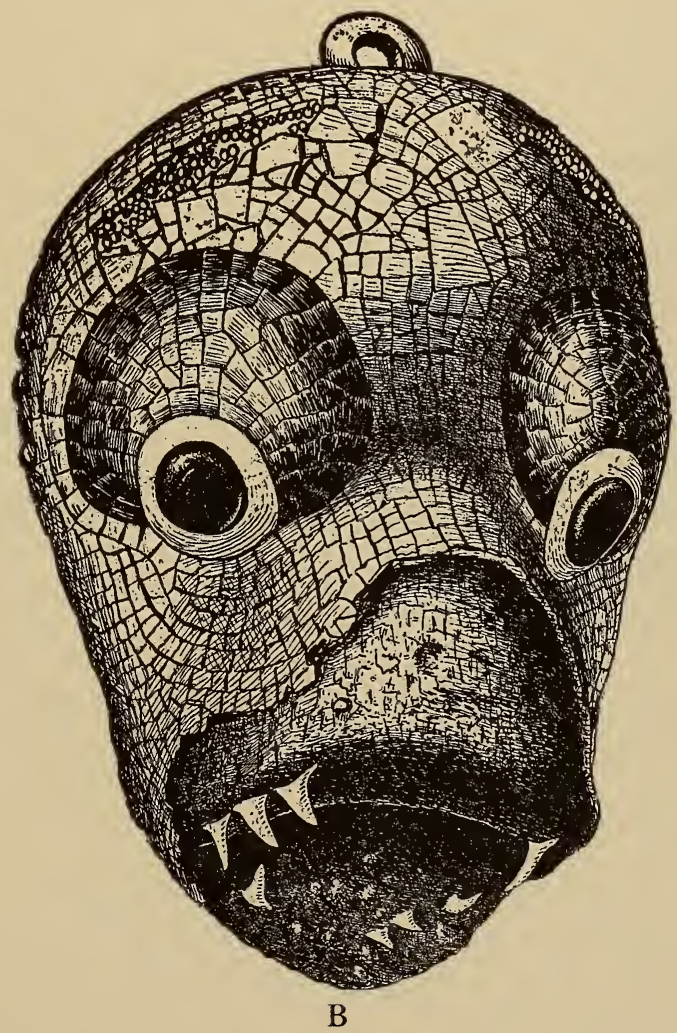

MONKEY HEAD OF WOOD WITH MOSAIC DECORATION 



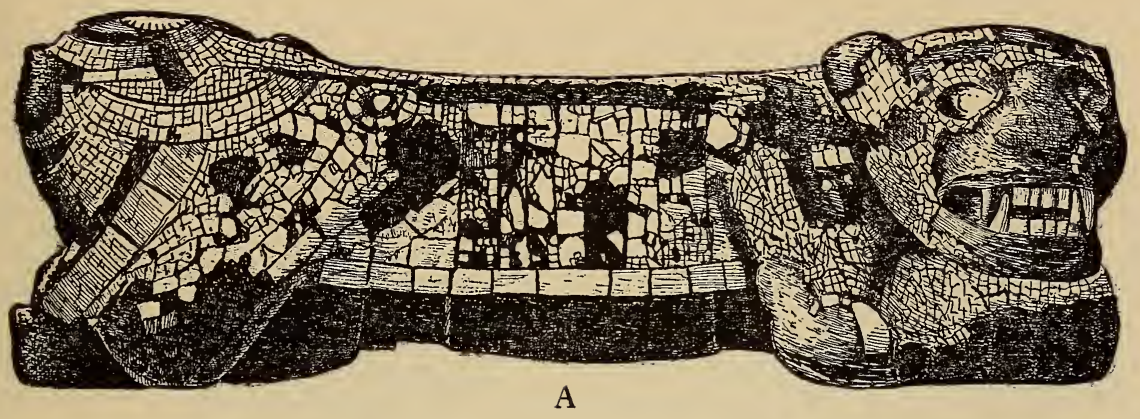

TWO-HEADED JAGUAR FIGURE OF WOOD WITH MOSAIC DECORATION ETHNOGRAPHICAL MUSEUM, BERLIN

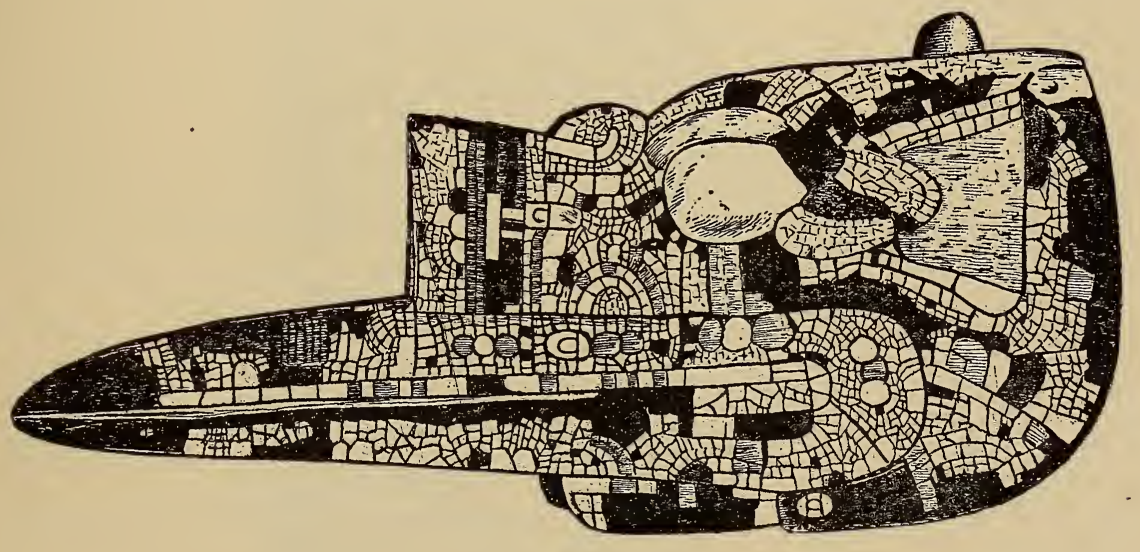

B

BIRD HEAD OF WOOD WITH MOSAIC DECORATION

MUSEUM, GOTHA 



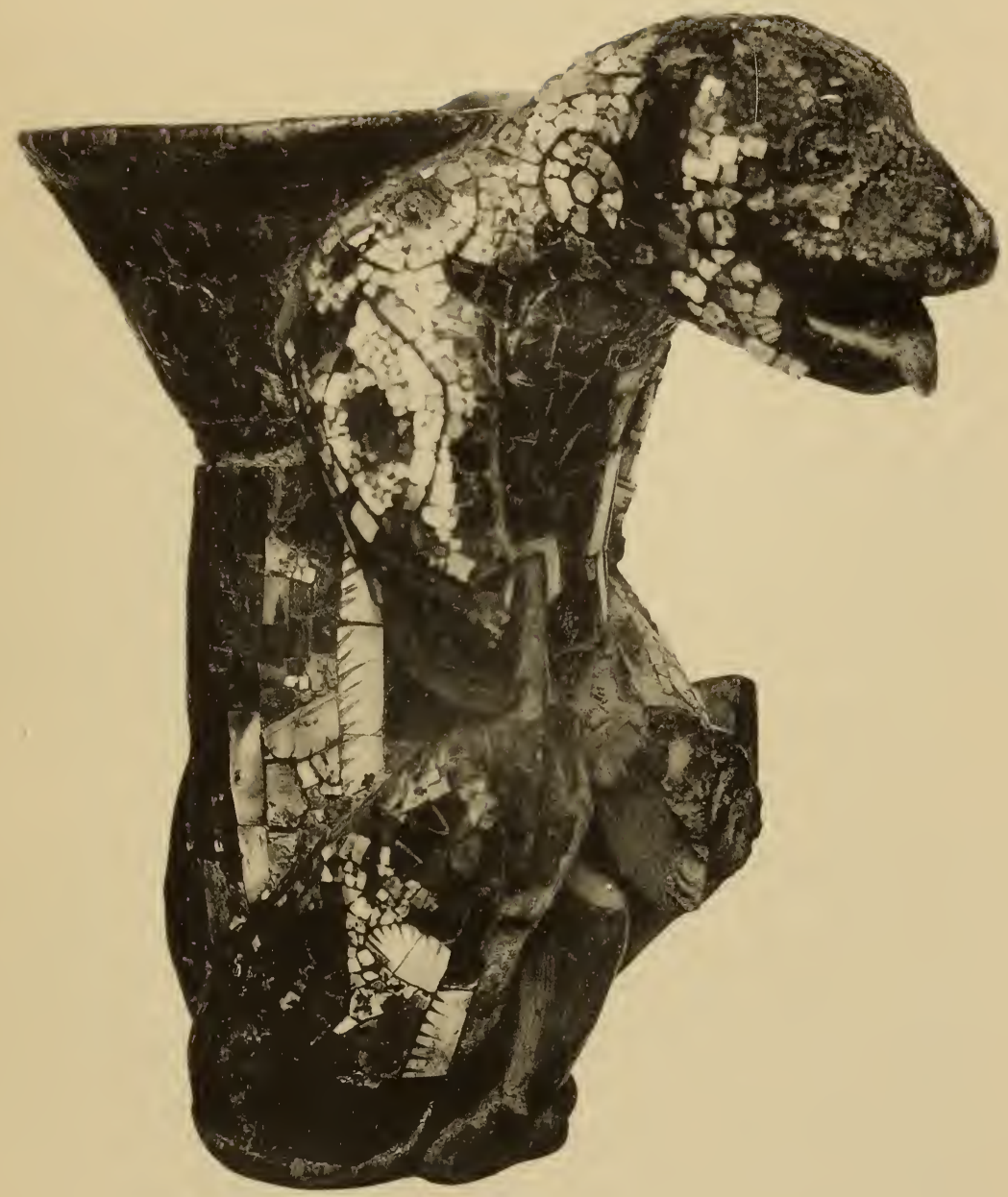

ANIMAL FIGURE OF WOOD WITH MOSAIC DECORATION BRITISH MUSEUM, LONDON 
pieces of stone are larger than in any other piece, but they are cut exceedingly thin. Around the outer edge of the mosaic is a faint incised line, and three lines may be seen projecting from the pointers, showing that the artist carried his guide-lines beyond the zone finally used. The circular line is so regular that there is no doubt that the workman used our methods, tying a piece of cord to an awl and working from the exact center of the shield.

The two fragments on pl. XXVII and XXviII are the same size - I5 inches in diameter. They are similar in workmanship; the special feature, the sprinkled outer band, has already been alluded to. In the first specimen an irregular cavity on the upper face was apparently filled in with cement, traces of which remain. The two holes in each shield are modern, but the two specimens came to us joined with leather strings. They are, however, sections of separate shields.

The last shield of the series (pl. XxIx) has a height of $145 / 8$ inches. It comprises little more than a third of the original object, hence the diameter must have been fully 15 inches or more. As in the others, we find the encircling bands, but as no part of the center remains, we do not know if it had a figure or was like the others of the series.

\section{Ear-plug}

With the deposit of masks and shields in the cave in the Mixteca, now in the Museum of the American Indian, Heye Foundation, was the unique wooden object shown on pl. $\mathrm{xxx}$. It is spool-shaped, the bottom flat, the upper part concave and covered with a mosaic of dark-green turquois, with a central disc of dark rose-colored shell. It is $1 \mathrm{I} / 2$ inch high, with a diameter of $13 / 4$ inch at the upper and lower rims. There is no doubt that this specimen was an ear-plug. The sides of the spool show the small gouges of the cutting instrument with which it was fashioned, and the entire surface not covered with mosaic was painted rose-red. 


\section{Animal Figures}

The specimen in the National Museum in Copenhagen, shown on pl. XxxI, has been described in detail by Lehmann, ${ }^{101}$ and our illustration is taken from his photograph. It is considerably damaged, much of the mosaic incrustation having disappeared. The materials are turquois, malachite, shell, and mother-of-pearl. In its original state it was one of the imposing pieces of this art. The upper projecting part rising from the top of the head probably simulated a plumed head-dress. Its extreme height is about $10 \mathrm{1} / 2$ inches, and the diameter only $33 / 4$ inches.

On pl. XxxII are illustrated two animal heads. The first $(a)$, a jaguar head, in the Ethnographical Museum in Berlin, has been described in detail by Lehmann in his paper published in the Proceedings of the Fifteenth Congress of Americanists, held at Quebec in 1906. It is $53 / 4$ inches high, and the mosaic is composed of turquois, malachite, and shell. The other specimen (b) is in the National Museum at Copenhagen. ${ }^{102}$ It seems to represent a serpent's head with a human face in the open jaws. The mosaic is turquois, malachite, and reddish shell. It has an extreme length of $131 / 2$ inches and is $81 / 4$ inches high. Much of the incrustation has fallen off.

The animal head shown on pl. XxxIII, $a$, is in the Vienna Museum, and has been illustrated by Heger in three views. ${ }^{103}$ Our drawing is the side-view, after Heger. This object is $45 / 8$ inches long from front to back. Much of the mosaic has fallen away, and the pieces of jadeite, obsidian, and shell are larger and the work is generally coarser than in any of the other examples in Europe. Heger's photographs depict a leather thong issuing from a hole at the back of the head.

The other mosaic on this plate $(b)$ is in the British Museum. It represents a monkey-like head of white wood, with open mouth. The mosaic coating is of turquois, malachite, and other stones. The back has a hemispherical depression coated round the sides with a thick layer of brown gum, smoothly finished, containing some woolen threads. The turquoises are 


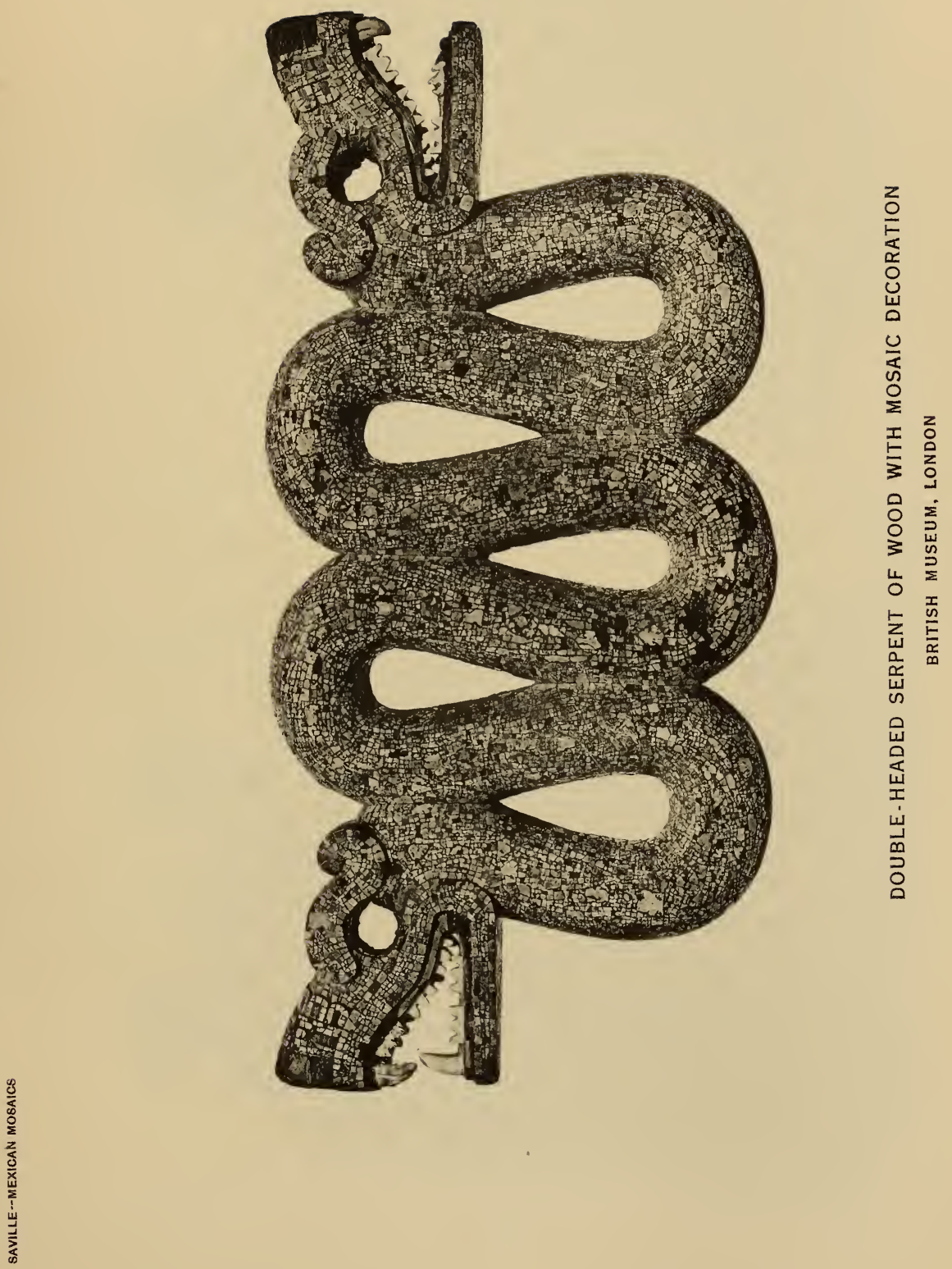




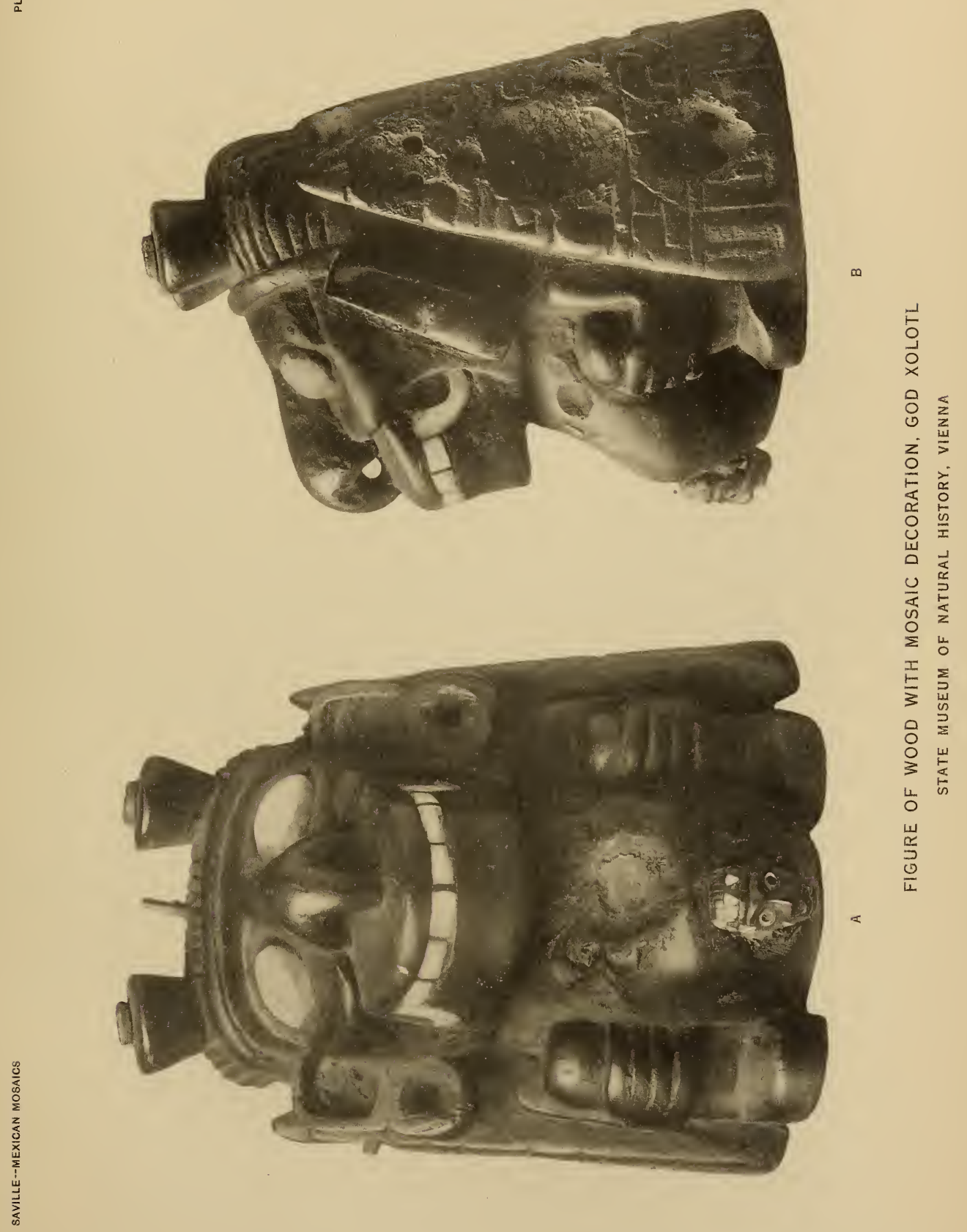

chiefly of the pale-greenish variety, but above the sides of the mouth are two patches of bright-blue stones. Each eye is set in the lower edge of a protuberance coated with malachite, the eyes themselves being convex discs of highly polished iron pyrites set in a ring of shell. Height 4 inches, width 2.7 inches.

An interesting piece is the two-headed jaguar figure in the Ethnographical Museum in Berlin (pl. XxxIv, a). ${ }^{104}$ It is covered with bits of turquois and malachite, together with some obsidian, shell, and mother-of-pearl. The eyes are of malachite. This specimen measures $125 / 8$ inches in length, and the workmanship seems to be very artistic.

An important and unique example of mosaic art is shown on pl. $\mathrm{xxxIV}, b$, which represents a bird's head embellished with an incrustation of turquois, malachite, obsidian, mother-of-pearl, red coral, and white shell, but much of the mosaic has fallen out. This specimen is in the Museum in Gotha. ${ }^{105}$

A much injured specimen in the British Museum is illustrated on pl. $\mathrm{xxxV}$, which represents an animal on his haunches, with open mouth and protruding tongue. On its back is a circular, cup-like receptacle. It is cut from a hard, pale-brown wood. Almost the entire surface was originally covered with mosaic laid in a bed of black gum, the component pieces being turquois, malachite, pink shell, pearl shell, and fragments of iron pyrites. The cup-shaped receptacle on the back of the animal is now covered with a transparent varnish, except in one place where the black gum and bits of mosaic are still in place. The varnish shows here and there fragments of gold-leaf, perhaps indicating that the cup was once entirely gilded. The height is 6.8 inches. ${ }^{106}$

The gracefully modeled breast-ornament representing a twoheaded serpent (pl. xxxvi) is in the British Museum. The base is of light-colored wood, hollowed at the back and painted red. The front of the snake is covered with turquois mosaic; the teeth and fangs in each open jaw of the snake are made of white shell, while the edges of the gums are indicated with pink shell. Across each nose is a raised band of turquois and 
red shell. The heads have mosaic-work on both sides, and it is probable that the eye-sockets formerly contained discs of iron pyrites. On the upper edges of the two loops of the bodies are holes for suspension. Length $17 \mathrm{I} / 8$ inches, height 8 inches.

\section{God Figure}

The figure of the deity shown in pl. XxxvII is in the Vienna Museum. It has been described by Dr. Heger, who has kindly sent me a number of photographs of the object, and some details regarding it. This has been identified by Dr. Seler as representing the god Xolotl, one of the deities or guardians of the Tonalamatl. ${ }^{107}$ The specimen does not contain much mosaic decoration, being of highly polished wood. It is $3 \frac{1}{2}$ inches high and $23 / 4$ inches broad. Dr. Heger has courteously sent me the following notes concerning the specimen:

The posterior circular cavity (see side view) is partly filled with a resin-like mass, by means of which the piece must have been fastened to some other object. Vestiges of this resin-like substance are found in all the hollowed places where today some of the inlay is missing, as in each of the three rounded oval incurvations, of both lateral walls, in which probably small heads [of mosaic?] were also incrusted.

The eyes and the six small teeth consist of milk-white shells; the two hook-like canines consist of white mother-of-pearl-like shells. The two large ear-lobes, as well as the inferior part of the nasal septum, are perforated transversely. The pretty little human head at the navel of the figure probably consists of pitch-black obsidian. The ear-pendants are missing on the left side. The pupils of the eye (right one missing) are enclosed in small rings of mother-ofpearl. Projecting from the opened mouth, there is above the red tongue another small white shell-plate with three sharp downward points (teeth). The little head shows injury in several places.

\section{Knife Handles}

The next group of objects to be noted consists of knife handles. The beautiful specimen on pl. xxxvin is in the British 








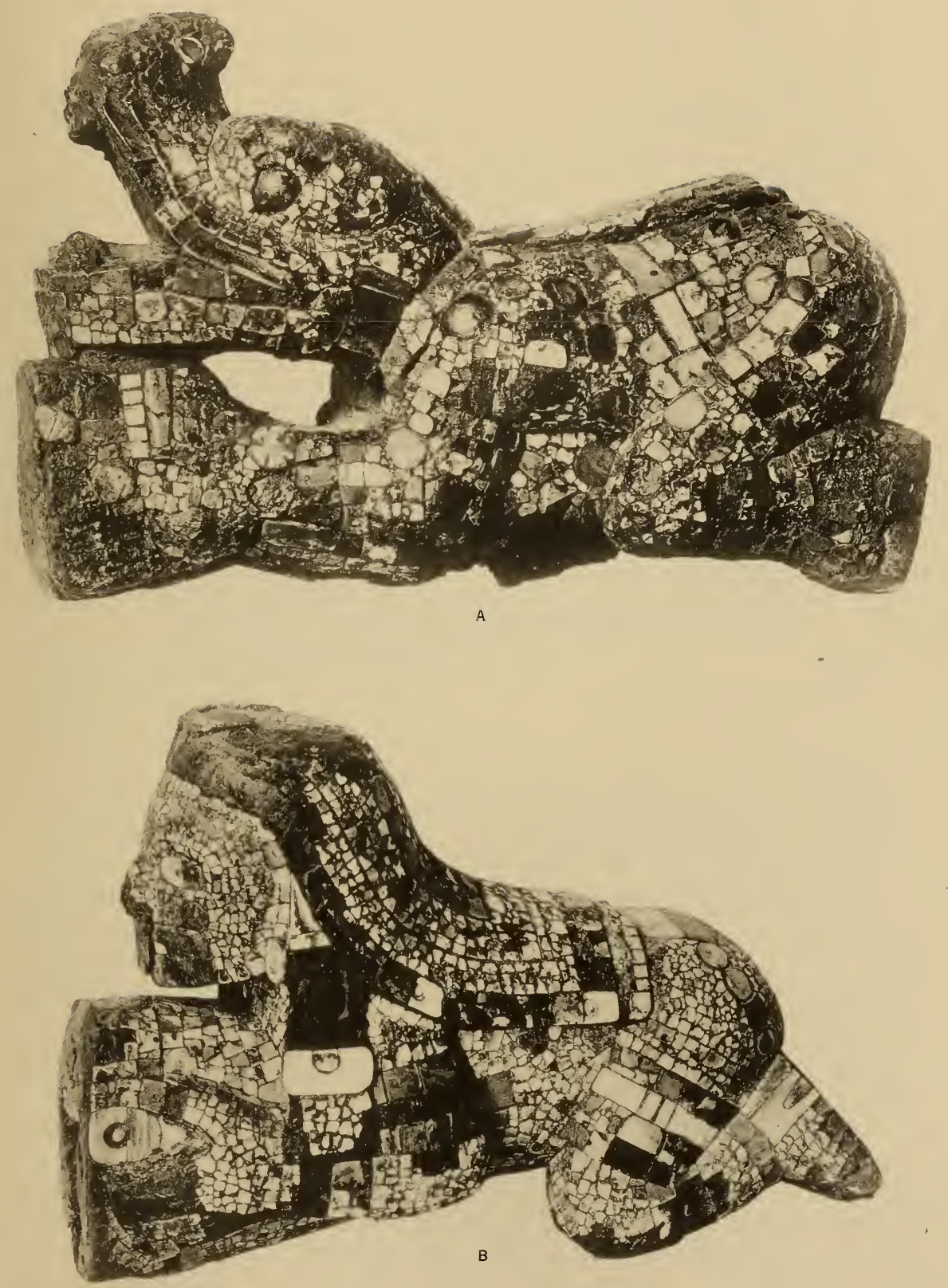

KNIFE HANDLES OF WOOD WITH MOSAIC DECORATION PREHISTORIC AND ETHNOGRAPHIC MUSEUM, ROME 

Museum. It is a chipped leaf-shape bladed knife of honeycolored chalcedony. The handle is of a soft, light-colored wood, carved in the form of a crouching human figure. The actual socket in which the blade is fixed proceeds from the chest of the figure, which grasps it with a hand on each side, and rests his chin on the top. The socket is firmly bound with cord. The figure and the socket up to the binding have been covered with

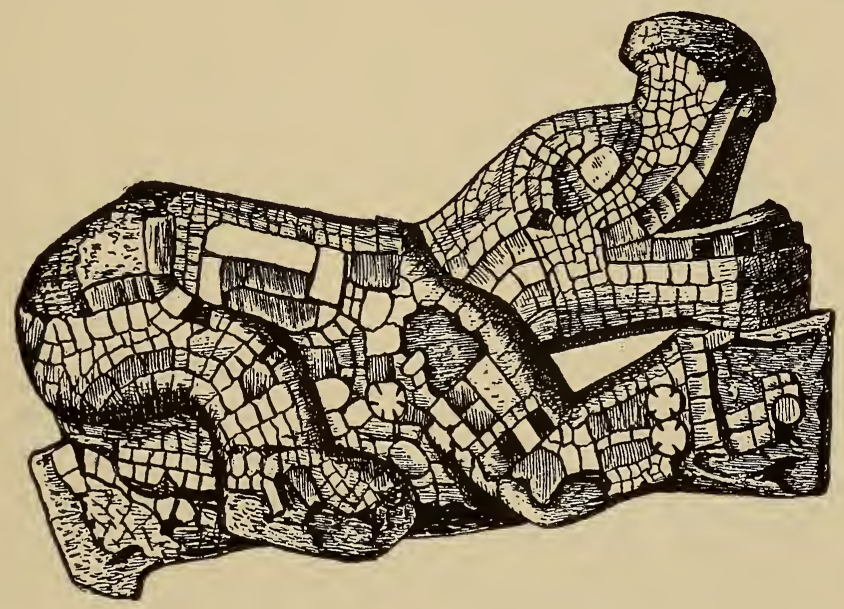

FIG. 19

a mosaic, chiefly of turquois, varied with malachite and white, pink, purple, and orange shell, as well as a few pieces of pearl shell. Much of the mosaic has disappeared. The figure wears an eagle mask, the face appearing in the open jaws. This knife, which measures $121 / 2$ inches in length, is one of the most artistic of mosaic specimens.

Belonging to this class are the two handles on pl. xxxIx, which are in the Museum in Rome. They have been illustrated in colors by Pigorini. Through the interest of Dr. Lothrop we are enabled to present photographs of these two very interesting objects, together with some additional observations concerning them. The first piece (pl. XxxIx, $a$, and fig. I9 after Pigorini), is in the form of a crouching figure with 
an animal head and wide-open mouth. It has been described as a knife handle, like the other specimen $(b)$, which is unquestionably of that character, but Dr. Lothrop writes that the front of this piece $(a)$, where the knife blade should be inserted, is smoothly covered with a kind of cement, while in the belly of the figure is a large hole. From Dr. Lothrop's examination of the specimen he was unable to satisfy himself whether it was a knife handle or was intended to be placed on the head of a staff. The materials used for the incrustation are turquois, reddish shell, dull white shell, mother-of-pearl, and small flakes of gold. In the Pigorini illustration, which represents the side opposite that shown here, two flakes of gold are shown, one in the eye, the other on the arm between elbow and shoulder.

The other piece (pl. $\mathrm{xxxIx}, b$ ), unquestionably a knife handle, as stated, of the same technique as the specimens in the British Museum, represents a crouching human figure. The materials are turquois, dark-green malachite, white shell, mother-of-pearl, and red shell. Lothrop calls our attention to the tiny pieces of turquois set in shell on the shoulder and in other places. He also states that a portion of a broken chert (?) blade is still imbedded in the socket in front of the figure.

\section{Human Femur Musical Instrument}

The last of the specimens of mosaic to be described is the musical instrument (omichicauaztli) made from a left human femur, illustrated on pl. XL. This unique example, which is in the Museum in Rome, has been reproduced in colors by Pigorini. The mosaic seems to have been confined to the head and neck, although the trochanter major may also have been covered at one time. The incrustation at present consists of gum in which are pinkish-orange bits of colored shell. A modern copper chain is attached to the bone, from which hangs an oliva shell, undoubtedly ancient.

According to Dr. Lothrop, the oliva shell shows signs of wear, and was probably the instrument used for rasping the 


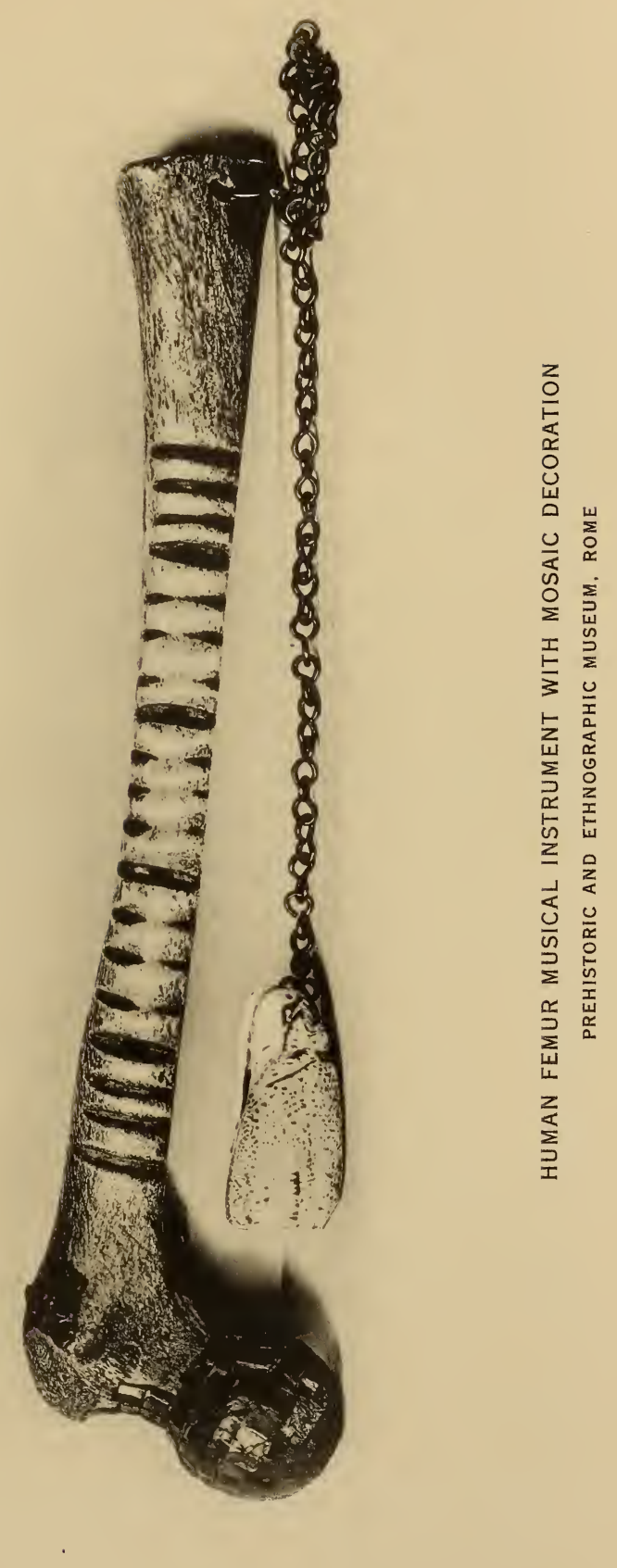



bone, as the bone is sound and produces a rather musical tone when scraped with the shell, as if the bone were of china.

Notched human bones are not uncommon in ancient Mexico, and some have been found elaborately engraved. In the course of excavations made in 1900 in the street back of the Cathedral in the City of Mexico, were uncovered many small pottery models of musical instruments which had been placed there undoubtedly when the foundations of the great Aztecan teocalli were laid. The writer secured for the American Museum of Natural History examples of these interesting models. Among them was a notched bone having attached to it a model of the handled instrument with which it was rubbed or rasped. ${ }^{108}$

Finally, attention is called to three objects of wood, of Mexican origin, in the Museo Borgiano, Rome. They have been described by Colini, and two of the pieces illustrated, in the Bollettino della Societa Geografica Italiana. ${ }^{109}$ The first is an idol representing a human figure, $173 / 4$ inches in height; the other two specimens, those figured by Colini, are masks, and it is highly probable that all of these pieces were once decorated, at least in part, with mosaic. One of the masks is $67 / 8$ inches, and the other $71 / 8$ inches, in height. 


\section{CONCLUSION}

IN view of the considerable number of objects of stone mosaic that were sent to Europe during the first years of the Spanish conquest of Mexico, part of the loot obtained by Hernán Cortés, it is quite possible that other examples are still hidden away either in Spain or in Italy, which some day will be brought to light. Only twenty years ago two wonderfully preserved carved ceremonial spear-throwers, or atlatls, of wood, covered with delicate gold-leaf, were found in an old leather-covered case in a house in Florence, and are now exhibited in the Ethnological Museum of that city. It is not to be doubted that they were sent from Mexico by Cortés himself, and remained stored away, unknown to the world, until recent times. Bushnell, who figured and described these atlatls, believes that they were formerly in the famous collection of the Medicis, and that other objects of Mexican origin may be hidden away in Italy, to be revealed from time to time. ${ }^{110}$ Again, in I89I, Mrs. Zelia Nuttall was the first to bring to our notice the important mosaic shield, and the still more interesting feather-mosaic shield in the Castle Ambras near Innsbruck, which were shortly afterward transferred to the ethnographical section of the State Natural History Museum in Vienna. ${ }^{111}$

We should call attention here to the possibilities of finding mosaics in Mexico, emphasizing the fact that the collection in the Museum of the American Indian, Heye Foundation, was found under archeological conditions. Until now we have been somewhat sceptical in regard to the possibility of wooden objects of such a fragile and perishable nature being discovered either in tombs or in ruined buildings in Middle America. As we have already written, the few traces of this mosaic art found heretofore in excavations have been of a fragmentary character. No specimens of wood covered with mosaic have been found previously in Mexico, with the exception of the 
small rim of wood excavated by Gamio in Zacatecas, and the four pieces from Chichen Itza. In the tropical and temperate zones, where the most important ancient sites are situated, artifacts of wood of any sort have rarely been unearthed. It is true that in some of the remote villages carved wooden drums (teponaztli) have been religiously guarded from the time of the conquest, and are brought out and played at certain festivals during the year. But these drums are kept in the cabildos, and are preserved with zealous care.

We would again call attention to the statement of Sahagun regarding the tradition of the abandonment of Tula, that Quetzalcoatl ordered certain precious things to be buried in the neighboring hills and ravines. This, of course, refers to times long anterior to the coming of white men. After this unfortunate event, fatal indeed to the Indian, the natives undoubtedly secreted a vast amount of material. The circumstances concerning this have been told by Father Motolinia. As this account is but little known, we have translated literally the entire chapter, for it reveals to us the miserable state into which the aborigines had fallen within twenty years after their subjugation.

Of how there was an end of idols and of the feasts which the Indians were wont to prepare, and of the vanity and the endeavor which the Spaniards displayed in (their) search for idols.

The feasts which the Indians made, as is told in the first part (of this book), with their ceremonies and pomp, all ended from the beginning (of the time) that the Spaniards were making war (on them), because the Indians had so much to think about in their tribulations that they did not think of their gods, not even of themselves, because they had so much sorrow that in order to remedy that, all the principal (things in their lives) were stopped.

In every town they had an idol or demon whom they considered chiefly as their mediator, and called him such, and they honored and adorned him with jewels and garments, and the best they could find they offered him, each town as it was (able to), and more so in the capitals of provinces. These principal idols I mention, as soon as the city of Mexico was taken by the Spaniards, with their jewels and 
wealth the Indians hid in the most secret place they could find; a large part of the gold that was on (or with) the idols and in the temples they gave as tribute to the Spaniards under whose patronage they belonged; for they could not do otherwise because in the beginning the tributes were so excessive that all the Indians could scrape together or search for, nor what the lords and chiefs had, would suffice; besides, they were forced (to pay tributes) with such iniquity that they also gave the gold they had in the temples of the demons (idols), and even when this was exhausted they paid tribute in slaves, and many times not having slaves in order to comply (with the taxes), they gave free (Indians) as slaves.

These principal idols, with the insignia and ornaments or garments belonging to the demons, the Indians hid, some in the earth, others in caves, and still others in the woods. Later, when the Indians became converted and were baptized, they unearthed many (of them), and they brought them to the courtyards of the churches to burn them publicly. Others rotted in the earth, because after the Indians had received (or accepted) the Faith, they were ashamed to take out those they had hidden, and would rather let them rot than that anyone should know that they hid them. And when they were importuned to tell (talk) about their principal idols and their vestments, they took them out, all decayed, of which I am a witness, for I have seen it (done) many times. The excuse they gave was good, for they said, "When we hid it, we did not know God, and we thought the Spaniards would soon return to their (own) country, and after we came to understand (about) God, we left it to rot, because we were afraid and ashamed to take it out." In other towns these principal idols with their vestments were in the care of the lords or of the principal priests of the demons, and those kept them so secretly that hardly anyone knew about them except two or three people who guarded them, and of these (idols) they also brought a very large number to the monasteries to burn them. In many other remote villages, far away from Mexico, when the monks went there to preach, they told them in their sermons and before christening them that the first thing they had to do was to bring all the idols they had and all the insignias of the demons to burn (them): and in this manner they also gave and brought a large quantity which was publicly done in many parts (of the country): because wherever the doctrine and the word of God has reached, not a thing has remained 
that they knew or could tell about, for if from now on for a hundred years they should dig in the courts of the temples of the ancient idols, they would always find idols, because there were so many that they had made: for it happened that when a child was born they made an idol, and the following year (they made) one a little larger, and after four years they made another one, and as the child grew up they went on making idols, and of these (idols) the foundations and walls are filled, and in the courts there are many of them. In the year (I5) 39 and in the year (I5)40 several Spaniards, some with authority and some without it, to show their zeal of the Faith, and thinking that they were accomplishing something (worth while), began to dig and to unearth the dead and to urge the Indians that they should give them idols: and in some parts (of the country) this reached such a stage that the Indians went to look for the idols that were decayed and forgotten in the earth, and some of the Indians were even so sorely tormented that, to tell the truth, they made new idols and gave them (to the Spaniards) that they should cease maltreating them.

Mixed with the great zeal they (the Spaniards) showed in searching for idols, (there was) not a little covetousness, and it was because the Spaniards (would say), in such a village, or in such a parish, there are (were) idols of gold, or of chalchihuitl which is a stone of great value, and they imagined that there was an idol weighing ten or fifteen arrobas: but in truth they came (too) late, because all the gold and precious stones were spent and cashed in and safely in the power (hands) of the Spaniards who first held those Indians under their jurisdiction. They also thought of finding an idol of stone which would be worth as much as a city, and certainly, although I have seen many idols which were adored and held highly by the Indians and (were) very (greatly) revered as chief gods, and some were of chalchihuitl, the one which seemed to me to be worth most, I do not think that in Spain they would give ten pesos of gold for it: for this they upset and stir and scandalize the towns with their truly indiscrete zeal, because if there really is still an idol in some village, it is either rotten or so (completely) forgotten or (held or kept) so secretly that in a town of ten thousand inhabitants there are not even five who know it, and they hold them for what they are, either for stones or for wood. Those who thus upset these Indians who go their straight way, are like Laban who went to meet Jacob to look for his property, and to upset his house in search of his idols, 
because of this that I am telling here I have great experience and I (can) see the deceit in which they go about and the way they have to disturb and disfavor (hurt) these poor Indians who have forgotten so absolutely their idols, as if it were a hundred years ago (that they had had them). ${ }^{112}$

Hernándo Ruiz de Alarcon, in his treatise on the superstitions of the natives of New Spain, relates that when they went to the hills or other remote places where their idols were hidden away, or to certain piles of stones where they often made offerings and sacrifices, they carried there offerings which were sometimes copal incense wrapped in quauhamatl, a kind of white paper made from the bark of a soft tree. This work, written in 1620, is entitled, Tratado de las Supersticiones y Costumbres Gentilicas que oy viuen entre los Indios Naturales desta Nueva España, and was published for the first time in 1892 by the Museo Nacional of Mexico. The present writer has noted such stone piles, particularly in Yucatan.

It is probable that we have here an explanation of the existence of our deposit of mosaic-incrusted wooden shields and masks, which leads us to hope that still further discoveries of this character may be made. The climatic conditions in certain parts of the highlands of Middle America, where this deposit was found in a cave, favor this assumption. There are great sections of comparatively dry, wind-swept, almost desert plains, treeless hill-slopes, and ravines, where the chief vegetation is cacti in the lower altitudes, while higher up pines and oaks abound. Here wooden objects should be indefinitely preserved in ancient tombs or in caves, protected by a covering of loose, dry earth, the condition under which our collection was found.

The discovery of this remarkable collection of mosaics emphasizes the fact that the investigation of the archeology of Mexico is hardly commenced, in view of the vast amount of material hidden under the ruins of thousands of ancient settlements and burial places, and probably in countless caves, which still remain untouched by the archeologist. 
As revealed by the surprising results of Thompson's dredging in the sacred cenote in Yucatan, a wealth of archeological material also lies buried in the mud under the waters of sacred wells and lakes. This is notably so in the case of Lake Chapala, on the borders of Michoacan and Jalisco in Mexico, ${ }^{113}$ and of Lake Amatitlan in Guatemala, where thousands of pottery vessels and other objects have been recovered from the bottoms of the lakes by divers, and from the mud when the waters have receded from the shores during times of extreme drought. These objects had been thrown into the waters as offerings to the gods.

The recent results of the systematic exploration of the great mounds at Teotihuacan have been quite surprising, and have shed new light on the archeology of the central plateau of Mexico. Even more important is the discovery of culture sequences in stratified deposits in the valley of Mexico, the investigations showing three distinct culture layers distinguished by the character of the pottery. Of great significance are the discoveries recently made under the great lava flow called the Pedregal, at the very edge of the City of Mexico, where the artifacts correspond in toto with those found in the bottom layer of the stratified deposits. ${ }^{114}$ These discoveries mark a great advance in our knowledge of the history of ancient Mexico, but, as we have before stated, they are only a beginning. Buried underground are the "books" the student must study, if ever the tangled history of Middle America is to become known and the story of the development of this exceedingly interesting division of the human race is to be recorded. 


\section{NOTES}

I. See Saville, The Goldsmith's Art in Ancient Mexico, Museum of the American Indian, Heye Foundation, Indian Notes and Monographs, 1920.

2. Gonzalo Fernández de Oviedo y Valdés, Historia General y Natural de las Indias, edition of the Real Academia de la Historia, tomo I, primera parte, lib. XVII, caps. VIII-XVIII, pp. 502-537, Madrid, I85I.

3. The Itinerary of Grijalva, written by chaplain Juan Díaz, was undoubtedly recorded in Spanish, but we know it only from the Italian translation of 1520. It was translated into Spanish by Joaquin García Icazbalceta and published by him in his Documentos para la Historia de México, tomo I, Mexico, 1858. A translation into English, with translations of other accounts, relating to this voyage, will appear in the Publications of the Cortes Society under the title, The Voyage of Juan de Grijalva to Yucatan and the Mexican Coast in 1518.

4. We quote here from the edition of Bernal Díaz published by the Hakluyt Society, bearing the title, The True Conquest of New Spain, translated into English by Alfred Percival Maudslay. The citation is from vol. I, pp. 48-49, London, 1908.

5. Bernal Díaz, op. cit., vol. I, p. 53. In the work of Torquemada, Monarchia Indiana, is an important statement bearing on this matter, of which we give the following translation in extenso:

"And this present it was that Gomara and Antonio de Herrera make confused mention as having been brought to Ferdinand Cortés by the governors of Montezuma on his first landing, which they notice in the following words: 'Which present it is said was sent for Juan de Grijalva, when he touched on those shores; but that, notwithstanding the haste of those who carried it, they found that he was gone.' The fact was as they state; but I do not understand how those who drew up the account of which Herrera availed himself, could have omitted that which I say in this chapter, and many other particulars which shall be observed in the sequel; since the circumstances which they mention, and those which I relate, are intimately connected with each other, and those who could have given an account of the former, could likewise have done so of the latter; although I think that the error lay in their seeking information only from the Spaniards, who at that period returned from the Indies, without verifying facts by applying to the Indians, who were mainly concerned in most of them, or I may say in all, since they were the mark which all who have written on the affairs of the conquest strove to hit, and were those who were very well acquainted with them, and in the beginning recorded them by means of figures and characters, and afterward, when some of the most curious 
amongst them had learned how to write, wrote them down; which histories are in my possession: and so high is the estimation in which I hold them, on account of their language and the style of their composition, that I should be glad to feel myself competent to the task of translating them into Spanish with the same elegance and grace as the Mexicans penned them in their own language; and since these histories are true and authentic, I follow them to the letter; but lest the accounts which they contain should appear strange to those who read them, I affirm that they are merely a true relation of what actually happened, but that other authors have not noticed them before me, because the few that have written on the affairs of the Indies were ignorant of the events which then occurred, nor had they any one to give them the requisite information; neither should I have mentioned these facts had I not found that they were verified by Father Bernardino de Sahagun, a grave and pious ecclesiastic, who was of the second number of those who undertook the conversion of the natives of New Spain, but was the first of the investigators of the most secret things of this land, of which he knew all the secrets, and employed himself for more than sixty years in composing works in the Mexican language and in incorporating into it all the information which he was able to acquire." Lib. IV, cap. XIII.

6. This important work will be reprinted in facsimile, with a translation into English, in the author's proposed work on the voyage of Grijalva, as mentioned in Note 3.

7. This account will also be reprinted in facsimile, with a translation into English, in the author's account of the voyage of Grijalva. The title is, Provinciæ Sive Regiones in India Occidentali Noviter Repertæ in Vltima Navigatione. The known copies are in the John Carter Brown Library, Providence, and the New York Public Library.

8. I quote here from the translation made and edited by Francis A. MacNutt, De Orbe Novo, vol. II, pp. I9-20, New York, 1912.

9. The chapters relating to the voyage of Grijalva have been translated into English by the writer and will appear in the proposed work mentioned in Note 3 .

I0. Francisco López de Gomara, edition of Don Enrique de Vedia, Historiadores Primitivos de Indias, in Biblioteca de Autores Españoles, tomo I, Madrid, 1877.

I I. Eduard Seler, Ein Kapitel aus dem Geschichtswerk des P. Sahagun, p. 124, Berlin, 1890 .

12. Lehmann, in his Methods and Results in Mexican Research, Paris, I909, writes: "Hardly less remarkable are the mosaics made of more or less precious stones, shells, etc. No less than twenty-three pieces are known in various museums, the finest being in London, Rome, and Berlin. The stones when cut to shape are embedded in a peculiar substance (tzinacanquauhcuitlatl) covering the whole surface of the object to be decorated; the latter were 
chiefly of wood, rarely of bone or stone. Two masks are skilfully prepared human skulls. The usual shapes are shields, helmets, knife handles and trinkets. The small cup-shaped heads and the double-jaguar in the Berlin Museum are of doubtful meaning. Most of these objects apparently come from the Eastern provinces, i. e., Tabasco. We know from other sources that it was only under king Ahuizotl, with the conquest of the Tzapotec district, that the Mexicans became acquainted with turkois-mosaics, shields, earrings, etc." This is a translation of his Ergebnisse und Aufgaben der mexikanistischen Forschung, published in Archiv für Anthropologie, Neue Folge, band vi, heft 2 u 3, Braunschweig, 1907.

13. See Lehmann in our List of Works Describing Mexican Mosaics, under I906.

I4. Juan de Torquemada, Monarchia Indiana, Barcia edition, Madrid, I732, lib. II, cap. LXXIX, p. 2 I 5.

15. See Antonio Peñafiel, Nomenclatura Geográfica y Etimológica de México, Mexico, I 897 .

I6. Clavigero, The History of Mexico, Cullen transl., vol. II, p. 232, London, I 787 .

I7. Saville, The Goldsmith's Art in Ancient Mexico, op. cit.

I8. Peter Martyr, op. cit., vol. II, p. 46.

19. Las Casas, Historia de las Indias, tomo IV, cap. CXxI, pp. 284-286, Madrid ed., 1876.

20. Fr. Bernardino de Sahagun, Historia General de las Cosas de Nueva España, Bustamante ed., lib. I2, caps. II-VI, pp. 5-I2, Mexico, I829.

Notes to Chapter III. The two places mentioned here, Naulitlantoztlan and Mictlanquactle, are given by Torquemada (op. cit., lib. IV, cap. XIII, p. 379) as four different towns. Nauhtla and Toztla, the first two, are recognizable as being combined into one place-name by Sahagun. This is also the case with Mictla and Quauhtla, the third and fourth towns of Torquemada, the Mictlanquactle of Sahagun. Brasseur de Bourbourg transforms them to Nauhtlan, Tochtlan, and Mictlan-Quauhtla, in which he is followed by Orozco y Berra.

Vigil, the editor of Tezozomoc, states that the town of Mictlancuauhtla has disappeared, but in a map or plan of Vera Cruz in the collection of Icazbalceta, sent in 1580 to Philip II by the alcalde Alvaro Patiño, the place is still mentioned, under a corrupted form of the name, as Metlangutla.

The name of the five lords sent by Montezuma to receive Cortés, conceived to be Quetzalcoatl, are spelled differently by Torquemada (op. cit., p. 379), and they more closely approach the orthography of Molina's dictionary. They are, Yohualychan, Tepuztecatl, Tizahua, Huehuetecatl, and Hueycamecateca.

Notes to Chapter vi. This Xicalanco is not to be confused with the Mexican colonial town of the same name near the Laguna de Términos, 
Tabasco. A branch of the Nahuan Mexican people called Xicalancas from the name of their first ruler, Xicalancatl, settled on the coast of Vera Cruz in the region between the present city of Vera Cruz and the Isthmus of Tehuantepec.

Torquemada relates that the messengers, on leaving the ship of Cortés, "paddled rapidly away, and came to a little island called Xicalanco, where they ate, and rested a little, and they left there and came to a town on the seashore called Tecpantlayacac; from there they went to Cuetlaxtla, which is some leagues in the interior, where they spent the night; the lords and chief of the town begged them to remain there that day and rest, but they replied that the need for speed for their journey was great. "-Op. cit., lib. IV, cap. XIV, p. 384 .

21. Peter Martyr, op. cit., vol. II, pp. I96-I97.

22. Saville, Goldsmith's Art in Ancient Mexico, The inventories of the loot obtained by Cortés are given in English translation on pp. 56-102.

23. This is quoted from the study of Dr. J. Cheston Morris on the "Physical and Technographical Characteristics" of the leaves, in the article, "The Tribute Roll of Montezuma," edited by Dr. Daniel G. Brinton, Henry Phillips, Jr., and Dr. J. Cheston Morris, published in Transactions of the American Philosophical Society, vol. xvir, N. s., pt. II, art. IV, p. 6I, Philadelphia, I892.

24. The very important Crónica Mexicana, written by Hernando Alvarado Tezozomoc, was published by José M. Vigil in his Biblioteca Mexicana, Colección Metódica de Obras y Documentos Relativos a la Historia, Geografía, Literatura, Estadística y Legislación de México, $188 \mathrm{I}_{\varepsilon}$ The quotation is from cap. Lxxvi, pp. 543-544.

25. Tezozomoc, op. cit., cap. Lxxxix, p. 600.

26. Dr. George F. Kunz has kindly placed in our hands his publications relating to precious stones. In this connection consult his Gems and Precious Stones, New York, I892; his important paper, New Observations on the Occurrences of Precious Stones of Archæological Interest in America (extrait des Mémoires et Déliberations du XV $\mathrm{V}^{e}$ Congrès des Américanistes tenue à Québec du ro au 15 Septembre 1906, Quebec, 1907); and Gems and Precious Stones of Mexico, Mexico, I907.

27. The work of Rafael Aguilar y Santillan is entitled Bibliografía Geológica y Minera de la República Mexicana completada hasta el año de I904, Boletín del Instituto Geológico de México, núm. I7, Mexico, I908.

28. The interesting study of Luigi Pigorini describing the Mexican mosaics in Rome is entitled Gli Antichi Oggetti Messicani Incrostati di Mosaico esistenti nel Museo Preistorico ed Etnografico di Roma, Reale Accademia dei Lincei, Rome, Anno CCLXXXII, I $884-85,3^{\text {a }}$ serie, vol. XII, pp. I-9, I pl. with 5 colored illustrations.

29. The important study by Joseph E. Pogue, The Turquois. A Study of its History, Mineralogy, Geology, Ethnology, Archæology, Mythology, Folk- 
lore, and Technology, appears as the third memoir of Vol. xII, Memoirs of the National Academy of Sciences, Washington, 1915.

30. Fray Bernardino de Sahagun, Historia General de las Cosas de Nueva Espa ña que en Doce Libros y Dos Volúmenes Escribió el R. P. Fr. Bernardino de Sahagun, published by Carlos María de Bustamante, 4 vols., Mexico, I829. Also published by Lord Kingsborough. The quotations are from the Bustamante edition, tomo III, lib. I I, cap. vII, p. 284, and cap. viII, pp. 296-297.

3I. On this subject consult the paper by Dr. A. B. Meyer, Die Nephritfrage, ein ethnologisches Problem, Berlin, 1883, of which an abstract ("The Nephrite Question") was published in American Anthropologist, o. S., vol. r, no. 3, Washington, July, 1888.

32. Saville, A Votive Adze of Jadeite from Mexico, Monumental Records, New York, May, I90o.

33. Sahagun, op. cit., tomo III, lib. I0, cap. xxIx, p. I07.

34. Ibid., cap. vii, p. 19.

35. The pictorial part of the section of the great work of Sahagun in Florence was reproduced in facsimile by the late Mexican scholar, Sr. D. Francisco del Paso y Troncoso, for the Mexican government. Only recently has the work been received in Mexico, and we are under the greatest obligations to Sr. D. Luis Castillo Ledon, Director of the Museo Nacional, Mexico, for a copy which we have recently received, and which has been of such great assistance in the preparation of this study of Mexican mosaics. It is an Atlas, denominated Vol. V, of ${ }^{5} 8$ estampas (plates). The plates relating to arts and crafts are to illustrate Libro Ix, and include pl. Iv to lxxvi.

36. We refer the student to the edition of Lord Kingsborough, vol. I.

37. The Mappe Tlotzin once formed a part of the Boturini collection; it was afterward acquired by Aubin, later by Goupil, and is now in the National Library in Paris. It has been published in colors (pl. i-iii) in Mémoires sur la Peinture Didactique et l'Écriture Figurative des Anciens Méxicains, par J. M. A. Aubin, with an introduction by E. T. Hamy, Paris, 1885. The pictures referred to are on pl. ii.

38. Eduard Seler, L'Orfèverie des Anciens Méxicains et leur Art de Travailler la Pierre et de Faire des Ornements en Plumes, Compte rendu de la VIII İme Session $d u$ Congrès International des Américanistes, Paris, pp. 40I-452. The chapter on the art of the lapidaries is on pp. 418-425. The article, with slight changes in the French translation of the Nahuatl text, and some revision, is included in Seler's Gesammelte Abhandlungen zur Amerikanischen Sprach- und Alterthumskunde, Zweiter Band, pp. 620663, Berlin, 1904. The section on the lapidaries' art is on pp. 635-640.

39. Sahagun, op. cit., tomo II, lib. 9, cap. XVII, pp. 389-39I. 
40. The goddess is figured in the numerous examples of the tonalamatl in the various codices, of which facsimiles are to be found in all important libraries.

4I. The Tonalamatl of the Aubin Collection. An Old Mexican Picture Manuscript in the Paris National Library. Published at the Expense of his Excellency the Duke of Loubat. With Introduction and Explanatory Text by Dr. Eduard Seler. Berlin and London, 1900-1901, p. I I5.

42. The Codex Borbonicus is in the National Library, Paris. It was published in exact facsimile, with an introduction by Dr. E. T. Hamy, Paris, 1899. The scene referred to is on $\mathrm{p}$. 18 of the Paris reproduction.

43. The important Codex Telleriano Remensis was published in facsimile, with an introduction by E. T. Hamy, by the Duke of Loubat, Paris, I 899 . The illustration referred to is on p. 22 verso, of the plates.

44. Seler, op. cit. (Note 4I), p. I I8.

45. Kingsborough, vol. vi, p. 129.

46. Sahagun, see reproduction of Troncoso, estampa x, fig. 34 .

47. Codex Borbonicus, p. I 8 .

48. Tonalamatl Aubin, op. cit., pl. I8.

49. Seler, op. cit., pp. I I $4^{-1}$ I 8 .

50. This quotation is from the Libro de Oro y Tesoro Indico, a precious manuscript in the library of the late Joaquín García Icazbalceta. Icazbalceta writes as follows about the author: "We do not know who was Fr. Andrés de Alcobiz, who in the year 1543 collected in Spain these laws of the Mexicans. It is published in Nueva Colección de Documentos para la Historia de México, tomo III, p. 3I3, Mexico, $189 \mathrm{r}$.

51. Saville, Goldsmith's Art in Ancient Mexico, p. II9.

52. Anonymous Conqueror, translated by Marshall $\mathrm{H}$. Saville, publication of the Cortes Society, no. I, pp. 65-67, New York, 1917.

53. Obras Históricas de Don Fernando de Alva Ixtlilxochitl, tomo I, Historia Chichimeca, cap. XxxvI, p. I80, published in Mexico in I 892 under the editorship of Dr. Alfredo Chavero.

54. We refer here to the labors of Mexican archeologists begun by Leopoldo Batres, and continued by Dr. Manuel Gamio. An elaborate work, edited by Gamio, treating of the exploration of this region, has just been printed in Mexico.

55. Sahagun, op. cit., tomo III, lib. I0, cap. $\mathrm{xxIx,} \mathrm{p.} 107$.

56. Ibid., tomo I, lib. 3, cap. XII, p. 255.

57. Saville, The Cruciform Structures of Mitla and Vicinity, Putnam Anniversary Volume, p. 187, New York, 1909. 
58. Relación de Andrés de Tapia, published for the first time by Icazbalceta in Colección de Documentos para la Historia de México, tomo II, pp. 582583, Mexico, I 866.

59. The Relación de Texcoco was written by Juan Bautista Pomar, a mestizo, and a grandson of the Texcocan king Nezahualpitzintli on his mother's side. It was composed for Philip II, and belongs to the class of Relations like those of Yucatan, etc. It was first published by Icazbalceta in his Nueva Colección de Documentos para la Historia de México, tomo II. The quotation is from p. 10.

60. Bernal Díaz, op. cit., vol. II, book vi, chap. xcii, p. 74 .

6r. Ibid., chap. Crv, p. I38.

62. Tezozomoc, op. cit., cap. LXxxvi, p. 592.

63. Ibid., cap. LxxxviI, p. 593.

64. Sahagun, op. cit., tomo I, lib. I, cap. XIII, p. I8.

65. Pomar, op. cit., pp. 8-9.

66. Seler, Altmexikanische Studien, Ein Kapitel aus dem Geschichtswerk des P. Sahagun. Sonderabzug der Veröffentlichungen aus dem Königlichen Museum für Völkerkunde, I, 4, p. I23, Berlin, I890.

67. Anonymous Conqueror, op. cit., p. 22.

68. Sahagun, op. cit., tomo III, lib. 8, cap. Ix, p. 289.

69. Antonio Peñafiel, Indumentaria Antigua Vestidos Guerreros y Civiles de los Mexicanos, pl. I49, Mexico, 1903.

70. The Codex Coxcatzin has been published in part by Eugène Boban in Documents pour Servir à l'Histoire du Méxique, Atlas, pl. 4I-45, Paris, I89I.

71. Tezozomoc, op. cit., cap. LXI, p. 469; cap. LXIX, pp. 506-507.

72. Diego Duran, Historia de las Indias de Nueva-España y Islas de Tierra Firme, tomo I, cap. LI, p. 407, Mexico, 1867.

73. Tezozomoc, op. cit., cap. CI, p. 659.

74. Anonymous Conqueror, op. cit., p. 22.

75. Thomas Unett Brocklehurst, Mexico To-day, pl. xxxiv, London, I883.

76. See Saville, Exploration of Zapotecan Tombs in Southern Mexico, American Anthropologist, N. s., vol. I, pp. 350-362, April, 1899; and Funeral Urns from Oaxaca, American Museum Journal, vol. Iv, pp. 49-69, New York, 1904.

77. Saville, Goldsmith's Art in Ancient Mexico, pp. 15I-I63, pl. i, viii.

78. Manuel Gamio, Los Monumentos Arqueológicos de las Inmediaciones de Chalchihuites, Zacatecas, sobretiro del tomo ir de los Anales del Museo Nacional de Arqueologia, Historia y Etnologia, pp. 467-492, 5 plans, 8 pl., 
Mexico, 19ro. This is the first piece of work by Gamio, and presents the results of the first important archeological exploration undertaken in this part of Mexico.

79. We have just received the first number (Jan.-Feb., I922) of tomo I, época $4^{\mathrm{a}}$, of the Anales del Museo Nacional de Arqueologia, Historia y Etnografia of Mexico, which have long been interrupted. In it is announced the forthcoming appearance of a paper relating to this subject, "Máscara con Mosaicos de Turquesas.-Dictámenes Periciales." It is to be hoped that the authenticity of this object will be cleared of all suspicion by the proposed study.

80. On this subject consult Saville, Precolumbian Decoration of the Teeth in Ecuador, etc., American Anthropologist, N. S., vol. I5, I9I3; reprinted as Contributions from the Heye Museum, vol. I, no. 2, 1913.

81. David Casares, A Notice of Yucatan with Some Remarks on its Water Supply, Proceedings of the American Antiquarian Society, pp. 207-230, Oct., 1905.

82. Diego de Landa, Historia de las Cosas de Yucatan, edition of Juan de Dios de la Rada y Delgado, p. 84, Madrid, I88I.

83. Casares, op. cit., p. 226.

84. William H. Holmes, Archeological Studies among the Ancient Cities of Mexico, Anthropological Series, Field Columbian Museum, vol. I, no. I, Chicago, I 895. Part I, Monuments of Yucatan, Section on Chichen Itza, p. I37.

85. Seler, Codex Vaticanus No. 3773. Elucidation published at the expense of the Duke of Loubat, Berlin and London, 1902-1903. In this study Seler treats at length of the God Xipe Totec.

86. Sahagun, op. cit., tomo I, lib. I, cap. XvIII, p. 28.

87. The two mosaic masks on the sculptured wall at Chichen Itza are taken from the drawings on pl. 46 and 47 of the great work of Alfred P. Maudslay published as part of Biologia Centrali-Americana: or Contributions to the Knowledge of the Fauna and Flora of Mexico and Central America, edited by F. Ducane Godman and Osbert Salvin. Archæology, vol. III (Plates). London, I895-1902. The crowns are from pl. 38, 49-59. The crown with the feathers is from the doorway column of Temple A, of the Ball Court.

88. The first extended study of Mexican turquois mosaics, based especially on some of the specimens now in the British Museum, was made by $\mathrm{E}$. T. Stevens and published in his Flint Chips, pp. 324-328, London, I870. Read's paper did not appear until 1895 .

89. See Maudslay's edition of Bernal Díaz, op. cit., vol. I, app., pp. 299-302. Maudslay gives photographs of the two wooden masks in the British Museum, which he calls "Masks of Quetzalcoatl," and of the skull mask which he denominates "Mask of Tezcatlipoca."

9o. See List of Works following. 
9I. See trąnslation in Saville, Goldsmith's Art in Ancient Mexico, pp. 126-127.

92. See List of Works following.

93. See List of Works following. Our illustration is a photograph of the colored lithographic plate of Uhle.

94. Zelia Nuttall, On Ancient Mexican Shields, Separat-Abdruck aus Internationales Archiv für Ethnographie, Bd. v, 2 I pp., Leiden, I 892.

95. Read, in his study, gives only a drawing of this shield. Our illustration, a direct photograph, does not show the designs so clearly as the drawing.

96. Our illustration is a copy of the photograph published by Heger. See List of Works following.

97. Seler, Codex Fejérváry, An Old Mexican Picture Manuscript in the Liverpool Free Public Museum, published at the Expense of His Excellency the Duke of Loubat, p. 2 I0, Berlin and London, I90I-I902.

98. The Codex Nuttall or Zouche was published by the Peabody Museum, Cambridge, in 1892 . The original is now in the British Museum.

99. On this subject consult the elucidations of Mexican codices by Seler, published at the expense of the Duke of Loubat. Also, Mexican and Central American Antiquities, Calendar Systems, and History, being translations from the German of papers by Seler, Förstemann, and others, published as Bulletin 28, Bureau of American Ethnology, Washington, 1904. The studies of C. P. Bowditch will be found in his Numeration, Calendar Systems and Astronomical Knowledge of the Mayas, Cambridge, Mass., I9IO.

100. Hermann Beyer, El llamado "Calendario Azteca," Mexico, I921, an important study of interpretation of the calendar stone of the Aztecs.

101. This specimen was first illustrated by Lehmann in his paper, Die altmexikanischen Mosaiken des Ethnographischen Museums in Kopenhagen, Globus, 1907. Our illustration is a drawing from the photograph reproduced in this study.

102. See Note ror.

103. See Heger, I892, in List of Works.

104. Our drawing is from the photograph published by Lehmann in his paper in the Proceedings of the Fifteenth International Congress of Americanists, Quebec, 1907.

105. Our drawing of this specimen is made from the illustration published by Oppel. See List of Works, I896.

106. Illustrations of this piece have just been published for the first time by Lehmann in his Altmexikanische Kunstgeschichte: Ein Entwurf in Umrissen, Berlin, I922(?).

107. See Seler's remarks to Heger's paper, List of Works, I890. 
108. Consult Seler, Altmexikanische Knochenrasseln, Gesammelte Abhandlungen, Zweiter Band, pp. 672-694, Berlin, 1904; also Lumholtz, Unknown Mexico, vol. II, pp. 428-430, New York, I902.

109. As Colini's paper is not easily consulted, we append his description of these three Mexican wooden objects:

"L'idolo, a guisa di figura umana, è alto m.o. 45 [173/4 inches high]. La testa è molto grande, senza alcuna proporzione con le altre parti del corpo ed è sormontana da un ornamento. La faccia conserva ancora traccie del rosso con cui era colorita, il naso è piccolo ma largo e schiacciato, gli occhi sono incavature ovali ed hanno sotto tre incisioni circolari, come se si fossero volute rappresentare le occhiaje di persona vecchia o malata. Anche vicino agli angoli della bocca, poco sopra, sono incise due linee oblique, riempite di bianco, quasi a guisa di rughe. Tiene le braccia sollevate con le mani sull'ornamento della testa, ma le altre parti del corpo non sono affatto distinte. Posa sopra una base decorata con incisioni colorite in bianco, di cui manca però una parte, cosicchè non è possibile comprendere pienamente la sua forma primitiva, la quale sembra che fosse rettangolare. In ogni modo era troppo sottile per sostenere l'idolo, e perciò dobbiamo credere che facesse parte di un apparecchio più complicato.

"Delle maschere l'una (v. Tav. in fine, fig. 2) nel tipo e nell'espressione somiglia a quella incrosta di mosaico, descritta da Ulisse Aldrovandi la quale oggi si conserva nel Museo Etnografico Nazionale di Roma [67/8 inches high]. Il naso è lungo, sottile ed arcuato; ma non essendo incavato nell'interno, la maschera non potrebbe adattarsi faccia. Gli occhi consistono in rozze aperture ovali, sotto le quali, a breve distanza, sono incisi due profondi solchi, a guisa di semicerchi, come nell'idolo. Intorno la fronte, sopra la radice del naso, corre una larga fascia in rilievo. Fra le labbra inferiore allungate, esce la lingua, che si ripiega sul mento: della parte inferiore non è possibile formarsi un concetto perchè è stata tagliata. Conserva qua e là le traccie della tinta rossa, ma sono meno evidenti che nell'idoli. Sulla fascia della fronte, nella lingua e sul naso possono ancora notarsi delle linee incise, riempite di materia bianca.

"L'altra maschera (tav., fig. I) è lavorata con maggiore cura [7 I/8 inches high]: ha la faccia simmetrica nelle varie parti e proporzionata. Le labbra sono piccole, ma, quello inferiore essendo rotto, non è possibile indovinarne la forma. Ha il naso arcuato, e largo alla base, ed è internamente incavato in modo che la maschera potrebbe adattarsi alla faccia, e siccome la bocca, le narici e gli occhi sono forati, cosi il portatore potrebbe benissimo vedere, respirare e parlare. Nella parte inferiore delle occhiaje, agli angoli, si notano due piccole incavature ad arco, la cui forma farebbe supporre che vi fossero adattati pezzi di madreperla a guisa di occhi, come in quelle del Museo Christy. In generale i lineamente mostrano quella espressione placida e contemplativa, che, secondo il Tylor, e caratteristica dei lavori aztechi e degli egiziani, tanto se si riguardano le massiccie sculture in pietra, quanto le piccole teste di terracotta. Ambedue queste maschere, nella parte superiore corrispondente alla fronte, hanno fori nei quali forse 
s'immettevano cordoncini per sospenderle: la prima ne ha due grandi agli angoli, l'altra quattro più piccoli intorno." (See note under List of Works, I885.)

I 10. D. I. Bushnell, Jr., Two Ancient Mexican Atlatls, American Anthropologist, N. S., vol. 7, no. 2, 1905; also North American Ethnographical Material in Italian Collections, ibid., vol. 8, 1906.

II I. See Note 94 .

I12. Fr. Toribio Motolinia, Historia de los Indios de Nueva España, Tratado Tercero, cap. Xx, pp. 247-249, edition published by Icazbalceta, Colección de Documentos para la Historia de México, tomo I, Mexico, 1858.

113. Consult Frederick Starr, The Little Pottery Objects of Lake Chapala, Mexico, Bulletin II, Department of Anthropology, University of Chicago, Chicago, 1897.

II4. An important summary of these discoveries has recently been published by Gamio; see Las Excavaciones del Pedregal de San Angel y la Cultura Arcaica del Valle de Mexico, American Anthropologist, N. s., vol. 22, no. 2, 1920. Also the paper of Hermann Beyer, Sobre Antigüedades del Pedregal de San Angel, Memorias de la Sociedad Cientifica "Antonio Alzate" de México, tomo 37, núm. 8, Oct., I9r7; and Ramon Mena, El Hombre de "El Pedregal" de San Angel, Escuela Nacional, Preparatoria Curso de I 918. 


\section{LIST OF WORKS DESCRIBING MEXICAN MOSAICS}

\section{8}

Aldrovanus, Ulysses. Musæum metallicum. Bologna.

In this work are a brief description (p. 550) and illustrations of two of the specimens now in the Museum in Rome, namely, one of the knife handles (our pl. $\mathrm{xxxIx}$ ), and the mask (our pl. virI). This book is vol. XIII of the fourteen volumes of the Opera Omnia of Aldrovanus, issued in 1602-1668.

\section{r86r}

Tylor, E. B. Anahuac: or Mexico and the Mexicans, ancient and modern. London.

See pp. I ro, 235, 337-339, I fig. Dr. Tylor illustrates the knife with handle in the figure on p. IoI. In the appendix (pp. 337-339), article V is a "Description of three very rare specimens of ancient Mexican mosaic work (in the collection of Henry Christy, Esq.)." These objects are now in the British Museum.

\section{6}

Brasseur de Bourbourg, E., and Waldeck, F. Palenque et autres ruines de l'ancienne civilisation du Mexique. Collection de vues, bas-reliefs, morceaux d'architecture, coupes, vases, terrecuites, cartées et plans, dessinés d'après nature et relevés par $\mathbf{M}$. de Waldeck. Texte rédigé par M. Brasseur de Bourbourg . . . Ouvrage publié sous les auspices de S. E. M. le Ministre de l'instruction publique. Paris. Arthur Bertrand, Editeur. Plates. Monuments anciens du Mexique.

Describes (p. vIII) and illustrates in color (pl. XLIII, XLIV) the mosaichandled knife and mosaic skull mask formerly in the Hertz collection, now in the British Museum.

\section{7}

LÉouzon le DUC, L. Rapport sur les antiquités mexicaines conservées à Copenhague. Archives de la Commission Scientifigue du Mexique, Tome III. Paris.

Two Mexican mosaics in the Copenhagen Museum are described (tome III, pp. $157-158)$, as follows: 
"Voici maintenant trois pièces qui, à mon avis, méritent une attention toute particulière.

"D'abord, une tête d'alligator, de 19 centimètres de longueur. Cette tête est sculptée en bois et creusée par derrière. La gueule de l'alligator est largement ouverte et ses mâchoires encadrent une tête humaine fixée au fond du palais.

"Ensuite, une tête d'idole, également sculptée en bois et évidée intérieurement, a vec une coiffure très-élevée et évasée au sommet, d'une hauteur totale, y compris la tête, de 24 centimètres. La bouche de l'idole est vaste, ses lèvres fortement tendues découvrent une double rangée de longues dents; ses oreilles sont ornées de pendelogues.

"Ces deux pièces offrent cette singularité remarquable qu'elles sont garnies en partie, et ont dû l'avoir été en entier, de petits fragments d'os la plupart quadrangulaires, blanc ou teints en vert, en rouge et en noir, fixés sur le bois à l'aide d'une espèce de résine, ce qui leur donne l'aspect d'une mosaïque. Fort endommagées, elles n'ont guère conservé d'intacts que les yeux, dont les prunelles sont formées d'os blancs, noirs et rouges, et entourées d'un cordon d'os verts. L'état du bois qui les compose suffrirait à lui seul pour établir leur haute antiquité, si déjà leur caractère symbolique ne la rendait évidente. L'une et l'autre ont été achetées à Rome, où l'on suppose qu'elles avaient été apportées de Mexico par un missionnaire."

\section{9}

SQuier, E. G. Observations on a collection of chalchihuitls from Central America. Annals of the New York Lyceum of Natural History, vol. IX, August, article XIV, pp. 252-253, fig. I.

The mosaic skull in the British Museum is illustrated, after Waldeck.

\section{0}

Stevens, Edward T. Flint chips. A guide to prehistoric archæology, as illustrated by the collection in the Blackmore Museum, Salisbury. London.

Aztec mosaic work, pp. 324-328. Describes specimens in the Christy collection.

\section{0}

Steinhauer, C. L. Das Königliche Ethnographische Museum zu Copenhagen. Hand-catalog für die Besuchenden. Copenhagen.

Describes (p. 19) the two mosaics in the Copenhagen Museum. In the 1866 edition the description is on p. 22.

\section{3}

Brocklehurst, Thomas Unett. Mexico to-day: a country with a great future, and a glance at the.prehistoric remains and antiquities of the Montezumas. London. 
Describes (p. I84) and reproduces in colors (pl. XxxiII) the human-skull mask in the British Museum. Pl. xxxiv illustrates the goddess Coatlicue, showing the turquois-mosaic in colors-the specimen to which Peñafiel refers, vide 1903. See our pl. II.

\section{5}

Colini, G. A. Collezioni etnografiche del Museo Borgiano. Bollettino della Società Geografica Italiana, Roma, Anno XIX, vol. XXII; serie II, vol. X, pp. 3I6-325, 9I4-932.

In this article Colini (pp. 324-325) describes two masks and an idol in the Museo Borgiano in Rome. Regarding these specimens he quotes from Vitæ Synopsis Stephani Borgiæ, S. R. E. Cardinalis amplissimi, S. Congr. de Propaganda Fide Præfecti, Roma, I805, p. 44, "Classis mexicana: multa lignea et testacea idolorum simulacra forma et figura singulari, ac gente mexicanæ propia." He describes the idol as being made of wood in the form of a human figure, $45 \mathrm{~cm}$. high. The two masks of wood are described, and figured on the plate containing drawings of other American antiquities. It is highly probable that these three objects were formerly decorated with mosaic.

Pigorini, Luigr. Gli antichi oggetti Messicani incrostati di mosaico esistenti nel Museo Preistorico ed Ethnografico di Roma. Reale Accademia dei Lincei, Anno CCLXXXII, I884-I885. 9 pp., I pl. with 5 colored figs.

Bastian, A. Zwei altmexikanische Mosaiken. Verhandlungen der Berliner Gesellschaft für Anthropologie, p. 201.

1888

Bastian, A., and Uhle, Max. Schädelmaske von Mexico und Analogien aus der Südsee. Veröffentlichungen aus dem Königlichen Museum für Völkerkunde, Herausgegeben von der Verwaltung, Berlin, Oct.

A description (pp. 2-3) and colored illustration (T. I., I) of the mosaicskull mask in the Berlin Museum.

ANDREe, Richard. Die altmexikanischen Mosaiken. Beitrage zur Ethnographie von Amerika aus dem Internationalen Archiv für Ethnographie. Leiden.

Brief notice (p. 8) of the specimen in Gotha.

\section{9}

ANDREe, Richard. Ethnographische Parallelen und Vergleiche. Neue Folge. Leipzig.

Description (pp. 127-130) of the mosaic specimen in Gotha. 
1890

Peñafiel, Antonio. Monumentos del arte Mexicano antiguo. Berlin.

Description (Text, p. 23) and illustration in colors (Atlas, pl. 123) of the knife with mosaic handle in the British Museum.

AndReE, Richard. Sur une ancienne mosaique mexicaine. Congrès International des Américanistes, Compte-rendu de la septième session, Berlin, I888. Berlin.

Describes the Gotha specimen (pp. 146-I48).

Heger, Franz. Sur quelques objets archéologiques du Mexique et de l'Amérique du Sud. Congrès International des Américanistes, Compte-rendu de la septième session, Berlin, 1888, pp. 93-97.

The author describes (p. 94) one of the mosaic pieces in the Vienna Museum. In the discussion of this paper, Seler (p. 104) identifies the animal-like figure as representing the god Xolotl.

\section{2}

Pi y Margil, Francisco. Historia de la América antecolombiana. Tomo primero, segunda parte. Barcelona.

Two colored illustrations (opposite p. 1214) of the mosaic-handled knife in the British Museum.

Heger, Franz. Altmexikanische Reliquien aus dem Schlosse Ambras in Tirol. Annalen des K. K. Naturhistorischen Hofmuseums, B. viI, Heft 4, pp. 310-400, pl. XVIII, XxII. Vienna.

In this paper Dr. Heger describes and illustrates the shield and animal head (three views) of turquois mosaic in the Vienna Museum.

\section{5}

Read, Charles Hercules. On an ancient Mexican head-piece coated with mosaic. Archreologia, vol. LIV, I6 pp., pl. XXVIII, fig. I-6, London.

Gives in colors and describes for the first time the mosaic head-piece, and illustrates all but one of the eight other pieces, in the British Museum.

\section{6}

Oppel, A. Die altmexikanischen Mosaiken. Globus, Bd. Lxx, Nr. I (June), pp. 4-12, 15 fig., Braunschweig.

Figures seven mosaic pieces in the British Museum, five pieces in Rome, one piece in Berlin, a piece in Gotha, and a section of the shield in Vienna. 
1903

Peñafiel, Antonio. Indumentaria Antigua Mexicana. Vestidos Guerreros y Civiles de los Mexicanos. Mexico.

Dr. Peñafiel, in chapter xxIII, under the heading "Incrustaciones de Mosaico," describes some of the mosaic pieces in Europe which he states are the most important specimens. "Of this class of works the Museo Nacional (Mexico) can count as having only one, in the statue of Coatlicue coming from Tehuacan." On pl. 26 are given the British Museum knife, and the two knife-handles in Rome; on pl. 117 one of the masks in Rome; on pl. I18(A) the skull mask in Berlin, and (B) the mask in Rome; pl. 123 is the femur musical instrument in Rome; and pl. 168 restorations of the knife-handle specimens with blades, in Rome. These illustrations are all in colors, excepting the last.

\section{6}

Bushnell, David I., Jr. North American ethnographical material in Italian museums. American Anthropologist, N. S., vol. viII, Lancaster, $\mathrm{Pa}$.

On pp. 245-246 the author briefly describes the five mosaic pieces in Rome, and regarding one of the masks (our pl. viI, a) quotes from the inventory of the Guardaroba Medicea, 1553, showing the specimen to have been in the Medici collection.

Lefmann, Walter. Altmexikanische Mosaiken und die Geschenke König Motecuzomas und Cortés. Globus, Bd. XV, Nr. 20, pp. 318-322, Braunschweig, 29 Nov.

In this study Lehmann enumerates the twenty-three Mexican mosaic pieces in European museums and gives considerable documentary material from the early chroniclers.

\section{7}

Kunz, George Frederick. Gems and precious stones of Mexico. Mexico.

On pp. 7-10, Dr. Kunz discusses turquois and describes some of the turquois mosaic specimens in European museums. On p. $5^{2}$ he concludes that "it must be considered as possible, at least, that other localities containing turquois were once known, and may be hereafter re-discovered."

Lehmann, Walter. Altmexikanische Mosaiken in Kgl. Museum für Völkerkunde zu Berlin. Congrès International des Américanistes, $X V^{e}$ Session, tenue à Quebec en Igo6, tome II, pp. 339-349, 4 fig., Quebec.

Describes and illustrates two pieces of Mexican mosaics in the Ethnographical Museum of Berlin, a double-jaguar figure, and a jaguar head. The first came 
from the estate of Alexander von Humboldt, the second was transferred to the Berlin Museum from the Ducal Museum of Braunschweig.

Lehmann, Walter. Die altmexikanischen Mosaiken des Ethnographischen Museums in Kopenhagen. Globus, Bd. XCI, Nr. 21, pp. 332-335, 6 June, I907. Abb. I-III.

The author describes and figures the two pieces in Copenhagen, giving front and side views, and two different drawings of one of the masks in Rome.

\section{8}

Díaz del Castilio, Bernal. (Maudslay, A. P., translator and editor.) The true history of the conquest of New Spain. Edition of the Hakluyt Society, vol. I, London.

Under the title "Montezuma's Gifts to Cortés," Maudslay describes (Appendix, pp. 299-302) and illustrates (pl. 13-16) the three mosaic masks in the British Museum. Pl. 16 is a rear view of the skull mask showing the leather strap by which it was attached to the head. This mask Maudslay identifies as probably that of Tezcatlipoca, and the other two as belonging to Quetzalcoatl.

I9IO

Gamio, Manuel. Los monumentos arqueológicos de las inmediaciones de Chalchihuites, Zacatecas. Anales del Museo Nacional de Arqueologia, Historia y Etnologia, tome II, pp. 469-492, pls. I-8, Mexico.

On pl. 8 are figured two pieces of mosaic-work found in the ruins near Chalchihuites.

Blackiston, A. Hooton. Recent discoveries in Honduras. American Anthropologist, N. S., vol. 12, Lancaster, Pa.

Describes (p. 539) and illustrates (pl. xLvI) the mosaic wooden mask found in 1908 in a cave in an arroyo on the headwaters of a small stream flowing into the Rio Chamelecon, about 25 miles distant from the ruins of the ancient city of Naco. This specimen is now in the Museum of the American Indian, Heye Foundation. See our pl. xvII

\section{2}

Joyce, T. A. A short guide to the American antiquities in the British Museum. London.

Joyce describes (p. I4) and illustrates (figs. 12-17) six of the mosaic pieces in the British Museum. 
I9I4

Joyce, T. A. Mexican archæology. An introduction to the archæology of the Mexican and Mayan civilizations of pre-Spanish America. New York and London.

In pl. I is reproduced in colors the skull mask, and in pl. xviII, fig. I, the knife with handle. Reference to these is made on p. I4I.

Holmes, W. H. Masterpieces of aboriginal American art. II. Mosaic work, minor examples. Art and Archœology, vol. I, no. 3, Washington, November.

A description (pp. 91-102) of some of the more important specimens of mosaics, with colored frontispiece and 9 figures.

\section{I9I5}

Pogue, Joseph E. The turquoise. A study of its history, mineralogy, geology, ethnology, archæology, mythology, folklore, and technology. Memoirs of the National Academy of Sciences, vol. XII, part II, third memoir, Washington.

Mexican mosaics are described on pp. 93-97; fig. 4 illustrates the bird mask in Gotha; pl. 15-17, Mexican mosaics in the British Museum and in Rome (Io pieces). The Use of Turquois in Mexico and Central America: Use as Attested by Historical Evidence, pp. 90-92; Use as Attested by Objects, pp. 93-97.

\section{1}

Arreola, José María. Como legítima el Museo Nacional ha adquirido una pieza falsificada. El Excelsior, Mexico, Oct. 20.

Illustrates in this signed newspaper article a stone mask with turquois mosaic decoration said to have been found in Guerrero. He concludes that it is fraudulent.

Lehmann, Walter. Altmexikanische Kunstgeschichte ein Entwurf in Umrissen. Band 8 des Orbis Pictus. Weltkunst-Bücherei herausgegeben von Paul Westheim. Berlin.

In this short study of old Mexican art history Dr. Lehmann illustrates a number of notable Mexican antiquities. The Xolotl figure in Vienna is illustrated, front and side views, pl. 7 , and the crouching animal figure in the British Museum is given on pl. 8 . He gives brief descriptions in the description of plates on pp. 22-23. 


\section{2}

Gamio, Manuel. Una máscara de mosaico falsificada. [A counterfeit mosaic mask.] Ethnos, tomo I, núms. 8-I2, pp. 260-264, Mexico, Nov. 1920-Mar. I921.

Gamio denounces as fraudulent the stone mosaic mask claimed to have been discovered in Guerrero by Porfirio Aguirre.

Mena, Ramon. La arqueología debe de estar en manos de arqueológicos. El Universal, Mexico, April 2.

In this signed newspaper article Mena defends the authenticity of the stone mask decorated with turquois mosaic, said to have been found in Guerrero. 



